\title{
Characterization Activities Conducted at the 183-DR Site in Support of an In Situ G aseous Reduction Demonstration
}

\author{
E. C. Thornton, Project Manager \\ T. J Gilmore \\ K. B. Olsen \\ R. Schalla \\ K. J. Cantrell
}

March 2001

Prepared for the U.S. D epartment of Energy under Contract DE-AC06-76RL01830 


\title{
DISCLAIMER
}

This report was prepared as an account of work sponsored by an agency of the United States Government. Neither the United States Government nor any agency thereof, nor Battelle Memorial Institute, nor any of their employees, makes any warranty, express or implied, or assumes any legal liability or responsibility for the accuracy, completeness, or usefulness of any information, apparatus, product, or process disclosed, or represents that its use would not infringe privately owned rights. Reference herein to any specific commercial product, process, or service by trade name, trademark, manufacturer, or otherwise does not necessarily constitute or imply its endorsement, recommendation, or favoring by the United States Government or any agency thereof, or Battelle Memorial Institute. The views and opinions of authors expressed herein do not necessarily state or reflect those of the United States Government or any agency thereof.

\author{
PACIFIC NORTHWEST NATIONAL LABORATORY \\ operated by \\ BATTELLE \\ for the \\ UNITED STATES DEPARTMENT OF ENERGY \\ under Contract DE-AC06-76RL01830
}

Printed in the United States of America

$$
\begin{aligned}
& \text { Available to DOE and DOE contractors from the } \\
& \text { Office of Scientific and Technical Information, } \\
& \text { P.O. Box 62, Oak Ridge, TN 37831-0062; } \\
& \text { ph: (865) 576-8401 } \\
& \text { fax: (865) 576-5728 } \\
& \text { email: reports@adonis.osti.gov }
\end{aligned}
$$

\footnotetext{
Available to the public from the National Technical Information Service, U.S. Department of Commerce, 5285 Port Royal Rd., Springfield, VA 22161 ph: (800) 553-6847 fax: $(703) 605-6900$

email: orders@ntis.fedworld.gov

online ordering: http://www.ntis.gov/ordering.htm
} 


\section{Characterization Activities Conducted at the 183-DR Site in Support of an In Situ Gaseous Reduction Demonstration}

E. C. Thornton, Project Manager

T. J Gilmore

K. B. Olsen

R. Schalla

K. J. Cantrell

March 2001

Prepared for

the U.S. Department of Energy

under Contract DE-AC06-76RL01830

This work is funded by the Office of Science and Technology, within the U.S. Department of Energy's Office of Environmental Management, under the Subsurface Contaminants Focus Area

Pacific Northwest National Laboratory

Richland, Washington 99352 


\section{Summary}

In Situ Gaseous Reduction (ISGR) is a technology currently being developed by the U.S. Department of Energy for the remediation of soil waste sites contaminated with hexavalent chromium, $\mathrm{Cr}(\mathrm{VI})$. This approach involves the injection of a treatment gas mixture into a subsurface zone of contamination, resulting in the reduction and immobilization of chromium. The primary beneficial result of treatment is the elimination of a vadose zone source of contamination, thus potentially leading to the decline in hexavalent chromium concentration levels in local groundwater.

Prior work suggests that a candidate for application of this approach is the 183-DR site at Hanford, which is associated with a significant groundwater contaminant plume and was formerly a water treatment facility that utilized chromate as a corrosion inhibitor. This document presents the data collected during the excavation of trenches and the drilling of two vadose zone boreholes (C3040 and C3041) at the 183-DR site to obtain information regarding distribution of hexavalent chromium and other chemical and geological data that could support an ISGR demonstration. Laboratory geotechnical and treatment tests were also conducted to obtain information needed to support the design of an ISGR demonstration, if undertaken at the site.

Sediment samples obtained from the trenches and from nearly continuous split spoon cores from the boreholes were submitted for physical and chemical analysis. Although elevated total chromium was detected in sediment collected from one of the trenches and from the first borehole (C3040) at $68 \mathrm{ft}$ depth, only trace levels of hexavalent chromium were detected in all other sediment samples. Hexavalent chromium was detected at elevated levels in groundwater samples obtained from the boreholes, as was expected. It is concluded that the two boreholes missed the vadose zone contaminant source that is responsible for the hexavalent chromium groundwater plume located downgradient of 183-DR. The welldefined nature of the groundwater plume suggests that an active vadose zone source may still exist in the vicinity of 183-DR, however. Borehole C3040 was completed as groundwater monitoring well 199-D2-8, which will help further define the upgradient configuration of the plume.

Further work is needed before a vadose zone source for the groundwater plume can be identified. The installation of additional groundwater wells in the vicinity of 183-DR could help to define the source. Split spoon core should be obtained from the vadose zone during the drilling of these wells and sediment samples collected and analyzed for hexavalent chromium. The chromate transfer lines and drain lines may also be sources of hexavalent chromium contamination. If a region of hexavalent chromium is identified at 183-DR, local excavation activities could be undertaken to define the source of contamination and potentially remove it. If contamination extends to significant depths, In Situ Gaseous Reduction can then be utilized for vadose zone treatment. 


\section{Acknowledgments}

This work is funded by the Office of Science and Technology, within the U.S. Department of Energy's Office of Environmental Management, under the Subsurface Contaminants Focus Area. The authors wish to acknowledge the contributions of a number of individuals who participated in or supported the preparation of this document: Bill Bonner, Jim Bush, Joe Devary, Mark Freshley, John Fruchter, Mart Oostrom, and Bruce Williams of Pacific Northwest National Laboratory; Ron Jackson, Greg Mitchem, and Scott Petersen of Bechtel Hanford Inc.; and Jim Hanson, Scott McMullin, and Arlene Tortoso of the U.S. Department of Energy. 


\section{Contents}

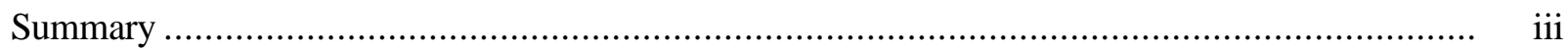

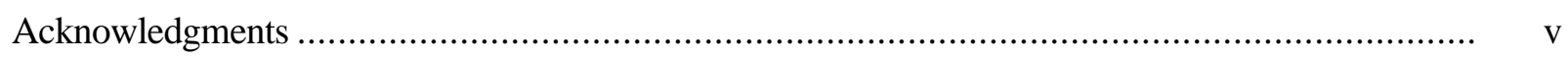

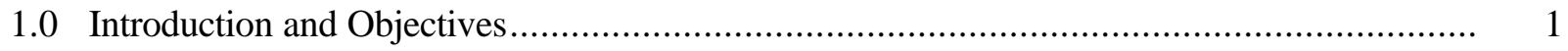

2.0 Summary of Site Characterization Activities.......................................................... 3

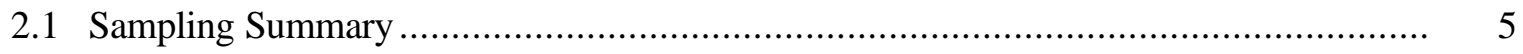

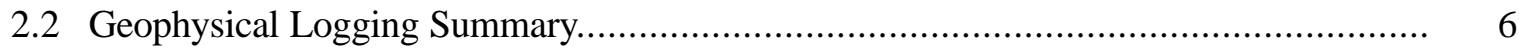

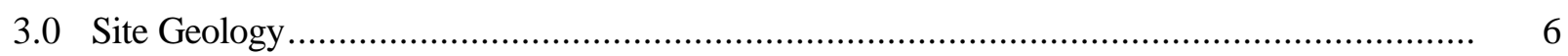

4.0 Vadose Zone Sediment Chemistry and Physical Properties ....................................... 9

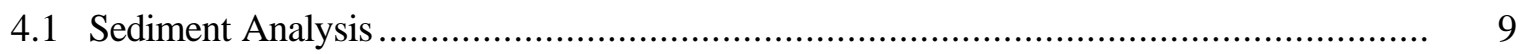

4.2 Moisture Content Measurements ........................................................... 10

4.3 Grain Size Analyses and Estimation of Vadose Zone Permeability .......................... 11

5.0 Groundwater Chemistry and Well Development ............................................ 12

5.1 Groundwater Chemistry Summary .......................................................... 13

5.2 Well Development Activities .............................................................. 13

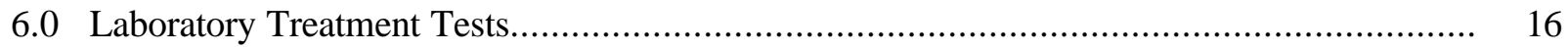

7.0 Conclusions and Recommendations ............................................................ 18

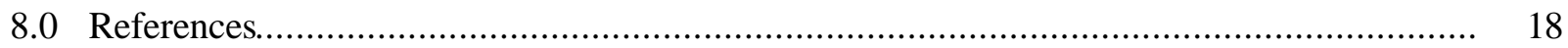

Appendix A - Well Construction Summary Report and Borehole Log for Borehole C3040 .......... A.1

Appendix B - Well Construction Summary Report, Borehole Log, and Geophysical Logs for Borehole C3041 ................................................................................... B. 1

Appendix C - Sediment and Groundwater Sampling and Analysis for 183-DR Boreholes

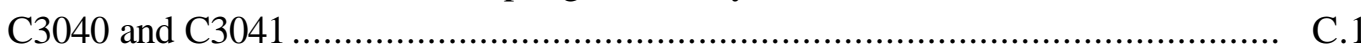




\section{Figures}

1 Conceptual Model of the In Situ Gas Treatment System and Wellfield Network ................. 2

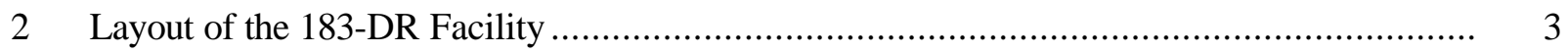

3 Location of Boreholes C3040 and C3041 and Excavation Trenches .............................. 4

4 Generalized Geologic Logs and Cr Concentration versus Depth for Borehole C3040

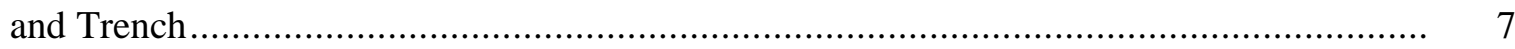

$5 \quad$ Generalized Geologic Logs and Cr Concentration versus Depth for Borehole C3041 ............ 8

6 Grain Size Distributions of Less than 3/8 inch Fraction of Excavated Sediment Samples ....... 12

7 Facilities and $\mathrm{Cr}$ (total) Groundwater Plumes in the 100-D Area in mid-Calendar

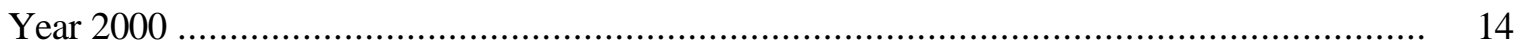

$8 \mathrm{Cr}(\mathrm{VI})$ Concentration in Development Water from Boreholes C3040 and C3041 „.............. 15

\section{Tables}

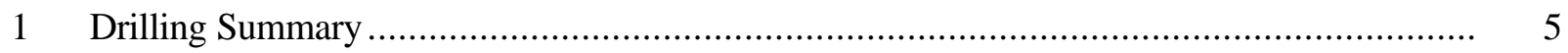

2 Moisture Content of Sediment Samples Collected from Boreholes C3040 and C3041 .......... 10

3 Weight Percent of Size Fraction Greater and Less than 3/8 inch for Excavated Sediment

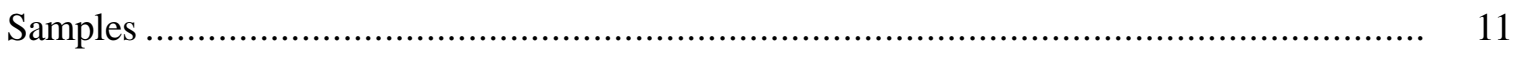

4 Sieve Analyses of Less than 3/8 inch Fraction for Excavated Sediment Samples ................. 11 


\subsection{Introduction and Objectives}

This document describes field activities associated with excavation of trenches and installation of two boreholes to evaluate the distribution of hexavalent chromium, $\mathrm{Cr}(\mathrm{VI})$, in the vadose zone at the former location of the 183-DR facility in the 100-D/DR Area of the U.S. Department of Energy (DOE) Hanford Site, Washington. If a source of contamination can be identified in the vadose zone at 183-DR, treatment by injection of a reactive gas has been proposed, which would chemically reduce hexavalent chromium (Thornton et al. 2000a). This approach to remediation is referred to as In Situ Gaseous Reduction or ISGR (see Figure 1). The ISGR technology is expected to have a significant beneficial effect on local groundwater by immobilizing chromium in the vadose zone and thus eliminating the source responsible for contamination of the unconfined aquifer.

The 183-DR facility was constructed in 1950 to treat water from the Columbia River that was used for cooling water in the 100DR Reactor (WHC 1993). Primary treatment operations included coagulation/flocculation of sediment and chlorination (Figure 2). This facility stockpiled sodium dichromate solution, which was delivered by rail to a dichromate transfer station and transferred to 183-DR by chemical lines. Sodium dichromate was added to the processed cooling water as a corrosion inhibitor (Richards 1953) at concentrations of several parts per million (ppm or mg/l) after filtering and before going into clear wells. The treatment plant was decommissioned in 1978. This involved removal of surface structures and filling the sedimentation basins with debris and backfill. No significant contamination of soil by hexavalent chromium was described in historical reports. A large groundwater chromate plume presently exists downgradient of the 183-DR site, however, suggesting that the area around 183-DR is the source of the plume (Rohay et al. 1999, Thornton et al. 2000a). Thus, if a vadose zone source of hexavalent chromium can be identified and treated at 183-DR, it is anticipated that the groundwater plume will eventually dissipate.

The development and deployment of the ISGR technology has been funded by the U.S. Department of Energy's Office of Science and Technology Subsurface Contaminant Focus Area under Technical Task Plan (TTP) RL38SS42, In Situ Chemical Treatment of Soils by Gaseous Reduction, to Pacific Northwest National Laboratory (PNNL). This approach involves the preparation of the reactive gas mixture (diluted hydrogen sulfide in air or nitrogen) by a skid-mounted gas treatment system and injection of the treatment gas into chromate-contaminated soil through a borehole, as illustrated in Figure 1. The mixture is drawn through the soil by a vacuum applied to extraction wells situated at the periphery of the flow cell. As the gas mixture contacts the contaminated soil, hexavalent chromium is reduced to the trivalent oxidation state, which results in immobilization and detoxification of the chromium. Residual hydrogen sulfide is then scrubbed from the extracted gas mixture by the gas treatment system.

A small-scale field demonstration of this approach was previously completed by PNNL at a waste site located at the U.S. Department of Defense (DOD) White Sands Missile Range, New Mexico (Thornton et al. 1999). This pilot demonstration was effective in treating hexavalent chromium at the test site and was successfully completed without any measurable release of treatment gas to the environment. 


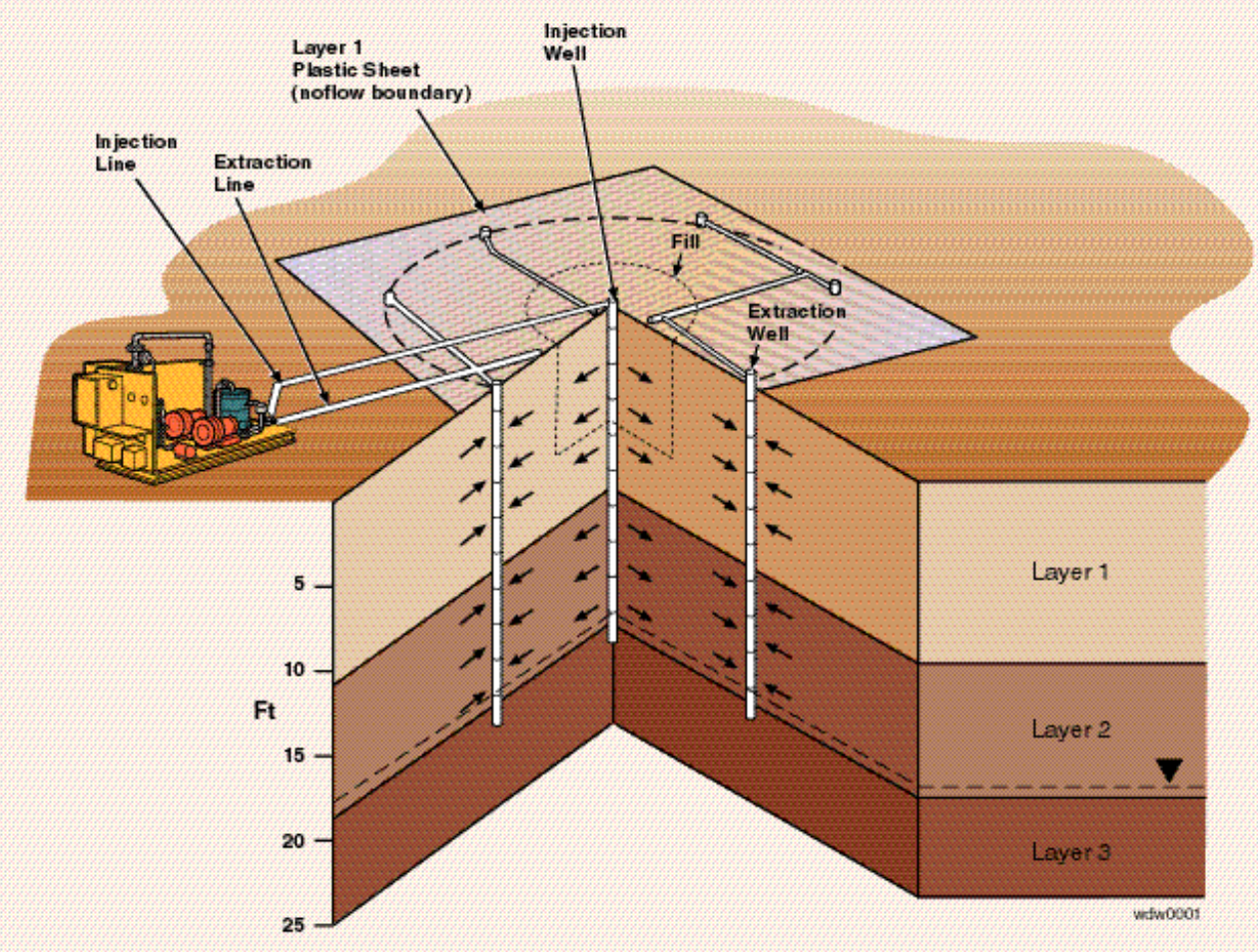

Figure 1. Conceptual Model of the In Situ Gas Treatment System and Wellfield Network

A larger scale demonstration of the ISGR technology within the 100 Areas at the Hanford Site could be utilized to support DOE's remediation goals and would represent the initial deployment of the ISGR technology at a DOE site. The need for the ISGR technology at the Hanford Site is formally recognized in Site Technology Coordinating Group (STCG), Need \#RL-SS11, Cost-Effective, In Situ Remediation of Hexavalent Chromium in the Vadose Zone. The ISGR approach to soil remediation has been presented to stakeholders in meetings with the Hanford STCG and the performance of a treatability test at the Hanford Site has been endorsed by the STCG Management Council, provided a suitable demonstration site can be identified. A draft treatability test plan has also been prepared that describes technical activities and requirements associated with the gas treatment demonstration if it is undertaken. ${ }^{1}$

${ }^{1}$ Thornton, E.C., K.B. Olsen, T.J Gilmore, R. Schalla, K. Cantrell, S.W. Petersen, and M. Oostrom. 2000. Treatability Test Plan for In Situ Gaseous Reduction at the Hanford 183-DR Site. Unpublished report, Pacific Northwest National Laboratory, Richland, Washington. 


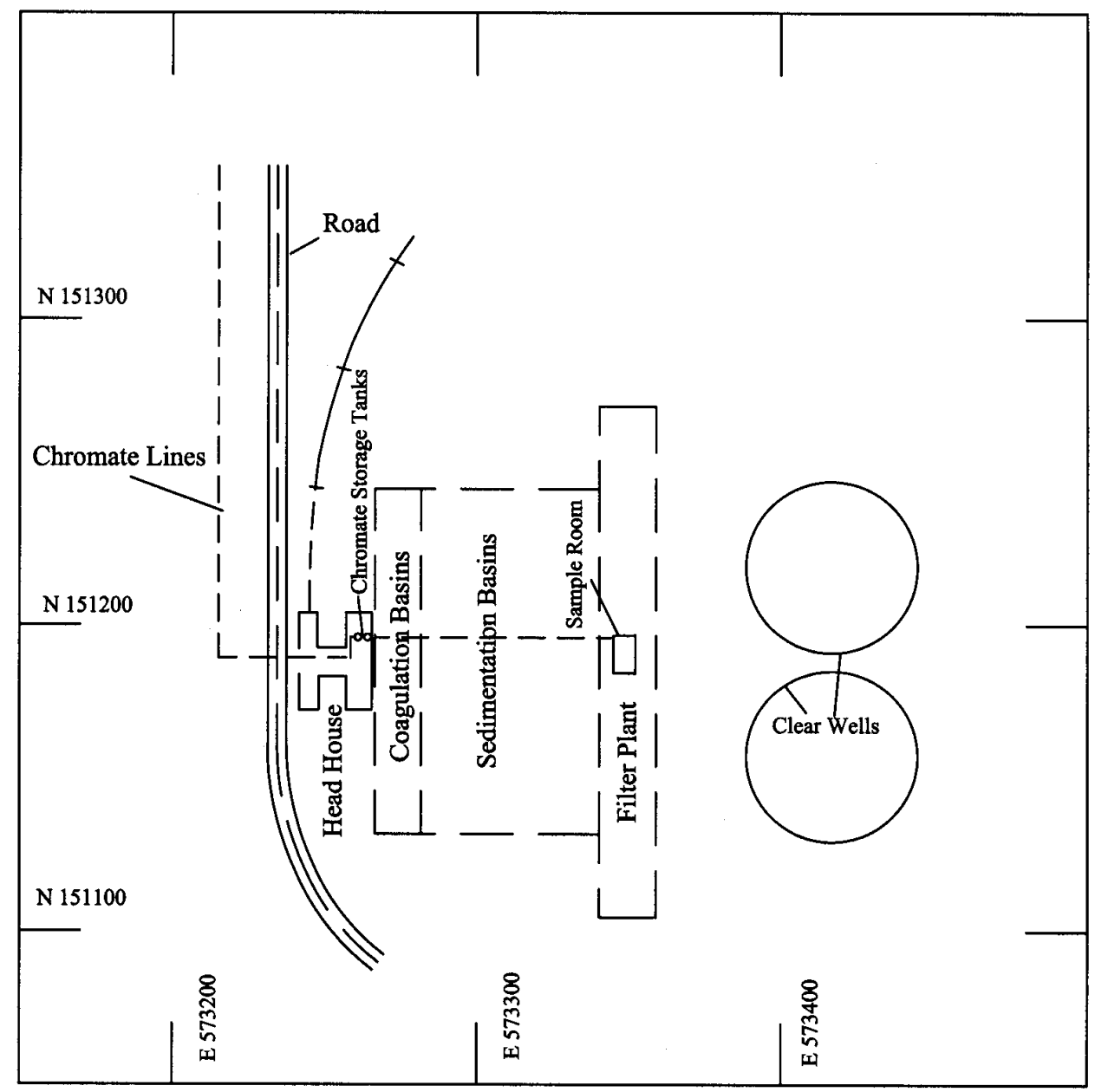

Figure 2. Layout of the 183-DR Facility. Coordinate System: State Plane NAD83 (meters).

English units are used in this report because they are used by drillers and geologists to measure and report depths and well construction details. The conversion to metric can be made by multiplying feet by 0.3048 to obtain meters or by multiplying inches by 2.54 to obtain centimeters.

\subsection{Summary of Site Characterization Activities}

Vadose zone characterization has been undertaken recently at 183-DR using Geoprobe ${ }^{\mathrm{TM}}$ and cone penetrometer equipment and by track hoe trenching (Thornton et al. 2000b). This work provided shallow ( $\leq 20$ feet) stratigraphic information, but very little hexavalent chromium contamination was identified. However, minor levels of hexavalent chromium and high levels of total chromium $(\sim 650 \mathrm{ppm})$ were 
detected in soil samples collected in a trench on the northeastern corner of the head house and just north of the chromate storage tanks (see Figures 2 and 3). This area was characterized by soil discoloration (i.e., a slightly orange coloration suggestive of oxidation).

The characterization approach utilized in the evaluation of hexavalent chromium in the vadose zone at 183-DR by borehole drilling has been presented in a drilling description of work (DOW) prepared by PNNL (Thornton et al. 2000a) and implemented under a Bechtel Hanford Inc. drilling contract. The area of contamination north of the 183-DR head house was identified as the location for the first exploration borehole (C3040; Figure 3) needed to determine if hexavalent chromium contamination is present deeper in the vadose zone at 183-DR. Secondary drilling options specified by the DOW included a location near the former 183-DR filter plant and a location near a bend in the chromate chemical lines to the west of the 183-DR head house. Based on the results of drilling borehole C3040, which suggested that the source could be located downgradient of C3040, it was determined to drill the second borehole, C3041, near the bend in the chromate chemical lines (Figure 3). A detailed discussion of the criteria employed in determining the location of the second borehole is presented in the DOW. The DOW also indicated that geophysical logging would be performed in one of the boreholes.

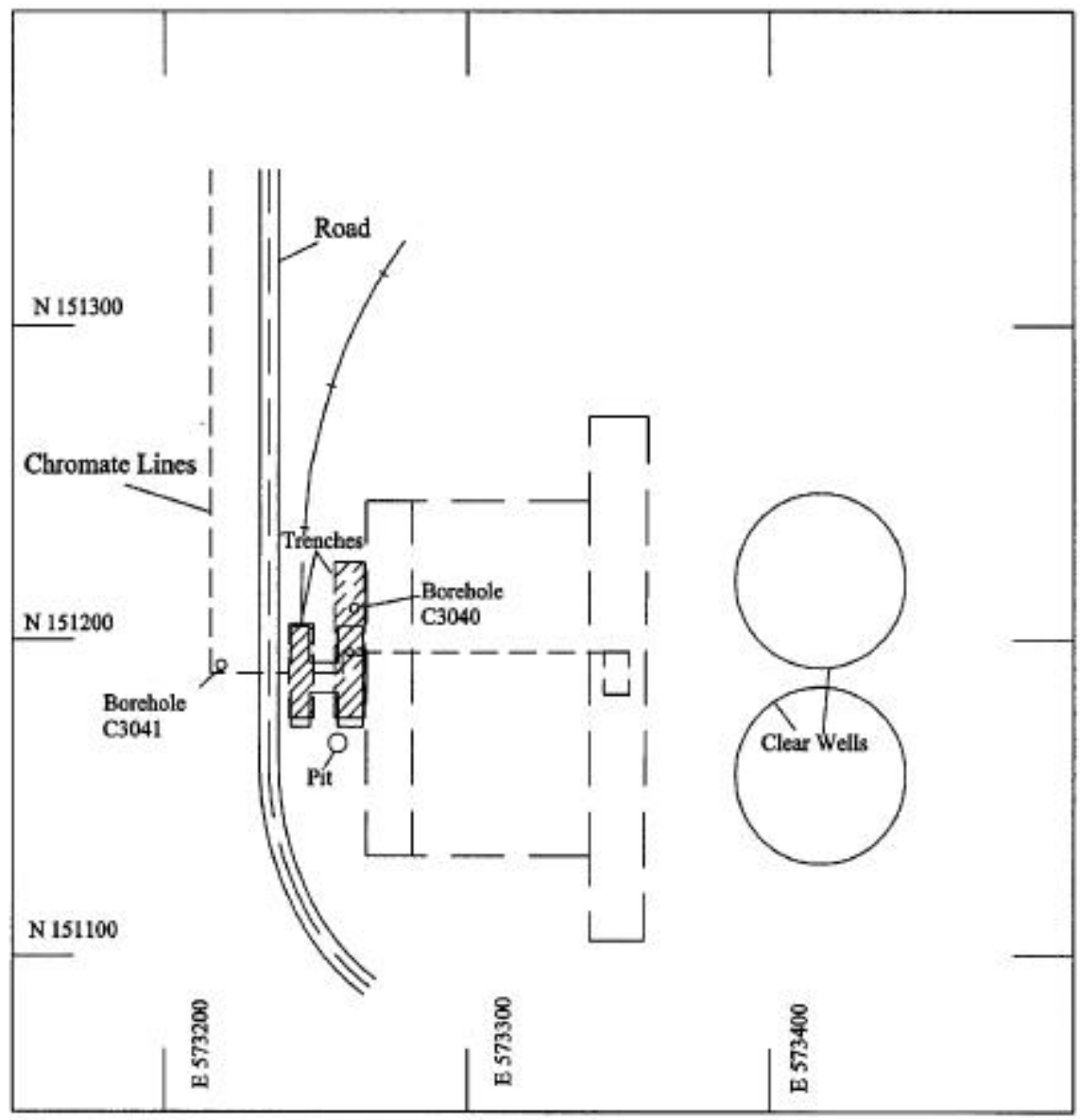

Figure 3. Location of Boreholes C3040 and C3041 and Excavation Trenches 


\subsection{Sampling Summary}

The top 20 feet of sediment was sampled in the vicinity of the 183-DR head house in trenching operations conducted in January 2000 (Thornton et al. 2000b). This led to the discovery of an area of discolored soil at the northern end of the head house. Borehole C3040 was subsequently drilled at this location. The drilling of the two boreholes (C3040 and C3041) at 183-DR was initiated on July 20, 2000 (Table 1). Nearly continuous sediment core samples were collected from the boreholes for chemical and physical analysis from 20 feet to just below the water table at approximately 85 feet. The opportunity was taken during this work to complete one of the two boreholes, C3040, as a groundwater monitoring well, 199-D2-8.

Table 1. Drilling Summary

\begin{tabular}{||l|l|l|l|l|l|l|l||}
\hline \hline Well ID & Well Name & Start Date & $\begin{array}{c}\text { Finish } \\
\text { Date }\end{array}$ & $\begin{array}{c}\text { Northing } \\
(\mathrm{m})\end{array}$ & $\begin{array}{c}\text { Easting } \\
(\mathrm{m})\end{array}$ & $\begin{array}{c}\text { Ground } \\
\text { Surface } \\
\text { Elevation }(\mathrm{m})\end{array}$ & $\begin{array}{c}\text { Total } \\
\text { Depth (ft) }\end{array}$ \\
\hline \hline C3040 & $199-\mathrm{D} 2-8$ & $7 / 11 / 00$ & $8 / 7 / 00$ & 151208.864 & 573263.623 & 143.605 & 100.9 \\
\hline C3041 & Abandoned & $7 / 20 / 00$ & $8 / 1 / 00$ & 151191.699 & 573216.127 & 142.863 & 86.5 \\
\hline
\end{tabular}

The boreholes were drilled from the surface to 20 feet using an air rotary drilling method and from 20 feet to the final depth using the cable tool method. The top 20 feet at the site contains areas of concrete and debris from the demolition of the former 183-DR water treatment facility. Air rotary drilling was determined to be the most efficient method of drilling this zone, because the debris made drilling conditions relatively difficult. Samples were not obtained in the top 20 feet; however, this interval has been previously sampled by trenching (see Thornton et al. 2000b). Continuous split spoon cores of sediment were collected from a depth of 20 feet in the boreholes to just below the groundwater table. The primary goal for the boreholes was to sample the unsaturated zone for chromium concentrations, but they also provided the opportunity to obtain groundwater data in an area of high chromium concentrations. For this reason, each borehole was advanced to approximately 10 feet into the upper unconfined aquifer. A temporary well screen was then installed with a sand pack, and a groundwater sample collected. The temporary well completion consisted of installing a 2-inch diameter PVC wire-wrap screen with casing. The 5-foot screen was placed approximately 5 feet below the static water level, and the annulus outside the casing was backfilled with filterpack sand. The temporary well was then pumped with a Grundfos Redi-Flo-2 ${ }^{\mathrm{TM}}$ variable speed submersible pump until groundwater parameters stabilized. Groundwater samples were then collected (see Section 5.0).

Based on the analytical results for chromium, it was determined that borehole C3040 be deepened and completed as a RCRA groundwater well (199-D2-8) and C3041 be abandoned. Summary of the completion details are included in Appendixes A and B. Additional site-specific geologic descriptions are presented in Section 3.0. 


\subsection{Geophysical Logging Summary}

Geophysical logging was conducted through the casing in borehole C3041 on July 25, 2000. Total gamma-ray and neutron moisture logs are included in Appendix B.

A total gamma survey was performed using a $\mathrm{NaI}$ (sodium iodide) spectral logging tool, which helped identify stratigraphic changes in the borehole. An increase in total gamma activity was detected at a depth of about 47 feet, near the base of the Hanford formation. The gamma ray response was somewhat erratic from a depth of 47 feet to about 60 feet. This may be a reworked zone at the top of the Ringold Formation and was characterized as a silty sandy gravel during geologic logging (see Section 3.0). A more stable total gamma-ray baseline below 60 feet suggests that this is the top of undisturbed Ringold Formation sediments. The total gamma response was judged to be related to concentrations of natural radionuclides.

Neutron moisture logging was also performed in borehole C3041. The neutron count rate was relatively constant through the vadose zone, although values decreased in a zone between 40 and 50 feet depth. The water level in the casing was evident at a depth of 76 feet on the log. A static water level depth of 78.2 feet was recorded during drilling activities (Appendix B).

\subsection{Site Geology}

The stratigraphic units associated with the vadose zone and unconfined aquifer in the vicinity of the 183-DR site in descending order from the surface to depth are: localized Holocene surficial deposits and backfill, the informally defined Hanford formation, and the Rin gold Formation. Based on geological logging performed during the drilling of groundwater monitoring wells in the 100-D Area, the Hanford formation is generally present to a depth of about 55 feet; a coarse-grained unit of the Ringold is present from 55 to 98 feet; and a fine-grained unit of the Ringold Formation is present below 98 feet. Hanford formation sediment consists of 2 to 11 foot-thick interbedded sand and sandy gravel layers. Coarsegrained Ringold Formation Unit E deposits underlie the Hanford formation in the vicinity of 183-DR; these deposits consist of sandy gravels to sandy silty gravels. The Ringold Upper Mud Unit occurs locally at a depth of about 105 feet and acts as an aquitard that forms the base of the unconfined aquifer.

The specific geology at the 183-DR site is summarized in Figures 4 and 5 and detailed geologic log descriptions are presented in Appendixes A and B. The interval from the surface to 15 to 20 feet depth at the site is composed of backfill material containing broken concrete, piping, and reinforcing steel near the former location of the 183-DR facility with areas of relatively undisturbed sandy gravel, as determined by track hoe trenching activities. In some areas around the demolished facility, a 3 foot-thick reinforced concrete floor is still intact at a depth of approximately 23 feet. In areas away from the facility at depths between 16 to 20 feet, the sediments consist of large cobbles in a clast-supported matrix (i.e., lacking a finer grained matrix). Between 23 to 32 feet, the sediments are predominantly sandy gravel with a layer 


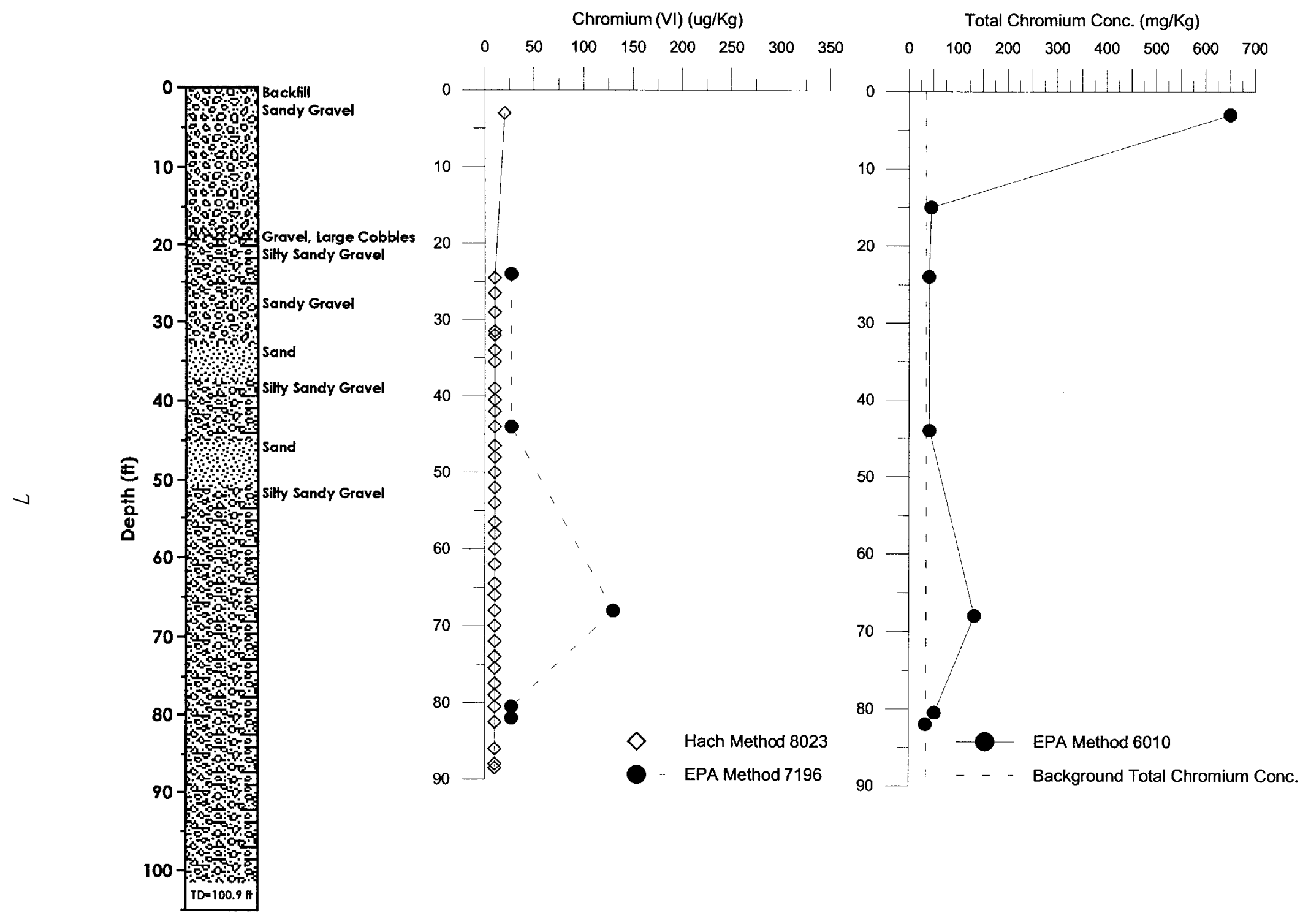

Figure 4. Generalized Geologic Logs and Cr Concentration versus Depth for Borehole C3040 and Trench 


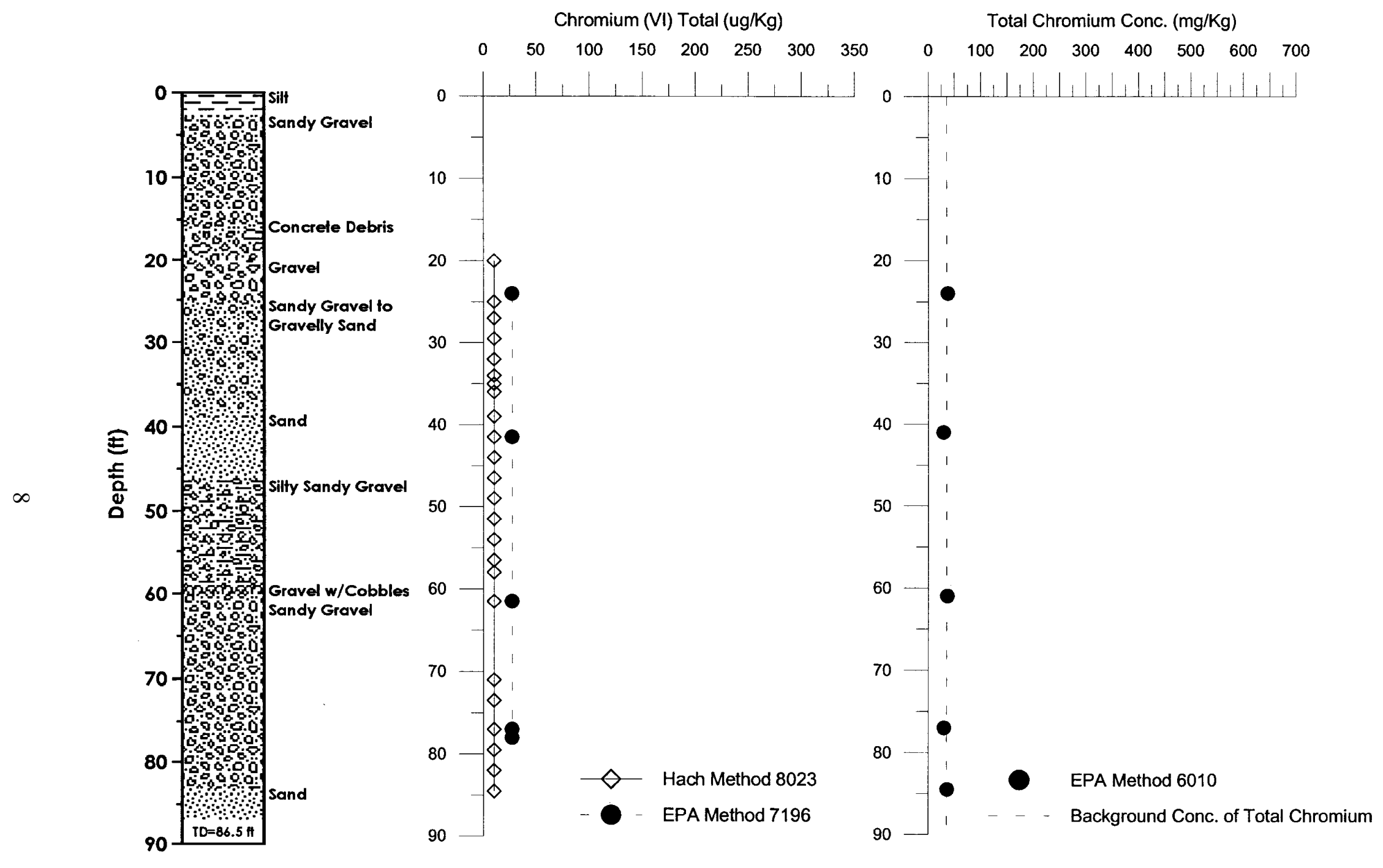

Figure 5. Generalized Geologic Logs and Cr Concentration versus Depth for Borehole C3041 
of sand between 32 to 36 feet. It is then silty sandy gravel to approximately 46 feet with a sand layer just above the contact with the Ringold Formation at 50 feet. The Ringold Formation was differentiated from the Hanford during logging by the higher percentages of silica-rich minerals. The sediment between 50 feet and the final depth of 100.9 feet in well C3040 was predominantly silty sandy gravel. The top of the unconfined aquifer was located at about 80 feet below ground surface within the Ringold Formation. The Upper Mud unit was not encountered in drilling borehole C3040 (well 199-D2-8) probably because drilling was terminated at 100.9 feet (see Figure 4), whereas the Upper Mud unit should occur near 105 feet.

\subsection{Vadose Zone Sediment Chemistry and Physical Properties}

Sediment samples collected at 183-DR during trenching and borehole drilling activities were analyzed for chemical constituents and underwent selecte d geotechnical tests, primarily measurement of moisture content and performance of grain size analyses. The chemical analytical data were utilized primarily to determine the distribution of hexavalent chromium at the site. Moisture content is useful from the standpoint of identifying zones that may contain higher levels of saturation. The grain size analyses are useful in providing estimates of permeability, which is an important consideration in the design of a potential future ISGR demonstration at the site.

\subsection{Sediment Analysis}

Analytical data for hexavalent chromium is available for vadose zone sediment samples collected using Geoprobe ${ }^{\mathrm{TM}}$ and cone penetrometer equipment at 183-DR from July through October 1999 (Thornton et al. 2000b). All data obtained indicated hexavalent chromium concentrations at or below $0.5 \mathrm{ppm}$. Additional sampling was undertaken in January 2000 during the excavation of the two trenches along the head house foundation (see Figure 3). A total of 50 samples (including duplicates) were analyzed for hexavalent chromium with generally no significant concentrations detected, though an area of discolored soil located at the northern end of the head house contained a trace of hexavalent chromium in one sample collected. Ten of the soil samples collected by excavation were analyzed for total metals by x-ray fluorescence (XRF). Most were uncontaminated with a total chromium concentration of 20 to 30 ppm (i.e., background). However, a discolored soil sample collected at the northern end of the head house at a depth of 3 feet contained about $650 \mathrm{ppm}$ total chromium, and was depleted in iron, manganese, and calcium and slightly enriched in lead. This area could have become contaminated as the result of drainage of water off the concrete slab associated with the chromate stock solution storage tanks. Another sample collected north of the head house at a depth of 15 feet had similar chemical characteristics and a total chromium content of $43 \mathrm{ppm}$, slightly above local background. This sample appeared to be associated with an area of alteration around a broken drain pipe.

The high level of total chromium content of the discolored soil thus suggests that chromium-bearing solutions may have entered the soil at the northern end of the head house, where chromate stock solution 
was stored in tanks, or by leakage of subsurface drainage pipes immediately to the north of the head house. Hexavalent chromium was apparently reduced to the trivalent oxidation state upon entering the soil and precipitated as $\mathrm{Cr}$ (III) oxyhydroxides (Rai et al. 1987) or other solid $\mathrm{Cr}$ (III)-bearing phases. This reaction could have been promoted by an acidic character of the solutions, which would have tended to accelerate reduction by ferrous-iron or organic matter in the soil and could also account for the slight orange-colored discoloration of the soil.

Borehole C3040 was drilled at the discolored soil location based on the evidence of release of chromium-bearing solutions from the head house. Continuous split spoon coring was conducted from a depth of 20 feet below the surface to 5 feet below the groundwater table in this borehole (see Figure 4 and Appendix A). Analysis of sediment samples from these cores was conducted for a variety of constituents as indicated in Appendix $\mathrm{C}$ for characterization and for waste designation purposes. In general, no significant indication of contamination was detected. However, a total chromium concentration of $132.8 \mathrm{ppm}$ and a hexavalent chromium concentration of $130 \mathrm{ppb}$ was reported for a sample collected in the depth interval of 68 to 68.5 feet in borehole C3040.

The second borehole, C3041, was located downgradient of C3040 because less than $2 \mathrm{ppm}$ hexavalent chromium was detected in a groundwater sample collected from C3040 (Section 5; Thornton et al. 2000a). Specifically, C3041 was positioned at a bend in the chemical transfer lines coming into the head house (Figure 3). Split spoon sampling was conducted in this borehole and the sediment samples analyzed (Appendixes B and C). No indication of contamination was identified in the sediment samples from C3041 and all total chromium concentrations were near background levels (Figure 5).

\subsection{Moisture Content Measurements}

The moisture contents of vadose zone sediment samples obtained from cores retrieved during drilling of boreholes C3040 and C3041 are presented in Table 2. Values ranged from 2.6 to $4.6 \mathrm{wt} \%$ and averaged $3.3 \mathrm{wt} \%$ for $\mathrm{C} 3040$ and $3.7 \mathrm{wt} \%$ for C3041. No discernable trend with depth is apparent, although the moisture content of samples collected in the interval of 41.5 through 47 feet were highest in both boreholes. This corresponds to an interval of sand located at a depth of about 40 to 50 feet and could reflect an increase in saturation near the contact of the Hanford and Ringold formations.

Table 2. Moisture Content of Sediment Samples Collected from Boreholes C3040 and C3041

\begin{tabular}{||c|c|c||}
\hline Borehole ID & Depth, ft & Moisture Content, wt\% \\
\hline \hline C3040 & 24.5 & 3.50 \\
\hline C3040 & $46.5-47$ & 4.40 \\
\hline C3040 & $68-68.5$ & 2.60 \\
\hline C3040 & $80.5-81$ & 2.60 \\
\hline C3041 & 25 & 3.40 \\
\hline C3041 & $41.5-42.5$ & 4.60 \\
\hline C3041 & $61.5-62.5$ & 3.10 \\
\hline C3041 & $77-78$ & 3.60 \\
\hline
\end{tabular}




\subsection{Grain Size Analyses and Estimation of Vadose Zone Permeability}

Three 5-gallon buckets of sandy gravel were collected at different locations during the trenching operations in intervals that were judged to be native undisturbed sediments. Grain size analysis by sieving (PNL 1993) was performed with this material, and the results were utilized to obtain estimates of permeability. This information is useful in ISGR design activities because vadose zone permeability determines gas flow rates.

Prior to the sieve analysis, the $>3 / 8$ inch fraction was removed from each sample and a portion of the $<3 / 8$ inch fraction submitted for analysis. The wt $\%$ greater than and less than $3 / 8$ inch is indicated in Table 3 for each sample. The results of the sieve analysis for the $<3 / 8$ inch fractions is presented in Table 4. Grain size distribution plots of the three samples are presented in Figure 6.

Table 3. Weight Percent of Size Fraction Greater and Less than 3/8 inch for Excavated Sediment Samples

\begin{tabular}{||c|c|c||}
\hline Sample ID & Wt\% > 3/8 Inch & Wt $\%<3 / 8$ Inch \\
\hline \hline N130 E130, depth $=15$ feet & 43.9 & 56.1 \\
\hline N131 E130, depth $=15$ feet & 62.3 & 37.7 \\
\hline N136 E130, depth $=25$ feet & 76.7 & 23.3 \\
\hline
\end{tabular}

Table 4. Sieve Analyses of Less than $3 / 8$ inch Fraction for Excavated Sediment Samples

\begin{tabular}{||c|c|c|c||}
\hline \hline Diameter $(\mu \mathrm{m})$ & $\begin{array}{c}\text { N130 E130 } \\
\%<\text { diameter }\end{array}$ & $\begin{array}{c}\text { N131E130 } \\
\%<\text { diameter }\end{array}$ & $\begin{array}{c}\text { N136E130 } \\
\%<\text { diameter }\end{array}$ \\
\hline \hline 4,000 & 79.46 & 84.66 & 73.68 \\
\hline 2,000 & 70.49 & 75.93 & 63.78 \\
\hline 1,000 & 61.56 & 64.87 & 52.09 \\
\hline 500 & 31.52 & 26.99 & 22.02 \\
\hline 250 & 12.46 & 4.62 & 3.27 \\
\hline 125 & 7.06 & 2.59 & 1.78 \\
\hline 63 & 3.46 & 1.41 & 1.13 \\
\hline 45 & 1.70 & 0.74 & 0.78 \\
\hline
\end{tabular}




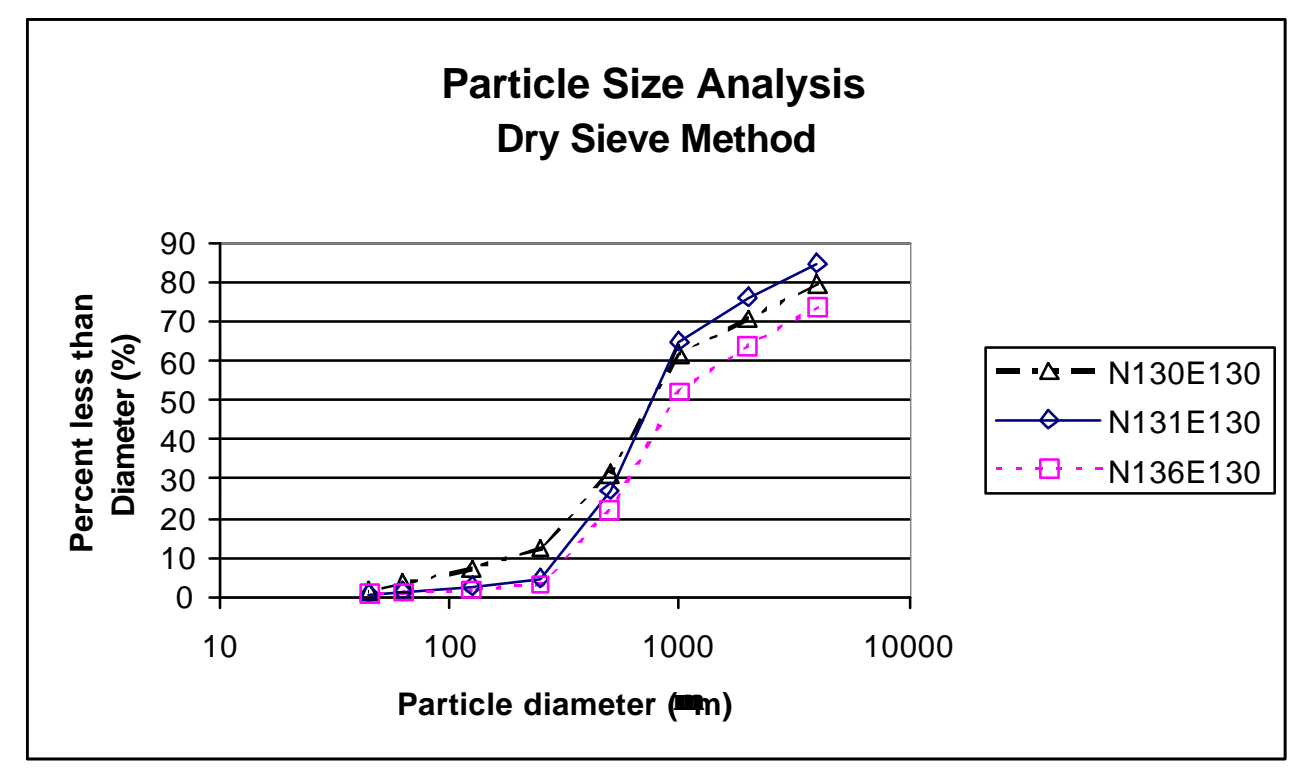

Figure 6. Grain Size Distributions of Less than 3/8 inch Fraction of Excavated Sediment Samples

Estimates of hydraulic conductivity of the samples were obtained from the grain size analyses using several theoretical models. An estimate of $700 \mathrm{~m} /$ day was obtained when the $>3 / 8$ inch fraction was included, and $200 \mathrm{~m} /$ day was obtained when only the $<3 / 8$ inch fraction was considered. This corresponds to intrinsic permeabilities of about $8.3 \times 10^{-10} \mathrm{~m}^{2}$ and $2.4 \times 10^{-10} \mathrm{~m}^{2}$, respectively, and provides a preliminary estimate of the range of permeabilities that could exist in the Hanford formation at the site. This information has been utilized to support initial modeling activities in support of a possible ISGR demonstration at 183-DR. Numerical simulations with the Subsurface Transport Over Multiple Phases (STOMP) simulator (White and Oostrom 1996) suggest that a high flow rate should be achievable (200 cfm at 2 psig pressure) owing to the high permeability of the vadose zone at the site. Good gas capture characteristics have been indicated with respect to STOMP pressure field and tracer simulations for an extraction to injection flow rate ratio $\left(\mathrm{Q}_{\text {out }} / \mathrm{Q}_{\text {in }}\right)$ of 1.1 or greater.

\subsection{Groundwater Chemistry and Well Development}

Groundwater samples were collected from boreholes C3040 and C3041 for chemical analysis. Borehole C3041 was abandoned, but borehole C3040 was completed as a monitoring well. Presented below are aspects of the groundwater chemistry, especially chromium concentration levels, and information associated with development of the temporary and permanent well completions. 


\subsection{Groundwater Chemistry Summary}

Groundwater samples were collected from temporary completions in boreholes C3040 and C3041 and analyzed for cations and anions and organic and radionuclide constituents. The results of these analyses are presented in Appendix C. The only contaminant noted was hexavalent chromium, which was reported at a concentration of $1,490 \mu \mathrm{g} / \mathrm{L}(\mathrm{ppb})$ in the sample collected from C3040 and $87 \mu \mathrm{g} / \mathrm{L}$ in the sample from C3041. Total chromium concentrations of $1,600 \mu \mathrm{g} / \mathrm{L}$ and $93.7 \mu \mathrm{g} / \mathrm{L}$ were reported for the C3040 and C3041 samples, respectively. Hexavalent chromium concentrations in the 100-D Area are commonly similar to total chromium concentrations, indicating that most of the dissolved chromium is in the hexavalent oxidation state as the chromate anion, $\mathrm{CrO}_{4}{ }^{2-}$.

The groundwater data for total chromium concentrations at 183-DR and other groundwater monitoring wells in the 100-D Area are presented in Figure 7, which illustrates the configuration of two major chromium plumes in mid-calendar year 2000. The configuration of the plume in the vicinity of 183-DR is generally similar to earlier interpretations (Rohay et al. 1999 and Thornton et al. 2000a). However, this more recent data plus the information from C3040 and C3041 indicates that the center of the plume is displaced slightly to the north relative to earlier work. This suggests that the vadose zone source of hexavalent chromium at 183-DR could be associated with the chromate chemical transfer lines to the west of the head house or a drainline located north of the head house. Analyses of soil samples collected at the 100-D Sodium Dichromate Transfer Station (Figure 7) suggest that significant concentrations of hexavalent chromium are not present at that location (Thornton et al. 2000b).

Hexavalent chromium concentrations in the 100-D Area groundwater plumes approach maximum values of about $2 \mathrm{mg} / \mathrm{L}$ (ppm) as indicated in Figure 7. This observation suggests that the aquifer may be saturated with respect to a chromate mineral phase that has previously precipitated and is now redissolving (i.e., hexavalent chromium concentrations may be solubility controlled). To assess this possibility, the analytical data presented for the C3040 groundwater sample was utilized to determine solution speciation and to calculate the saturation indices for various mineral phases. The MINTEQA2 geochemical equilibrium speciation model developed by EPA was employed for this purpose (Allison et al. 1991). In these calculations, alkalinity of the sample was calculated to be approximately $100 \mathrm{mg} / \mathrm{L} \mathrm{CaCO}_{3}$ based on charge balance considerations. Results obtained by the model indicated the sample was highly undersaturated with respect to nine different chromate minerals. The solid phase closest to saturation was $\mathrm{BaCrO}_{4}$ (saturation index $=\log \mathrm{Q} / \mathrm{K}=-1.529$ ). Thus, no common chromate mineral phase has yet been recognized that could provide a solubility control for hexavalent chromium concentration levels present in the aquifer. Solid solution of chromate in mineral phases such as calcite or gypsum could provide a solubility control but it is not possible at present to assess this potential mechanism.

\subsection{Well Development Activities}

There were two stages of well development at 183-DR. The first stage was to develop the well using a temporary well screen after the borehole was advanced 10 feet into the unconfined aquifer; this activity was undertaken for both boreholes. The second stage, installation of a permanent monitoring well, was conducted only in borehole C3040 after the well was completed at a depth of 20 feet into the unconfined aquifer. 


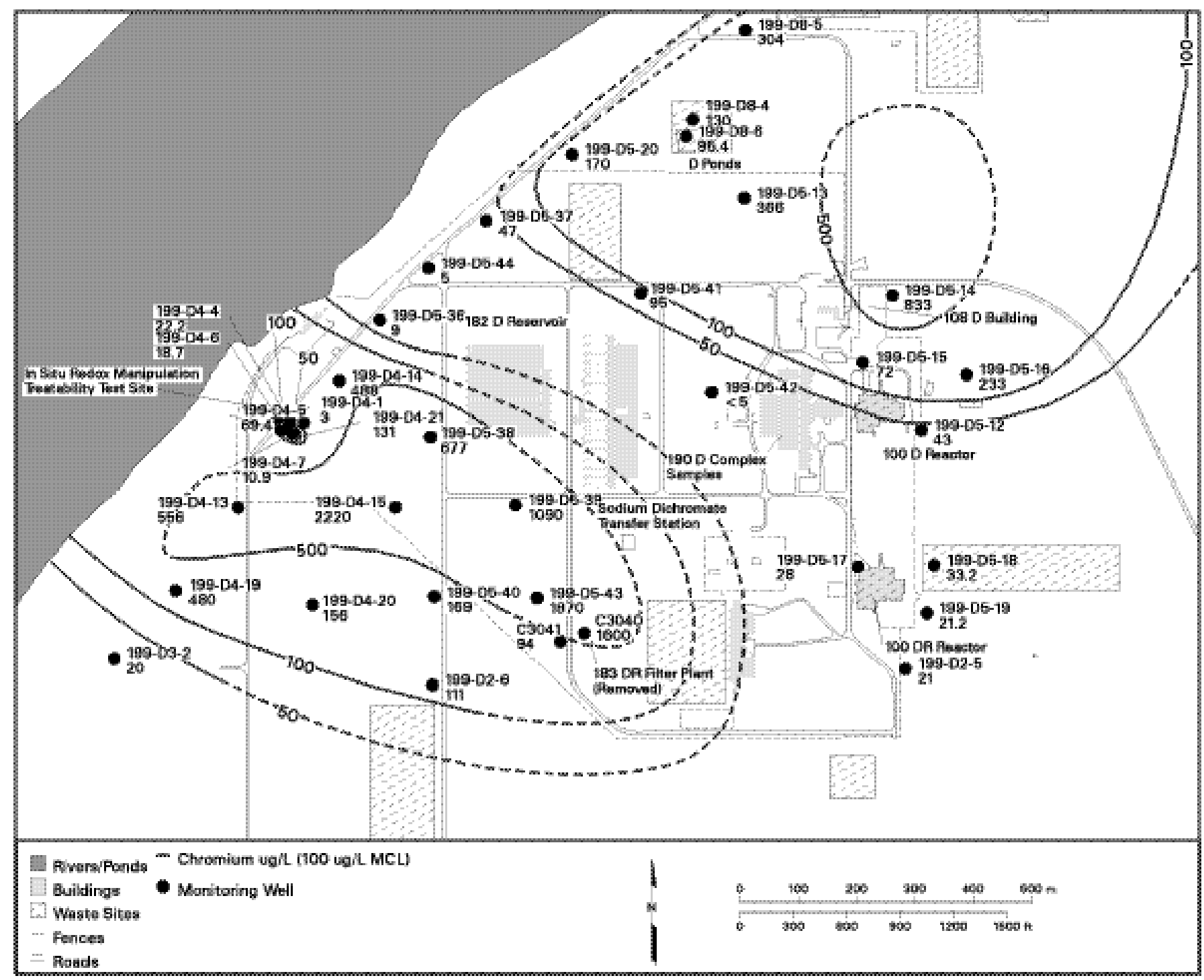

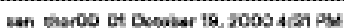

Figure 7. Facilities and Cr(total) Groundwater Plumes in the 100-D Area in mid-Calendar Year 2000 
The first stage of development was conducted after a temporary PVC well casing and screen were placed in the borehole and then backfilled with filterpack sand after the borehole was advanced 10 feet into the aquifer. The temporary steel casing was then pulled back above the water table to expose the PVC well screen. Each well was pumped using an electric submersible pump until the groundwater parameters specific conductance, $\mathrm{pH}$, and hexavalent chromium concentrations stabilized, and turbidity decreased to below 5 NTU. Additional groundwater samples were collected for chemical and radiological analysis after the groundwater parameters stabilized (Appendix C). The results for hexavalent chromium as determined in the field using Hach Method 8023, which is equivalent to EPA Method 7196 (EPA 1992), are shown in Figure 8. A total of 900 gallons of water were pumped in 180 minutes from borehole C3040 during development and a total of 583 gallons were pumped in 180 minutes from borehole C3041. The drawdown in C3041 was 1.2 feet after 180 minutes while pumping at 3.3 gallons per minute. Although an accurate drawdown was not measured in C3040, it can be qualitatively stated that the drawdown was less in C3040 in comparison to C3041 even while pumping at a higher discharge rate of $5 \mathrm{gpm}$. This indicated borehole C3040 was a better water producer.

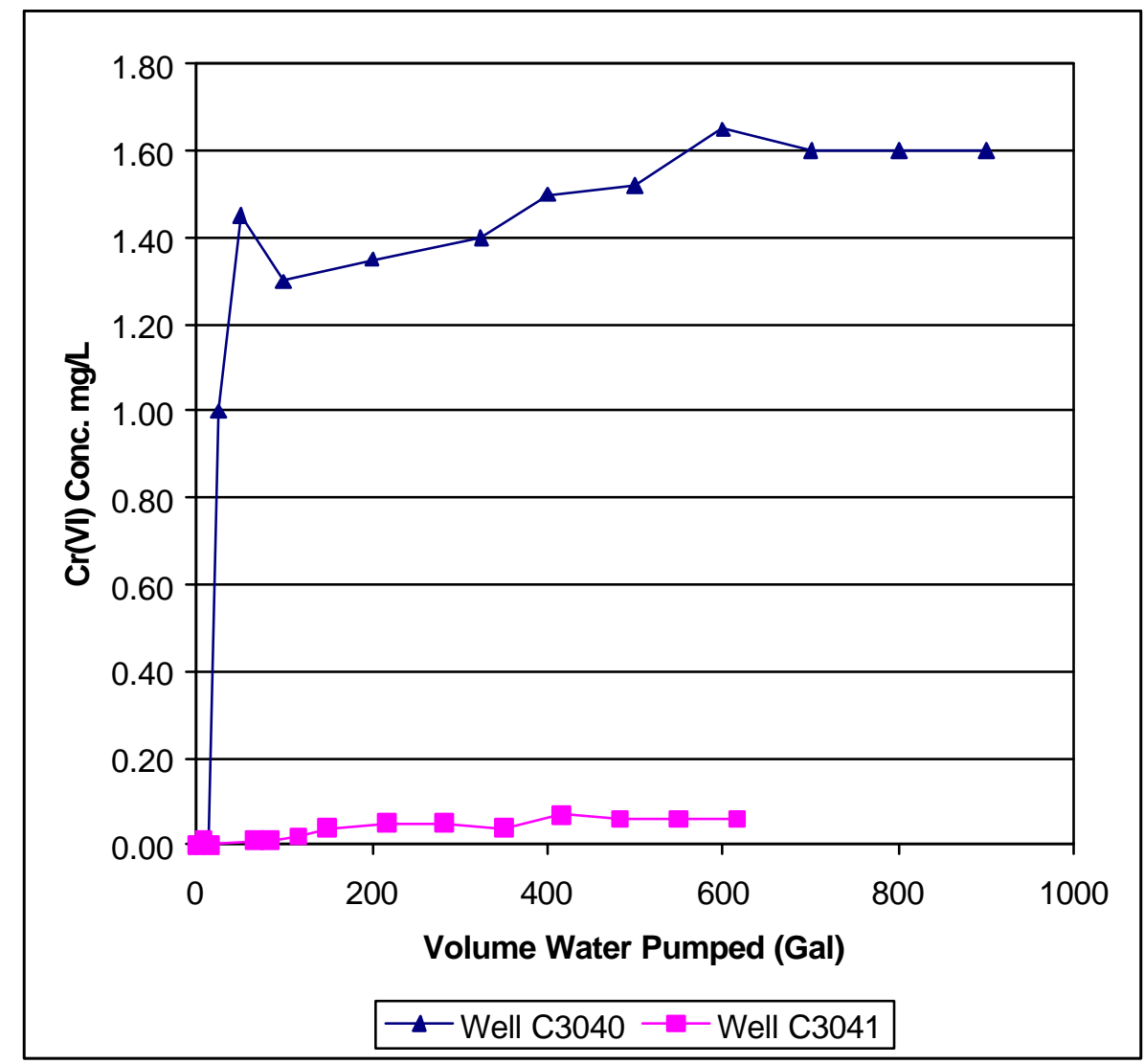

Figure 8. Cr(VI) Concentration in Development Water from Boreholes C3040 and C3041 
Owing to its higher potential flow rates, borehole C3040 was completed as a permanent groundwater monitoring well. The hole was deepened to 100.9 feet to accommodate a 20 -foot well screen. The well was again developed after the final completion with stainless steel well casing and screen. During this second stage of development, sand was placed around the screen, and the well was initially developed using a bailer to settle the sandpack. After the annulus was backfilled with bentonite and grout to the surface, the well was developed using an electric submersible pump. A total of 1,882 gallons of water were pumped in 174 minutes. The total drawdown after 174 minutes of pumping at $10.8 \mathrm{gpm}$ was 12 feet. The development proceeded in steps where the flow rate was slowly increased to 10.8 gallons. At this flow rate the water level was approximately 1 foot above the pump intake. The pumping continued until the groundwater temperature, $\mathrm{pH}$, specific conductance, and the concentration of hexavalent chromium stabilized and the turbidity decreased to below 5 NTU. The well fully recovered to static water level approximately 30 minutes after the pump was turned off.

\subsection{Laboratory Treatment Tests}

A number of laboratory treatment tests have been conducted to date that indicate diluted hydrogen sulfide is very efficient in reducing hexavalent chromium in soil. However, it is important to conduct site-specific treatment tests for each location where ISGR may be applied. The objectives of these sitespecific treatment tests are to verify that an acceptable level of reduction can be achieved and to obtain an estimate of treatment gas consumption that is expected as hydrogen sulfide interacts with site sediment. These tests typically involve packing contaminated soil into columns and passing a diluted hydrogen sulfide gas mixture through the column at a known flow rate and concentration. Treatment progress can be monitored by recording the concentration of hydrogen sulfide at the column exit (i.e., the degree of breakthrough achieved). After treatment is complete, leaching of the column is undertaken and the mass of hexavalent chromium recovered is determined by analysis of leachate samples. An untreated soil column is also leached to determine the total mass of hexavalent chromium originally present. Comparison of the mass of hexavalent chromium recovered from the two columns provides a basis for determination of the degree of immobilization achieved during the gas treatment test.

Early experimental activities conducted during the development of the ISGR approach included treatment of sediments from the Hanford formation that were spiked with hexavalent chromium at the 200 ppm level (Thornton and Jackson 1994). Treatment with 2,000 and 100 ppm hydrogen sulfide treatment gas mixtures were undertaken and the treated soil columns leached with groundwater. Leachate analyses indicated that $94.6 \%$ and $98.4 \%$ immobilization of chromium was achieved, respectively. More recently, a sample of soil from the 183-KW site at Hanford has been tested that contains about 203 ppm hexavalent chromium, as determined by leaching of an untreated soil column. Leaching of the soil after treatment with a $200 \mathrm{ppm}$ hydrogen sulfide mixture indicated essentially $100 \%$ reduction of hexavalent chromium in the soil. The higher degree of immobilization observed in this test compared to earlier tests can be attributed to a longer period of treatment. These results thus indicate that a minimum of $95 \%$ immobilization should be achievable by gas treatment at 183-DR under ideal conditions. Treatment operations may be less effective in the field in many cases, depending on gas flow characteristics and the 
extent of stratigraphic heterogeneity. As indicated in Section 4.3, however, the high permeability of this site makes it an ideal candidate for the ISGR approach.

Drilling activities at several Hanford Site locations have indicated that generation of hydrogen gas can occur (e.g., Bjornstad et al. 1994). This appears to result from the reduction of water. This may be attributed to the breakage of basalt cobbles, with resulting exposure of ferrous-iron bearing surfaces, or by introduction of metal shavings from a drill bit or drive casing. It has been suggested that hexavalent chromium in the vadose zone at Hanford may be reduced during drilling as the result of hydrogen generation or by direct reduction by basalt or shavings. The split spoon sediment sampling undertaken in the vadose zone at 183-DR was conducted ahead of the cable tool drive casing, however, and thus reduction of hexavalent chromium by broken rock or metal shavings would not be expected. However, the potential for the diffusion of hydrogen ahead of the drive casing should be considered as a possible mechanism for reduction of hexavalent chromium. To test this hypothesis, two more columns were packed with the $\mathrm{Cr}(\mathrm{VI})$-contaminated soil collected at the $183-\mathrm{KW}$ site. One of these columns was treated with a mixture of $4 \% \mathrm{H}_{2}$ in $\mathrm{N}_{2}$ at a flow rate of $100 \mathrm{cc} / \mathrm{min}$ for more than 29 hours. The treated and untreated columns were then leached with deionized water and the leachate samples analyzed for hexavalent chromium. No significant difference in hexavalent chromium concentrations were observed between the two sets of leachate samples, indicating that $\mathrm{H}_{2}$ did not reduce any of the chromate present in the treated column. Thus, it is concluded that hydrogen generation by drilling is probably not an important process for reducing hexavalent chromium in the vadose zone. It is concluded that the cored sediments recovered at 183-DR were probably not significantly altered by drilling activities.

Gas treatment tests have also been completed on the $<3 / 8$ inch fraction of soil collected during the trench excavations (Section 4.3). The purpose of these tests was to determine the extent of treatment gas consumption by the soil matrix and to obtain information regarding the specific reactions between $\mathrm{H}_{2} \mathrm{~S} / \mathrm{N}_{2}$ and $\mathrm{H}_{2} \mathrm{~S} /$ air gas mixtures and soil components. Mixtures of $200 \mathrm{ppm}$ hydrogen sulfide in nitrogen and in air were employed in two column treatment tests. Both tests were run until a high degree of breakthrough was achieved $\left(C / \mathrm{C}_{\mathrm{o}}>0.8\right)$. The consumption ratio of hydrogen sulfide to soil by mass was determined to be $1.0 \times 10^{-3}$ for the $\mathrm{H}_{2} \mathrm{~S} / \mathrm{N}_{2}$ test and $0.3 \times 10^{-3}$ for the $\mathrm{H}_{2} \mathrm{~S} /$ air test. However, as indicated above, the $>3 / 8$ inch fraction of the soil was removed before packing into the columns. This gravel-sized material would likely consume less hydrogen sulfide on a mass basis owing to the lower specific surface area. A breakthrough of less than $80 \%$ should also be adequate for reduction of hexavalent chromium by hydrogen sulfide at the site, since the rate of this reaction appears to be fast (i.e., most of the treatment gas is consumed by slower reactions of hydrogen sulfide with soil iron oxides). Thus, a consumption ratio of about $1 \times 10^{-4}$ should be adequate for the application of ISGR at 183-DR.

The time required to achieve treatment during an ISGR demonstration at 183-DR can be estimated on the basis of the mass associated with the treatment zone, the mass of hydrogen sulfide required per unit mass of soil, and the concentration and flow rate of treatment gas through the site flow cell. Assuming the zone targeted for treatment is 15 feet thick and 60 feet in diameter, the volume of soil involved is 42,412 cubic feet. Based on a bulk density of about $100 \mathrm{lb} / \mathrm{ft}^{3}$ measured in laboratory column tests, approximately $4.24 \times 10^{6}$ pounds of soil is located in the treatment interval. As indicated above, a gas consumption ratio of $1 \times 10^{-4}$ should be adequate to treat hexavalent chromium within the flow cell. Thus, approximately 424 pounds of hydrogen sulfide will be needed to treat the zone. If the treatment gas 
is injected into the site as a $200 \mathrm{ppm}$ hydrogen sulfide mixture at a flow rate of $200 \mathrm{cfm}$, the time required to achieve a moderate level of breakthrough is expected to be roughly 78 days. However, because the treatment time required is inversely proportional to gas concentration and flow rate, the time associated with amount of time needed for treatment could be reduced by increasing the hydrogen sulfide concentration of the injection gas stream or by injecting at a higher flow rate.

\subsection{Conclusions and Recommendations}

Characterization activities conducted at 183-DR in the course of this study did not locate the vadose zone source of hexavalent chromium that has contaminated the underlying aquifer. Thus, it is not possible to proceed with an ISGR demonstration at 183-DR at this time. However, the groundwater data collected from boreholes C3040 and C3041, combined with that available from other monitoring wells in the area, has provided a better understanding of the geometry of the groundwater plume. The chromate chemical transfer lines located to the west of the 183-DR head house or a drainline north of the head house could be areas for future site investigations and a potential ISGR deployment.

Additional upgradient groundwater monitoring wells could help to identify the vadose zone source of hexavalent chromium at 183-DR. In particular, completion of a monitoring well near the former 183-DR filter plant would be useful in helping to establish the upgradient configuration of the plume. It is recommended that split spoon sampling of vadose zone sediments be undertaken as described in this study during installation of wells and sediments be analyzed for hexavalent and total chromium in the event that the source is encountered during drilling.

One or more vadose zone sources of hexavalent chromium may be discovered in the future at 183-DR. If a region of hexavalent chromium is identified, excavation can be undertaken to define the source and potentially remove it. Application of ISGR can then be considered for remediation of hexavalent chromium contamination if it is present above action levels at significant depths in the vadose zone.

\subsection{References}

Allison, J.D., D.S. Brown, and K.J. Novo-Gradac. 1991. MINTEQA2/PRODEFA2, A Geochemical Assessment Model for Environmental Systems: Version 3.0 User's Manual. EPA/600/3-91/021. Environmental Research Laboratory, U.S. Environmental Protection Agency, Athens, Georgia.

Bjornstad, B.N., J.P. McKinley, T.O. Stevens, S.A. Rawson, J.K. Fredrickson, and P.E. Long. 1994. "Generation of Hydrogen Gas as a Result of Drilling within the Saturated Zone." Ground Water Monitoring and Remediation, p. 140-147. 
Pacific Northwest Laboratory (PNL). 1993. Procedures for Groundwater Investigations. PNL-MA-567, Rev. 1, Pacific Northwest Laboratory, Richland, Washington.

Rai, D., B.M. Sass, and D.A. Moore. 1987. "Chromium Hydrolysis Constants and Stability of Chromium(III) Hydroxide.” Inorganic Chemistry, v.26, p. 345-349.

Richards, R.B. 1953. Process Specifications Reactor Cooling Water Treatment. HW-28505, General Electric, Richland, Washington.

Rohay, V.J., D.C. Weekes, W.J. McMahon, and J.V. Borghese. 1999. The Chromium Groundwater Plume West of the 100-D/DR Reactors: Summary and Fiscal Year 1999 Update. BHI-01309 Rev. 0, Bechtel Hanford, Inc., Richland, Washington.

Thornton, E.C. and R.L. Jackson. 1994. Laboratory and Field Evaluation of the Gas Treatment Approach for In Situ Remediation of Chromate-Contaminated Soils. Proceedings of the 33rd Hanford Symposium on Health and the Environment, Pasco, Washington, p. 949-963.

Thornton, E.C., J.T. Giblin, T.J Gilmore, K.B. Olsen, J.M. Phelan, and R.D. Miller. 1999. In Situ Gaseous Reduction Pilot Demonstration - Final Report. PNNL-12121, Pacific Northwest National Laboratory, Richland, Washington.

Thornton, E.C., K.B. Olsen, and R. Schalla. 2000a. Description of Work for Drilling at the 183-DR Site in Support of the In Situ Gaseous Reduction Test. PNNL-13261, Pacific Northwest National Laboratory, Richland, Washington.

Thornton, E.C., K.J. Cantrell, J.M. Faurote, T.J Gilmore, K.B. Olsen, and R. Schalla. 2000b. Identification of a Hanford Waste Site for Initial Deployment of the In Situ Gaseous Reduction Approach. PNNL-13107, Pacific Northwest National Laboratory, Richland, Washington.

U.S. Environmental Protection Agency (EPA). 1992. Test Methods for Evaluating Solid Waste Physical/Chemical Methods, $3^{\text {rd }}$ ed. SW-846. U.S. Environmental Protection Agency, Washington, D.C.

White, M.D., and M. Oostrom. 1996. STOMP Subsurface Transport Over Multiple Phases, Theory Guide. PNNL-11217, Pacific Northwest National Laboratory, Richland, Washington.

Westinghouse Hanford Company (WHC). 1993. 100-D Area Technical Baseline Report. WHC-SD-ENTI-181, Rev. 0, Westinghouse Hanford Company, Richland, Washington. 


\section{Appendix A}

Well Construction Summary Report and Borehole Log for Borehole C3040 


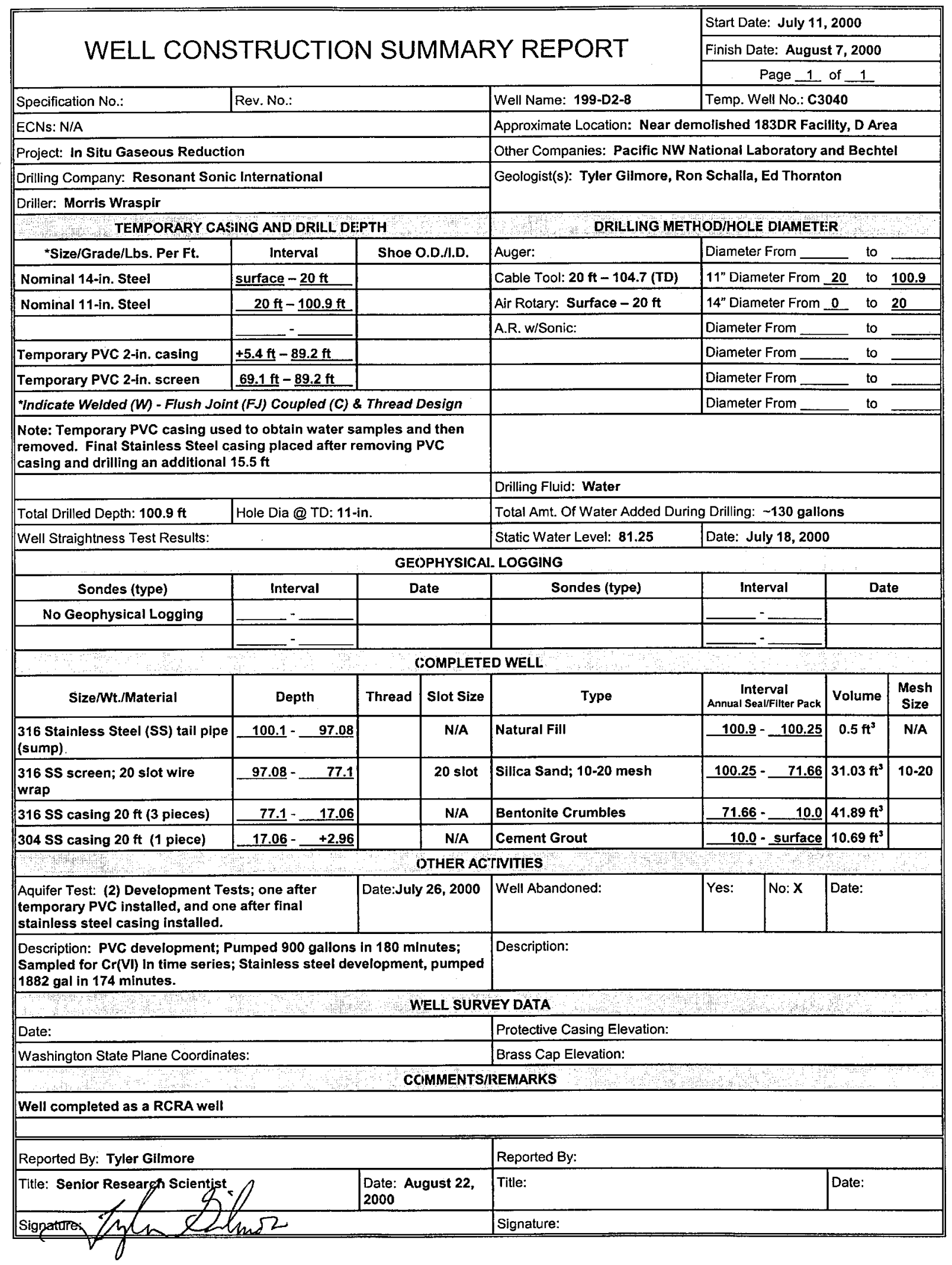




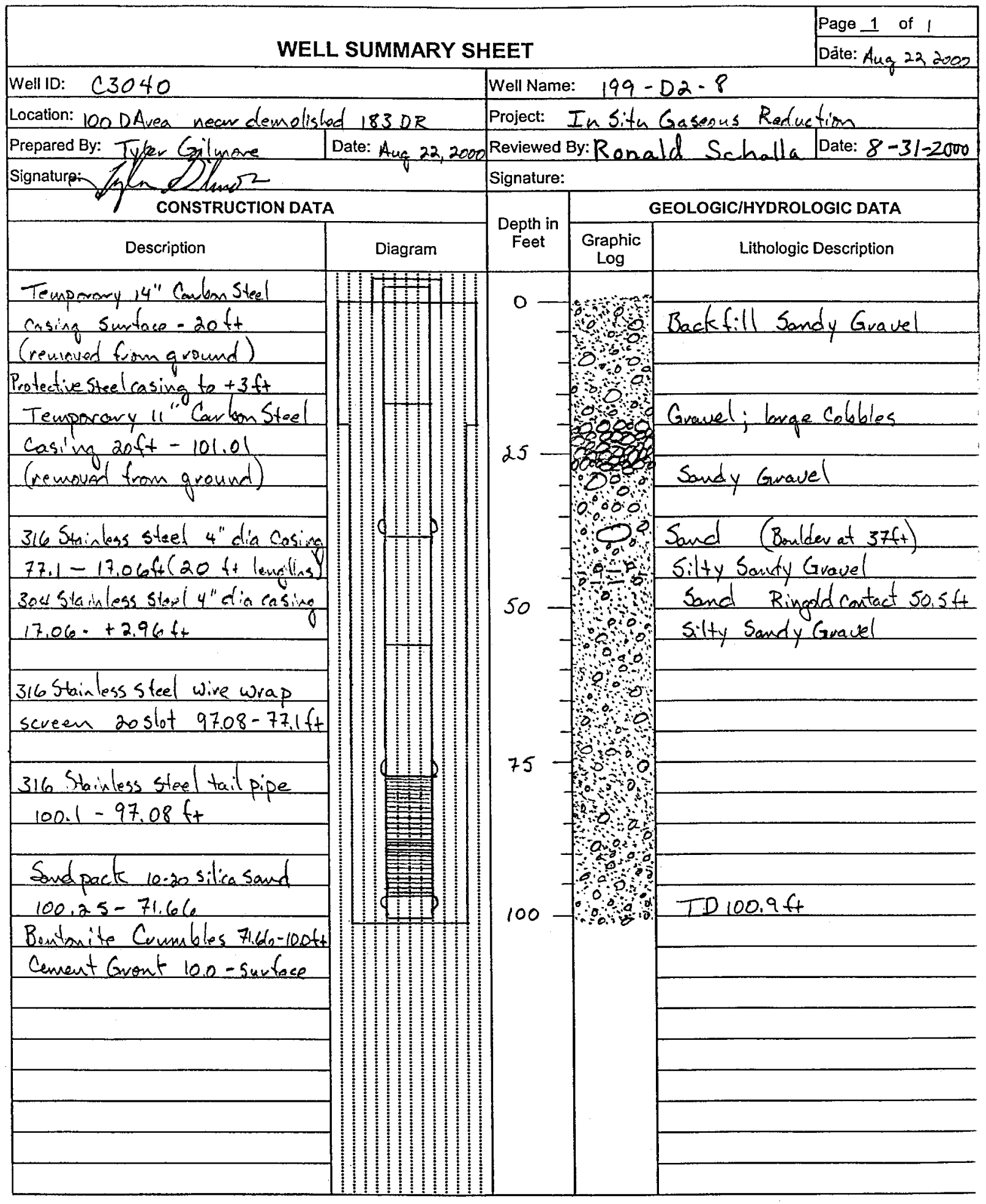




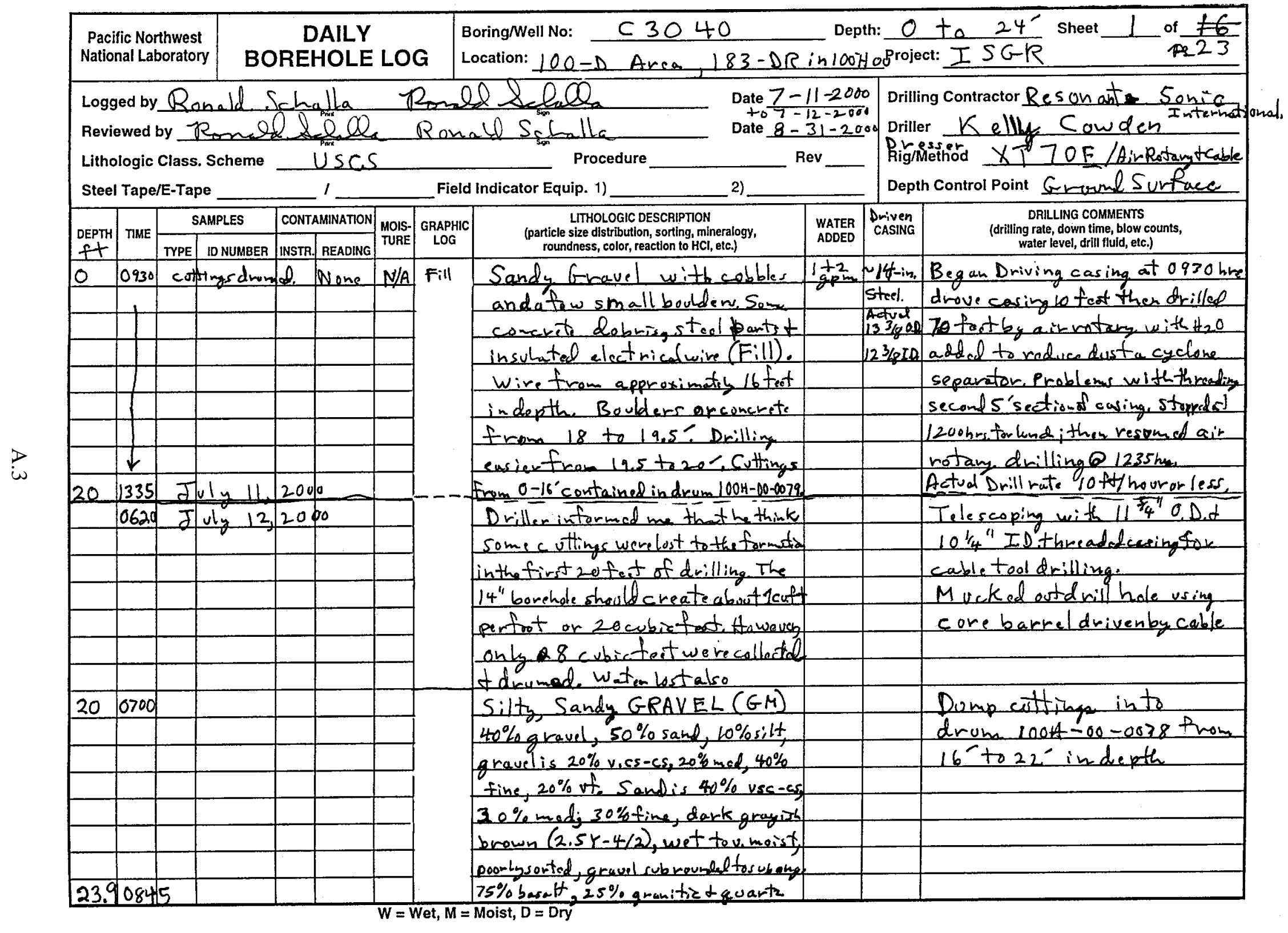




\begin{tabular}{|c|c|c|c|c|c|c|c|c|c|c|c|}
\hline \multicolumn{3}{|c|}{$\begin{array}{l}\text { Pacific Northwest } \\
\text { National Laboratory }\end{array}$} & \multicolumn{4}{|c|}{$\begin{array}{l}\text { DAILY } \\
\text { BOREHOLE LOG }\end{array}$} & & \multicolumn{4}{|c|}{ 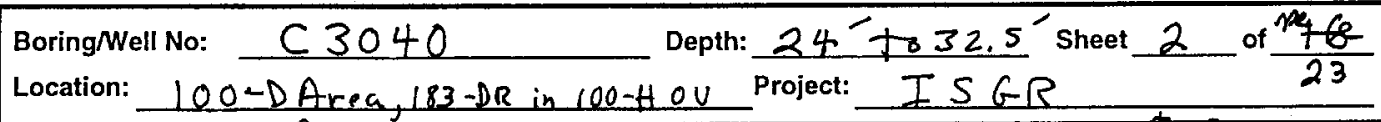 } \\
\hline \multicolumn{6}{|c|}{ 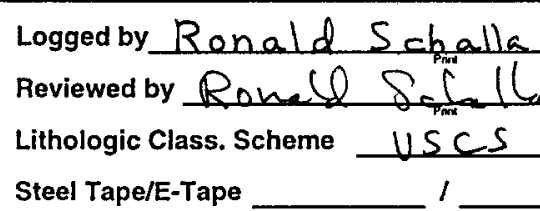 } & 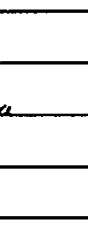 & - Field & \multicolumn{2}{|c|}{ Ponel \&ed Date $7-12-2000$} & \multicolumn{2}{|c|}{ 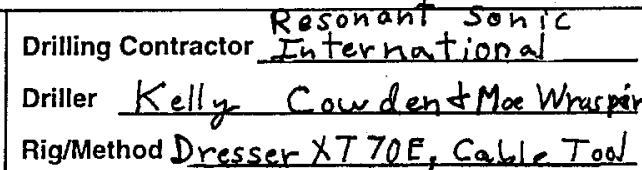 } \\
\hline $\begin{array}{l}\text { DEPTH } \\
\text { ft }\end{array}$ & TME & TYPE & ID NUMBER & CONTA & AMINATION & MOIS- 0 & $\begin{array}{l}\text { GRAPHIC } \\
\text { LOG }\end{array}$ & 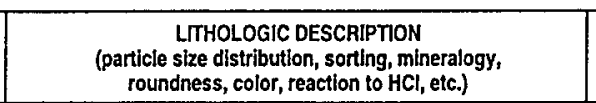 & $\begin{array}{l}\text { WATER } \\
\text { ADDED }\end{array}$ & $\begin{array}{l}\text { Drivan } \\
\text { CASING }\end{array}$ & $\begin{array}{l}\text { DRILLLNG CoMMENTS } \\
\text { (drilling rate, down time, blow counts, } \\
\text { water level, drill fluld, etc.) }\end{array}$ \\
\hline 2400 & 9900 & 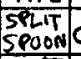 & C3040-24.5 & GM & Buckgral & dry: & (5:00: & Sandy GRAVEL (GW) with $5 \%$ & None & $11,750,0$ & Drove sampler from $24+t o$ \\
\hline 24.5 & & $\begin{array}{ll}\text { Most } \\
\text { VoA }\end{array}$ & C3040.245 & GM & in & & ( & orless sitt. $50 \%$ gravil $45 \%$ & & $10,25 I .0$ & $26.5 \mathrm{ft}, \%$ recolvery was $40 \%$ \\
\hline $\begin{array}{l}24.5-5 \\
25.0 \\
\end{array}$ & & $\operatorname{lin}^{6 \prime \prime} \mid \mathrm{s}$ & c3040-2958 & $6 M$ & $n$ & & $\begin{array}{ll}0 \\
0\end{array} \therefore 0$ & sand and $5 \%$ sitt, Gravel is & & & Casing a duancol attersamply \\
\hline $25+0$ & & No & Recover & & & & 8000 & similar in partide size as & & & I borehole cleamal aut to 26.5 \\
\hline 26,5 & & & L & & & & $\begin{array}{ll}0.00 \\
0.00 \\
0.00\end{array}$ & above dark groy $(10 Y R-4 / 1)$ & & & All drilling by corebarial \\
\hline 26.520 & & splitich & C3040-26.5 & GM & ackgan & $d r y$ & $\therefore 0=0$ & dry to slightly maist & & & cabletorle? \\
\hline 27.03 & & Lomant & $=3040-27$ & $u$ & .0 & & & (a) 26.5 sinilat to a bove & & & Nent sample. $26.5^{\prime}$ to $29.0^{\prime}$ \\
\hline 27.55 & & Linets & $63040-22.5$ & 1, & 3 & & 800 & but some what coarser and & & & ouly recovicy 1.5 of sample \\
\hline 28.08 & & & & & & & ( & Slightly more maist, & & & or $60 \%$ L arge colbeb \\
\hline 28 & & Nof & & & & & ( ) & & & & probablablockolene. \\
\hline 24 & & & & & & & $\begin{array}{l}0.00 \\
0.00 \\
0.00\end{array}$ & & & & \\
\hline $29-$ & & Solits & $c 3040-29$ & $G M$ & Buctugn & & 0 & Silty Sand GRAugL (GM) & & & Sampled at $29.0+0.31 .5^{\prime}$ \\
\hline 29,53 & & Spronge & $c 3040-294$ & $\because$ & .0 & & 0 & $40 \%$ gravel, $40 \%$ sand, $20 \%$ silt & & & Onlykecourrd 1.5'oframple \\
\hline 30.08 & & Liveres & $=3040-30$ & 4 & $\because$ & & ( & silt decreasing to $10^{\circ} \mathrm{L}_{\mathrm{b}}$ & & & or $60 \%$ recovery, Somesant \\
\hline 30.5 & & & & & & & 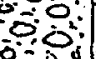 & $30.5 \mathrm{ft}$ gravelis $10 \%$ r.csc,cs. & & & follout af bottom of the 4 " \\
\hline $30.5-$ & & No & Recoveny & & & & 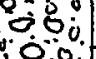 & $30 \%$ med, $40 \%$ atine, $20 \%$ of & & & Lexan linen at the bottin. \\
\hline 315 & & & & & & & 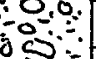 & Sand is genowally fincr then & & & \\
\hline 31.5 & & Lexun & c3040-31.5 & $G M$ & Backgnt & and $10^{\circ}$ & 00 & above samplos. Lavge increase & & & Sampled from 31.5 to 344 \\
\hline 32,0 & & Lines & $03040-34$ & 11 & 4 & & $=\because 0$. & in silt content from 29.5 to & & & recoveral $1.8 \mathrm{ft}$ or $70 \%$. \\
\hline 32.53 & & & $c 3040-325$ & 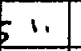 & $\because$ & & 0.0 & $30.5 f_{e a}+D_{r y}$ gray $(10 Y R-5 / 1)$ & & & \\
\hline 33,01 & & & & & & & 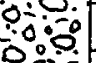 & $70 \%$ bas alt, $30 \%$ otherincluding & & & \\
\hline $33+6$ & & Not & Recovey & & & & 0.0 .0 & about $10 \%$ guartz, chert,etc. & & & \\
\hline 34 & & & & & & & ( & same to $32.5 \mathrm{ft}$. & & & \\
\hline & & & & & & & $0.0: 0$ & $32,5^{\prime}$ & $\checkmark$ & & \\
\hline
\end{tabular}




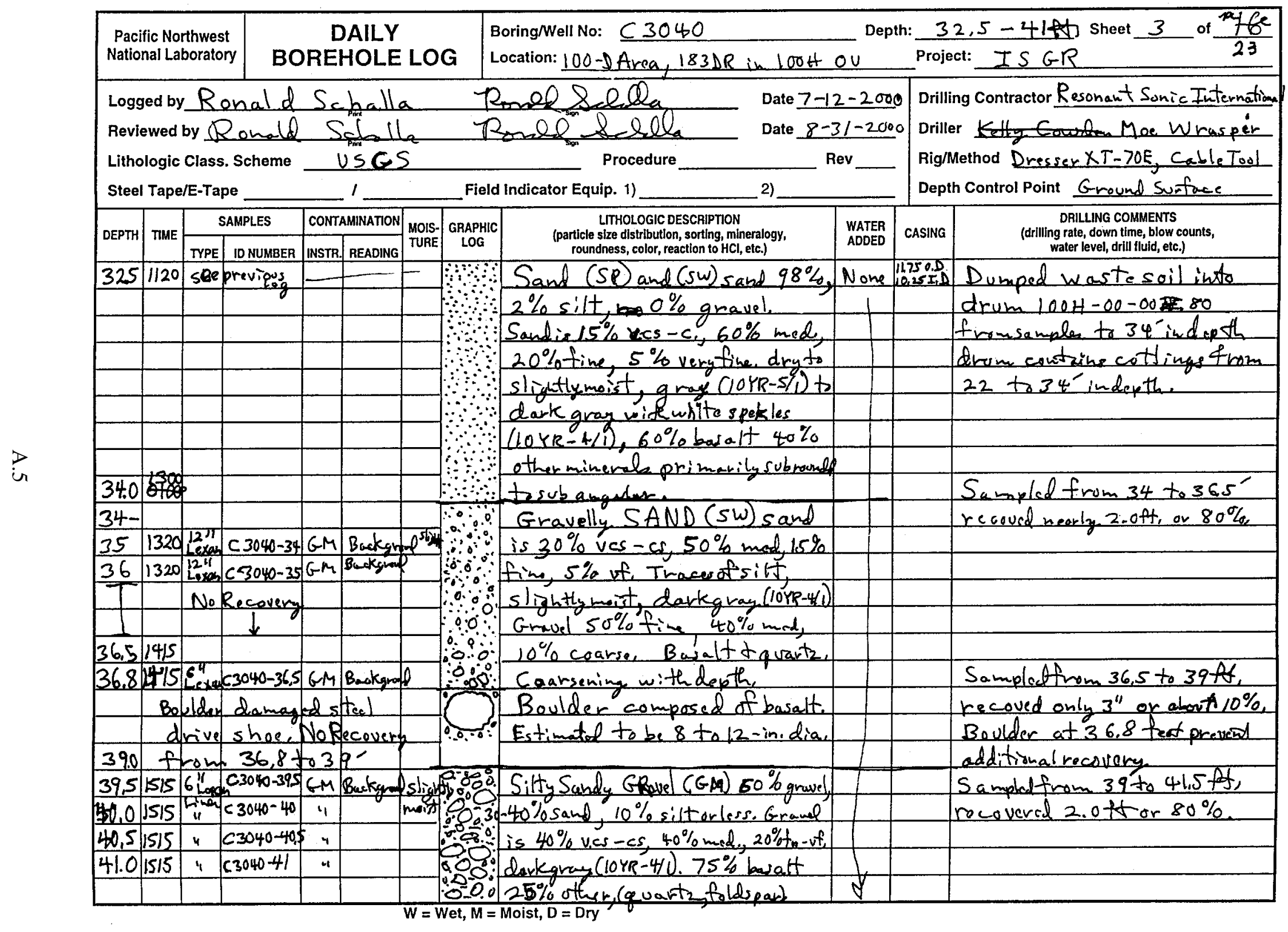




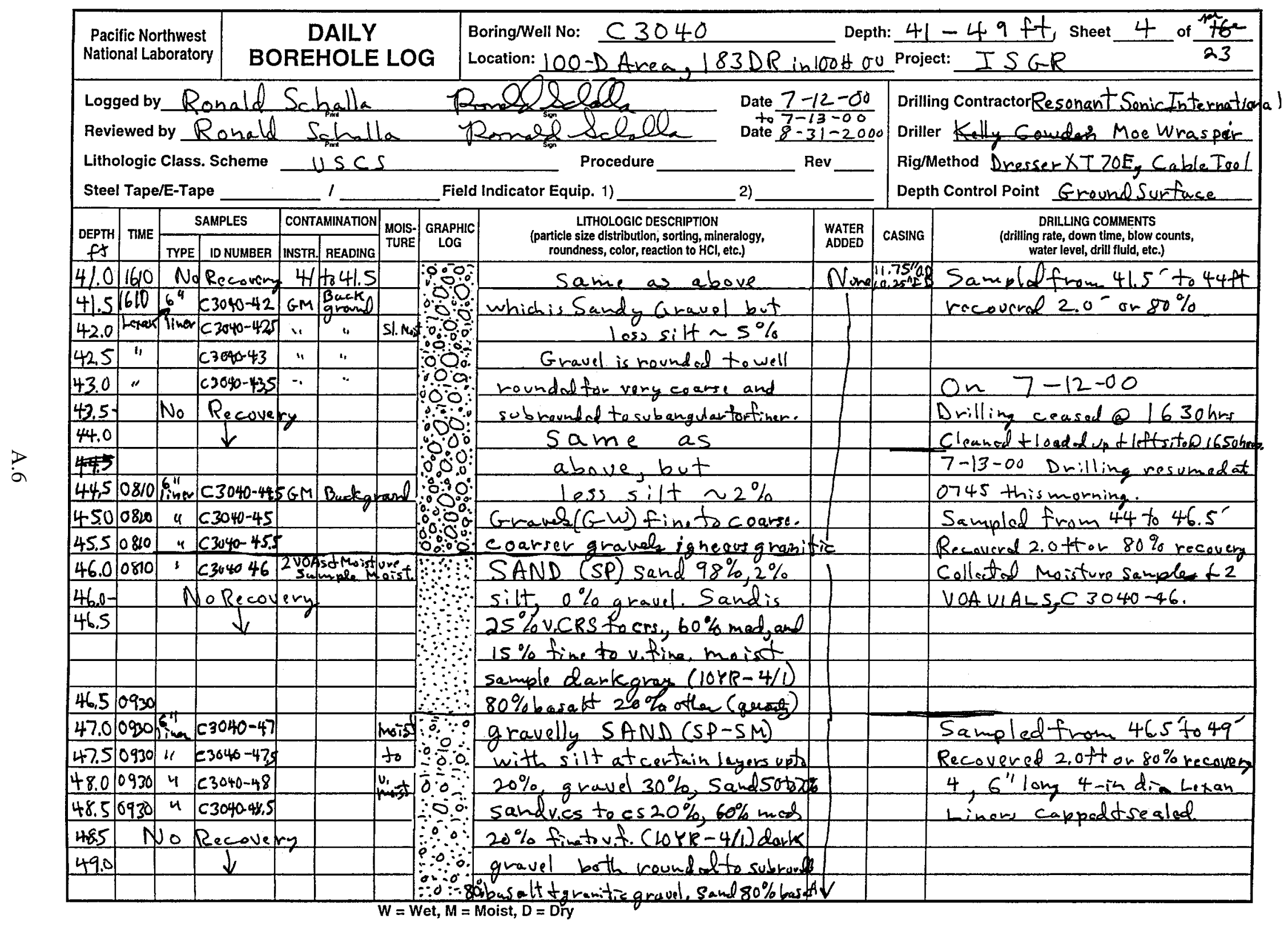




\begin{tabular}{|c|c|c|c|c|c|c|c|c|c|c|c|}
\hline \multicolumn{3}{|c|}{$\begin{array}{l}\text { Pacific Northwest } \\
\text { National Laboratory }\end{array}$} & \multicolumn{5}{|c|}{$\begin{array}{c}\text { DAILY } \\
\text { BOREHOLE LOG }\end{array}$} & \multicolumn{4}{|c|}{ 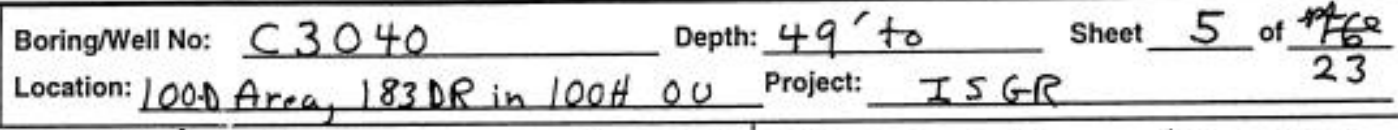 } \\
\hline \multicolumn{7}{|c|}{$\begin{array}{l}\text { Logged by Ronald Schalla } \\
\text { Reviewed by Ronald Senchalla }\end{array}$} & $\frac{y}{y}$ & 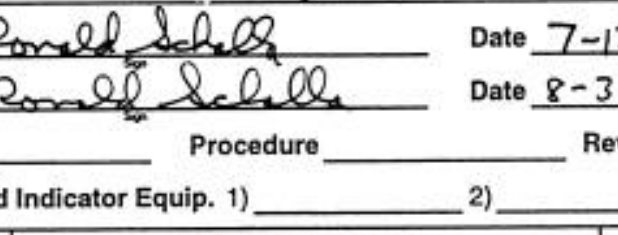 & $\frac{-13-00}{\frac{13-00}{31-00}}$ & \multicolumn{2}{|c|}{$\begin{array}{l}\text { Rig/Method Dresser } X T>0 E, \text { Cable Tool } \\
\text { Depth Control Point Ground Surface }\end{array}$} \\
\hline $\begin{array}{l}\text { DEPTH } \\
\text { PH } \\
\end{array}$ & TME & TPPE & SAMPLES & \begin{tabular}{|l} 
CoNTt \\
INSTR.
\end{tabular} & $\begin{array}{l}\text { MINATION } \\
\text { REAONG } \\
\end{array}$ & & $\begin{array}{ll}\text { GRAPHIC } \\
\text { LOG }\end{array}$ & 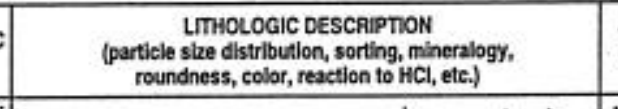 & \begin{tabular}{|l|} 
WATER \\
AOOEO \\
\end{tabular} & CASING & 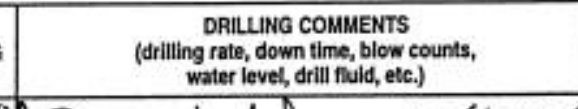 \\
\hline 49.0 & 1118 & & & & & $\pi:$ & $\because 0$ & same as above, bot & None & 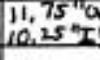 & Sampled from $4 g^{\prime}$ to 51,5 \\
\hline 49.5 & 1118 & 6 Lingrf & C $3040-495$ & $G M$ & Bedpen. & & $\because$ & gravel very fine aun & & & Recovird $=2.0 \mathrm{ft}$ or $80 \%$ of \\
\hline 50,0 & 1118 & " & $c 3040-50$ & & & $\mu_{0} ;$ & $\because$ & less than $10 \%,+22 \%$ silt & & & Sample, 4 6"long, 4-in, \\
\hline 50.5 & 1118 & $"$ & c $3040-50.5$ & & fand & $+:$ & & Possible content with Hantenf & & & dia teran liness wen \\
\hline$\frac{51.0}{-10}$ & 1148 & "l & C3040-51 & $\operatorname{Rin}_{i}$ & & Dry sts & 50 & Ringoll Pormation, silty & & & Capped t sealed. \\
\hline STS & No & Ref & covery & $t m$ & & & $\begin{array}{l}0.0 \% \\
60\end{array}$ & 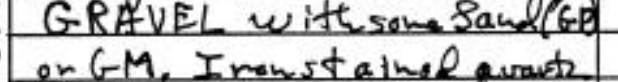 & & & $\begin{array}{l}\text { All sampling from } 24 \text { foed to } \\
\text { to talderth or water is to }\end{array}$ \\
\hline 51,5 & & & & & & & 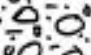 & gravel prominat tother & & & be doner by splits pooun only. \\
\hline 52.0 & 1155 & 6" & c3040-52 & GM & Nowe & Dy 10. & 0.0 & & & & Sampled from $51,5^{\prime}$ to $54^{\prime}$ \\
\hline$\frac{52.5}{5.5}$ & 1155 & finines: & C 3040,525 & an & 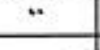 & Dn & 00 & $\operatorname{ray}(10 y k-7 / 2)$ & & & Recoverd $2 \mathrm{ft}$ or $80 \%$ but \\
\hline $52.5-1$ & $N$ & & Recoven & bes & 政e of & & 00 & Rounded to woll rounded & & & I frot was sedimet thed \\
\hline & san & ds sil: & bughing & frov & abov & & 28 & quartz gravel d subrounded & & & foll in from above. Prinariy \\
\hline & & & & & & & 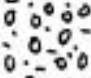 & 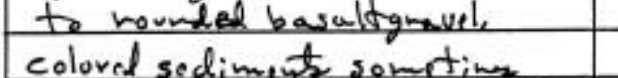 & & & dank gray sand. \\
\hline & & & & & & & Da & lighthowmish gray $(10$ rr, $-6 / 2)$. & & & \\
\hline 54,0 & $13 / 0$ & Sinenter & & & & slisis: & & dy GRAVEL (GM) & & & Split s poon Sampleatrom \\
\hline 54.5 & 1310 & 4 & C3040-575 & $G M$ & None & Maind. & 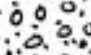 & $50 \%$ og navel, $40 \%$ sand, $10 \%$ ositf & & & 54 to 56.5 - Recoucral 4 \\
\hline$\frac{55,0}{55,5}$ & 1310 & " & c 3040-55 & $\therefore$ & 1 & Moits: & & gravel $5 \%$ orless crs, $20 \%$ madivas & & & $6^{\text {"long }} 4^{\prime \prime} \mathrm{d}$ is Lexantina \\
\hline$\frac{55,5}{56,0}$ & $13 / 0$ & $\because$ & $c 3040-555$ & $\because$ & 4 & & $\because 0=0$ & \% verg fine. & & & foll, $\approx 80 \%$ recovery. 54 to56! \\
\hline 56.5 & $N_{0}$ & $R_{0}$ & Covolo-36 & ${ }^{\circ}$ & & & $0=0$ & \begin{tabular}{|l|} 
ginuel sub rounded to wall hounde \\
in fine to cane sizc. Primar.
\end{tabular} & & & \\
\hline & & & & & & & 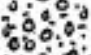 & colorg gry $(104 R-6 / 1)$ but small & & & \\
\hline & & & & & & & 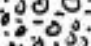 & elored reddish & & & \\
\hline & & & & & & & & & $v$ & & \\
\hline
\end{tabular}




\begin{tabular}{|c|c|c|c|c|c|c|c|c|c|c|c|}
\hline \multicolumn{3}{|c|}{$\begin{array}{l}\text { Pacific Northwest } \\
\text { National Laboratory }\end{array}$} & \multicolumn{5}{|c|}{$\begin{array}{l}\text { DAILY } \\
\text { BOREHOLE LOG }\end{array}$} & \multicolumn{4}{|c|}{ 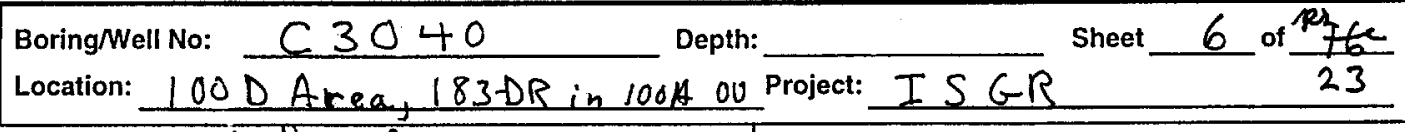 } \\
\hline \multicolumn{4}{|c|}{$\begin{array}{l}\text { Logged by Ronald } \\
\text { Reviewed by Ronald } \\
\text { Lithologic Class. Scheme } \\
\text { Steel Tape/E-Tape }\end{array}$} & $\frac{d s}{d s}$ & $\begin{array}{l}\text { Scha } \\
\text { Spena } \\
\text { Sche } \\
\text { US } \\
\end{array}$ & $\begin{array}{l}\text { Ila } \\
\text { csa }\end{array}$ & Field & \multicolumn{2}{|c|}{ 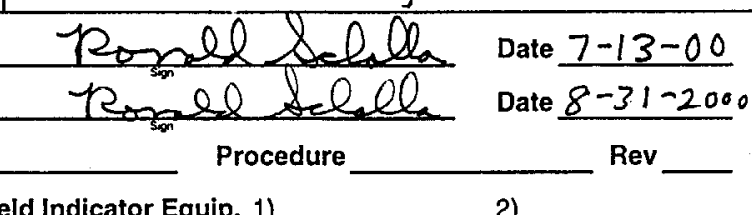 } & \multicolumn{2}{|c|}{$\begin{array}{l}\text { Drilling Contractor Resonant Sonic Internden } \\
\text { Driller Morris "Moe" Wraspir } \\
\text { Rig/Method DresserXT70E, CableTod } \\
\text { Depth Control Point Ground Surtace }\end{array}$} \\
\hline DEPTH & TIME & \multicolumn{2}{|c|}{ SAMPLES } & \multicolumn{2}{|c|}{ CONTAMINATION } & MOIS- & $\begin{array}{c}\text { GRAPHIC } \\
\text { LOG }\end{array}$ & $\begin{array}{l}\text { LTHHOLOGIC DESCRIPTION } \\
\text { (particle size distributtion, sotrting, mineralogy, } \\
\text { roundness, color, reaction to HCl, etce). }\end{array}$ & $\begin{array}{l}\text { WATER } \\
\text { ADDED } \\
\end{array}$ & CASING & $\begin{array}{l}\text { DRILLING COMMENTS } \\
\text { (drilling rate, down time, blow counts, } \\
\text { water fevel, drill fluld, etc.) }\end{array}$ \\
\hline 56.5 & 1450 & (1) & Winomon & & nemulas & & $\because 00.9$ & Same as above, & None & & Split spoom samplod from 56., \\
\hline 57,0 & 1450 & 69 & C 3040.5 & & & sligin & 400 & but maves ilt perhaps & & & to 5R.Q' Recouserd four \\
\hline 57,5 & 1450 & 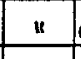 & $(3040-925$ & & & or & $\div 0=0$ & as much as $30 \%$ ot & & & 6 -in. Long Lexau liners fulll, \\
\hline 58.0 & 1450 & $\because 1$ & $63040-58$ & & & $2 n$ & 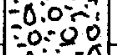 & certain Loyen, Mayl & & & $\sim 80 \%$ vecousry $56.5^{\circ}$ to 58.5 \\
\hline 58.5 & 1450 & 4 & $c 3040-525$ & & & & $=0.0$ & slightly canoted & & & \\
\hline 59,0 & No & Rec. & sueng 58 & $5 t_{0}$ & $59^{\prime}$ & & $10 \div 00$ & & & & \\
\hline 59,0 & 1520 & & & & & & 0 & & & & \\
\hline 59,5 & 1520 & 6" & $c 3040-60$ & & & & $=0-00000$ & Same ar aboure but & & & Samplew by split speow 4" \\
\hline 60.0 & 1520 & Lime & $C 3040605$ & & & 31. & $\mid \begin{array}{ll}0 \\
0\end{array} 00: 0$ & less silt perhope $10 \%$ & & & dia. 6"long Loxan lines. \\
\hline 60.5 & 1520 & ". & 6304061 & & & Most: & 1000 & orless. & & & Collotel frour 6-in sauph \\
\hline 61.0 & $\sqrt{528}$ & $\therefore$ & $C 3040-61,5$ & & & & 10.0001 & & & & or $80 \%$ recourng. \\
\hline 61.5 & No & Rnct & veng 61 & to 6 & $1.5 \mathrm{AH}$ & & 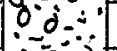 & & & & \\
\hline 61,5 & & & & & & & $\begin{array}{ll}0.0 \\
0.0\end{array}$ & & & & \\
\hline 62.0 & & & $C 3040-62$ & & & 31. & $\because 0^{\circ}$ & Sahe as aboue & & & \\
\hline 62.5 & & $\begin{array}{l}\text { Lexay } \\
\text { Lining }\end{array}$ & $C 304063$ & & & Kont & $\therefore 0$ & & & & \\
\hline 63.0 & & & 0304063 & & & & $00_{6}^{\circ}$ & & & & \\
\hline 635 & & 4 & C $7040-63.5$ & & & & 0.0 & & & & \\
\hline 64.0 & & No & Recovery & & & & $\because 0: 00$ & & & & \\
\hline & & & & & & & & & & & \\
\hline & & & & & & & & & & & \\
\hline & & & & & & & & & & & \\
\hline & & & & & & & & & & & \\
\hline & & & & & & & & & & & \\
\hline & & & & & & & & & & & \\
\hline
\end{tabular}




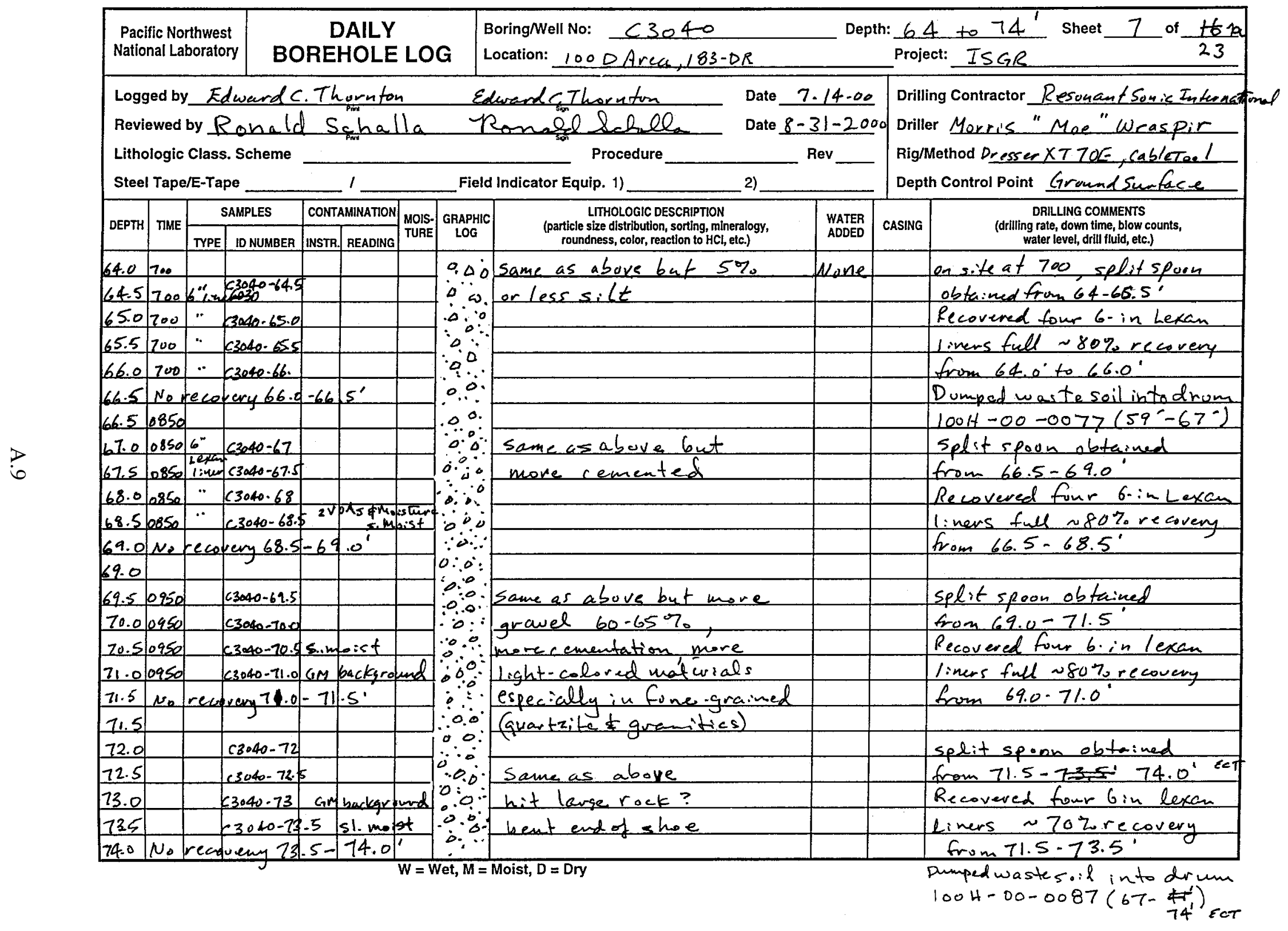




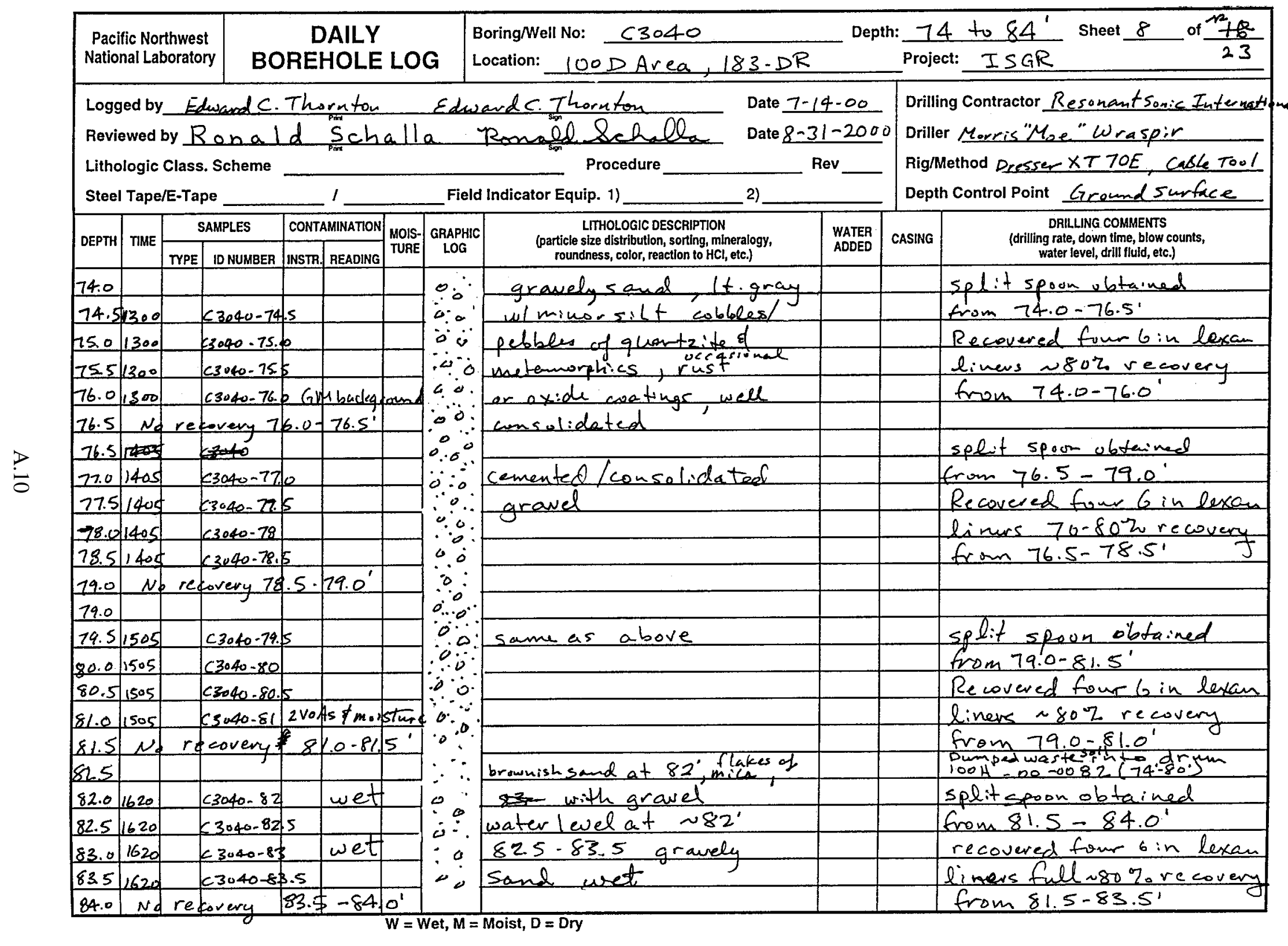




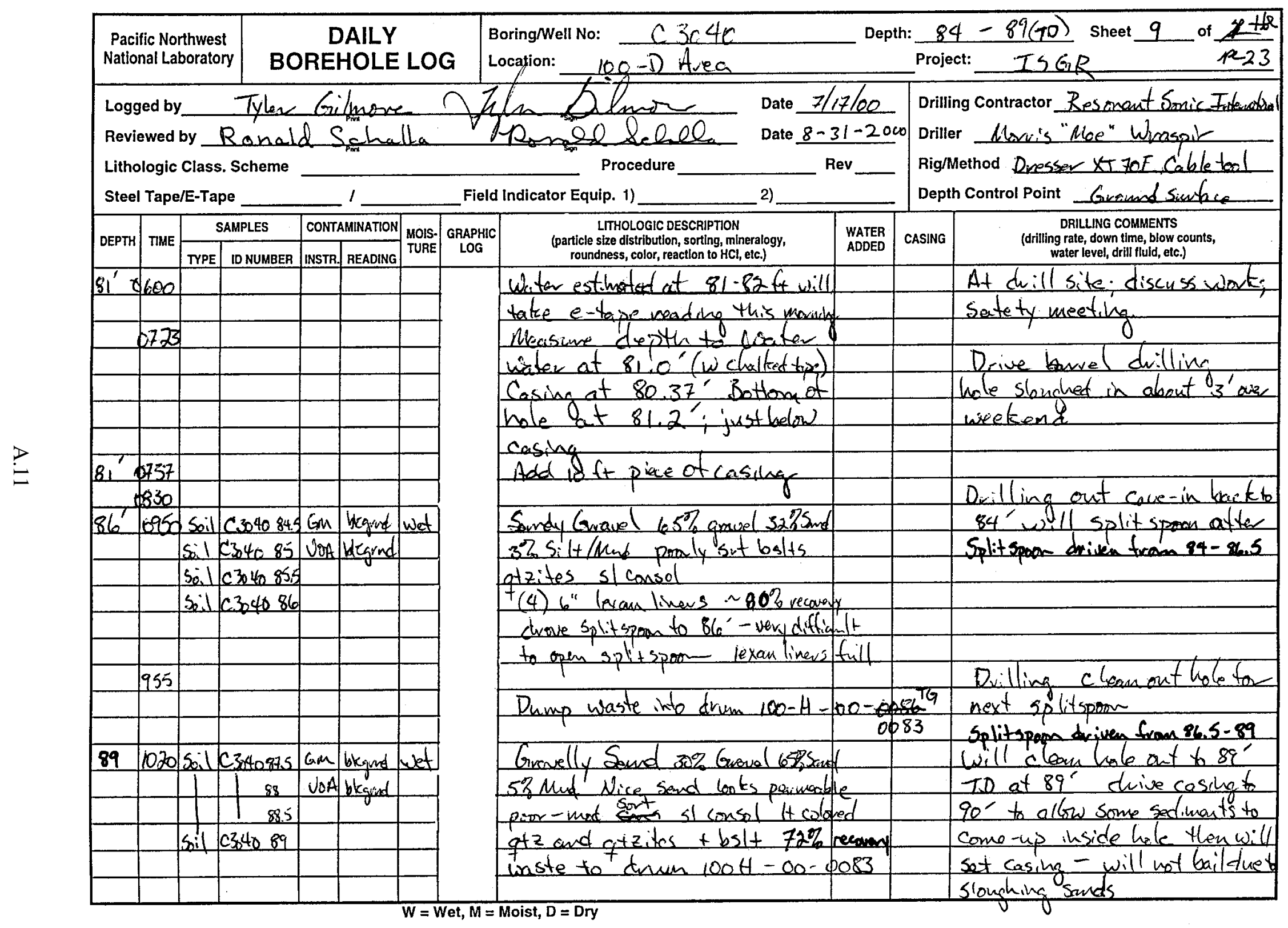




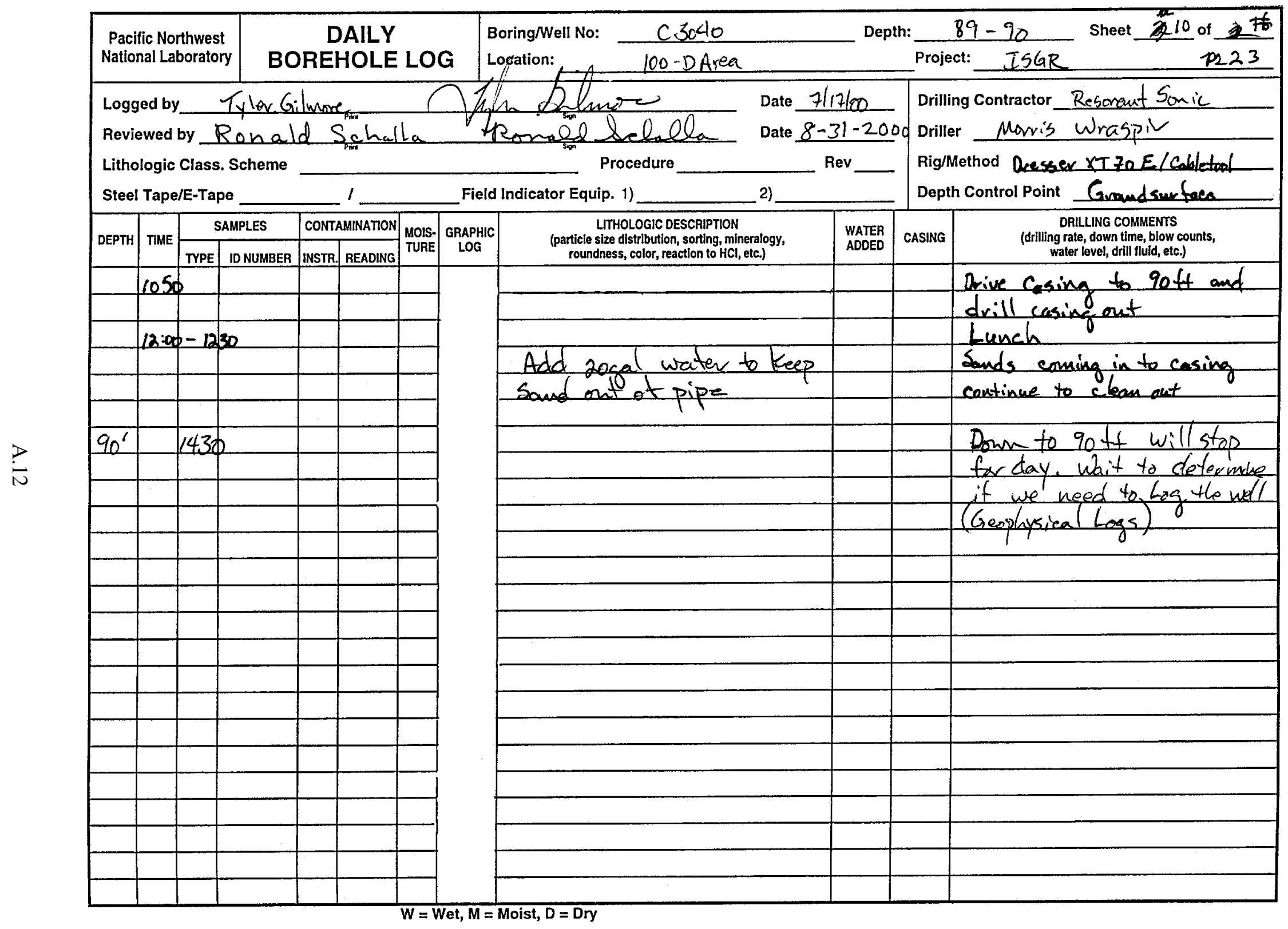




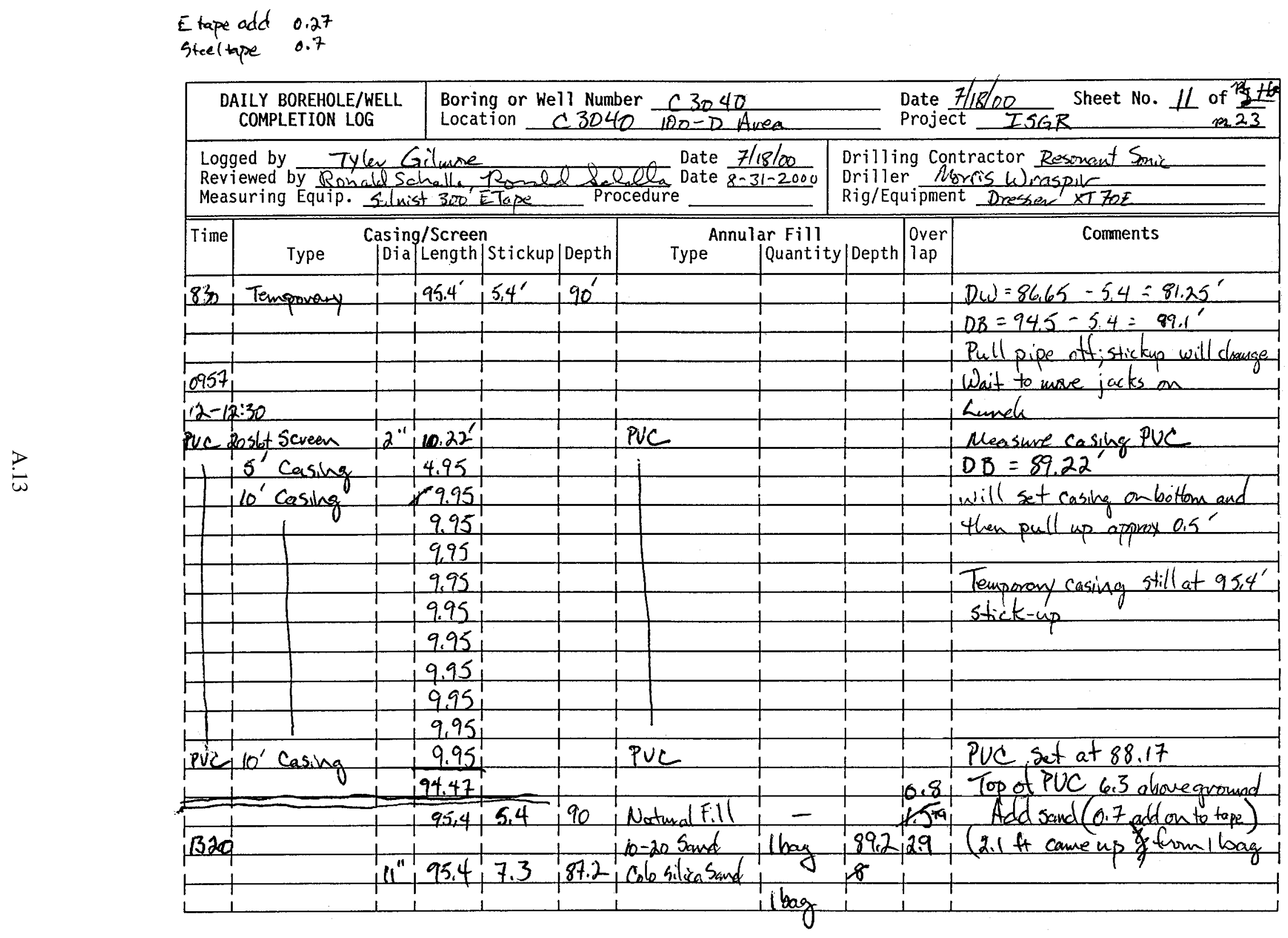




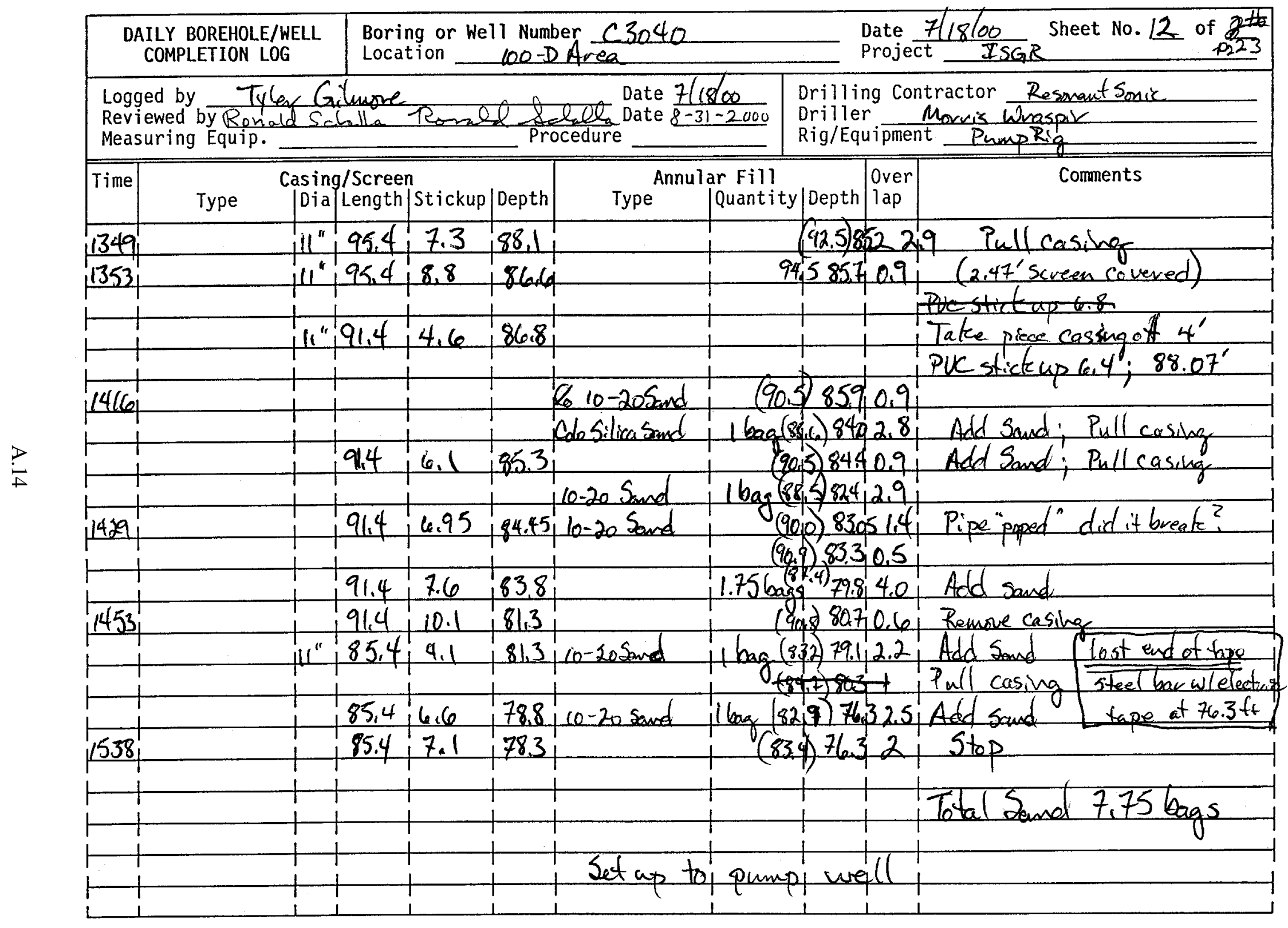




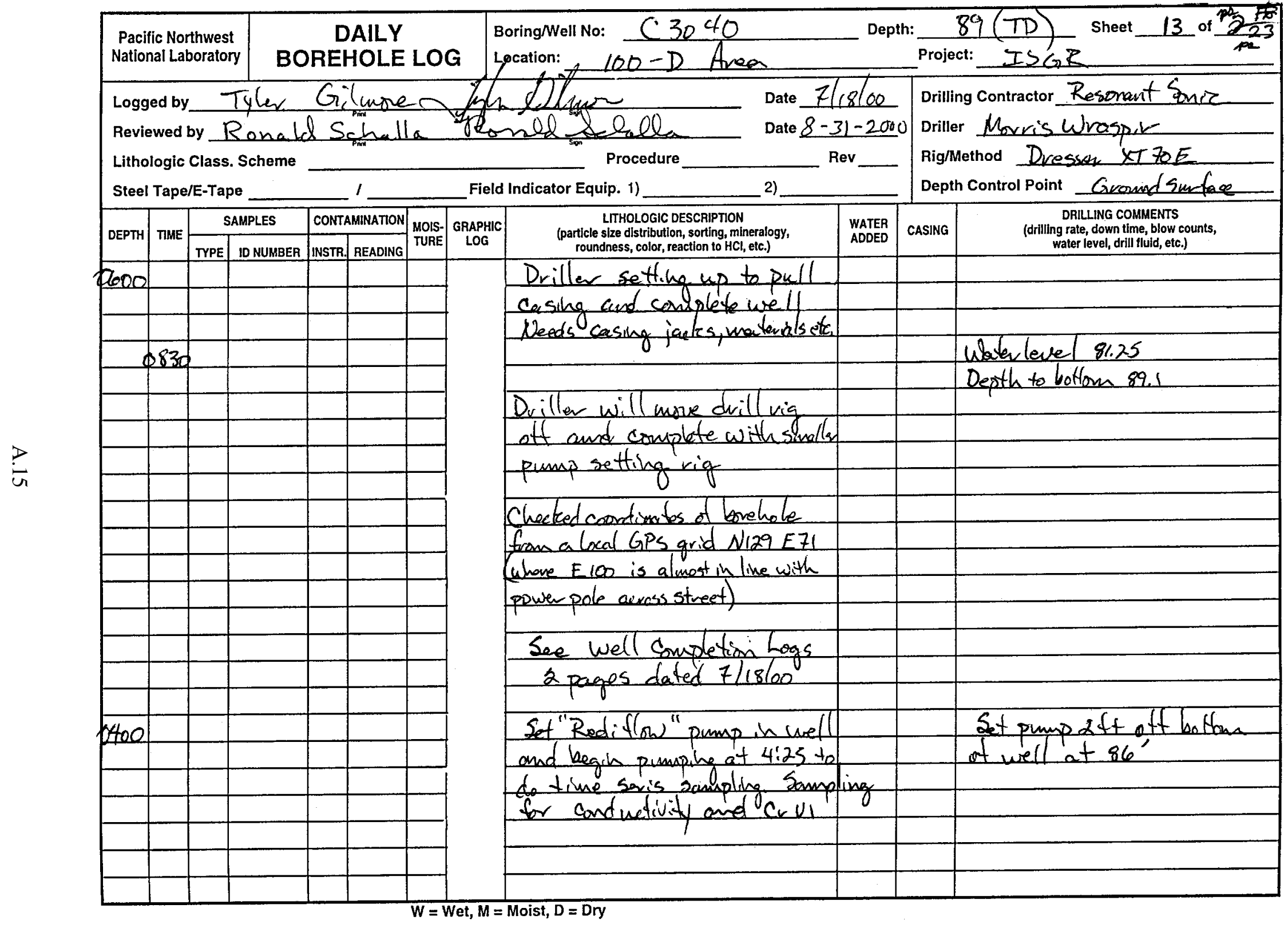




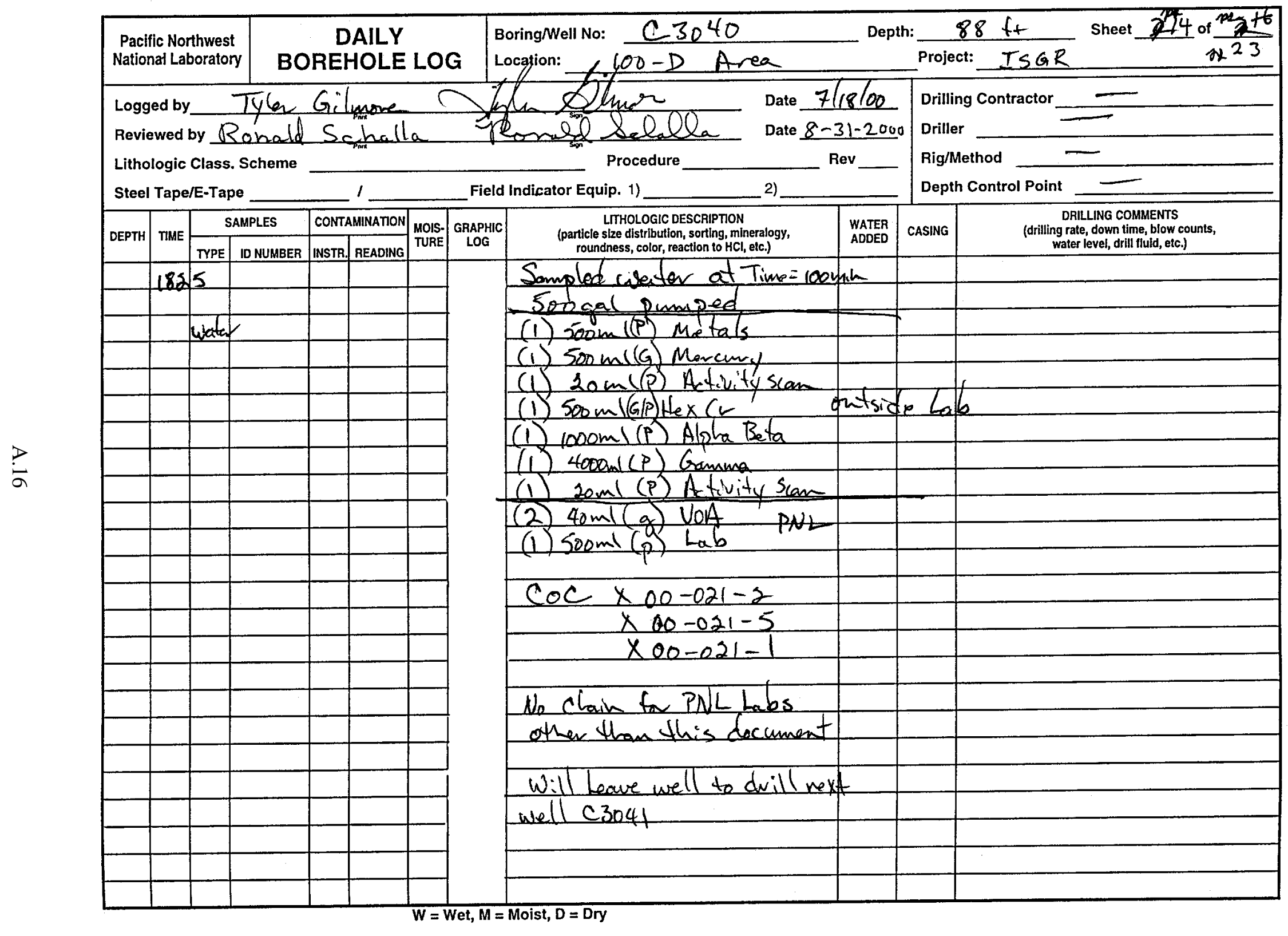




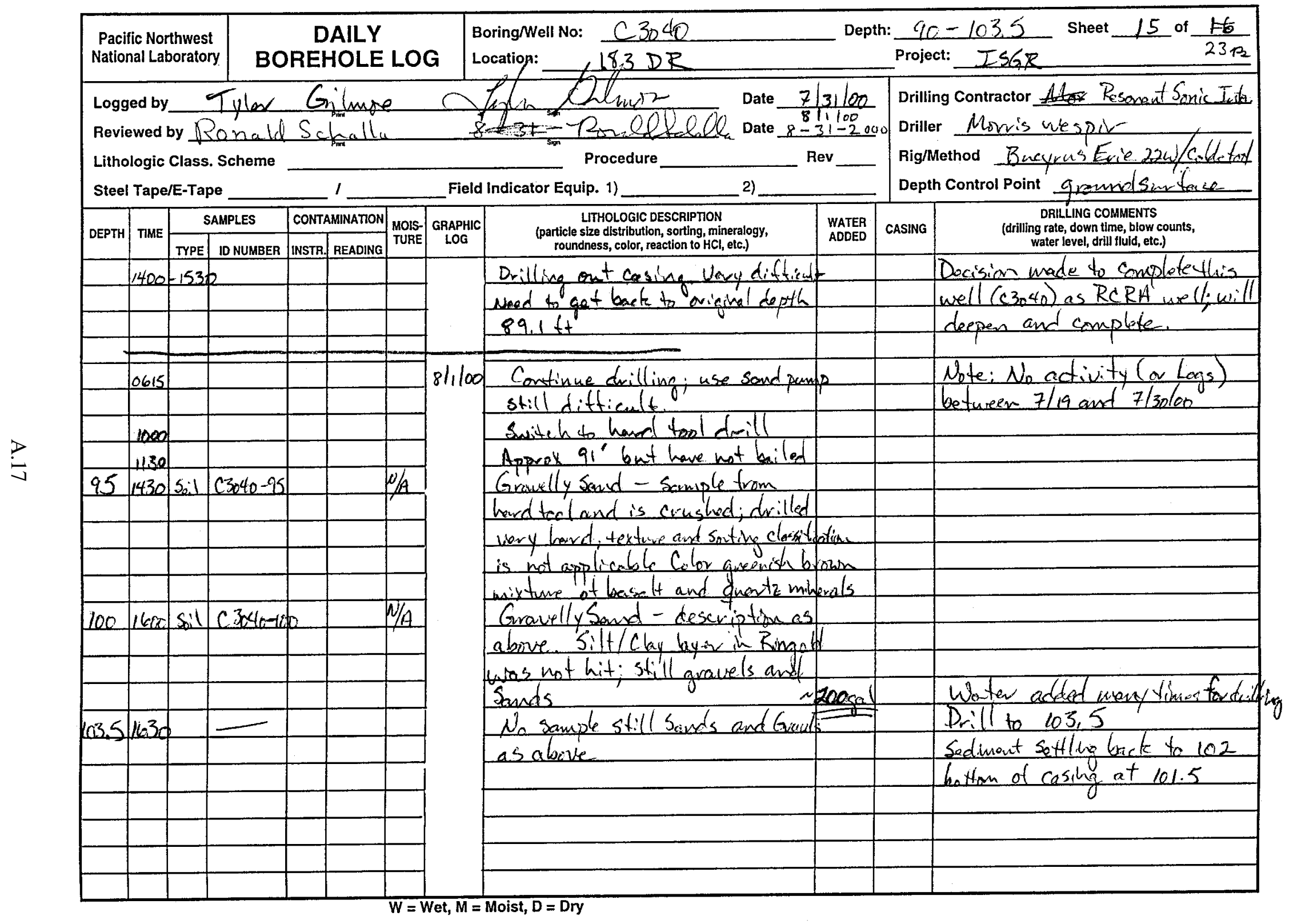




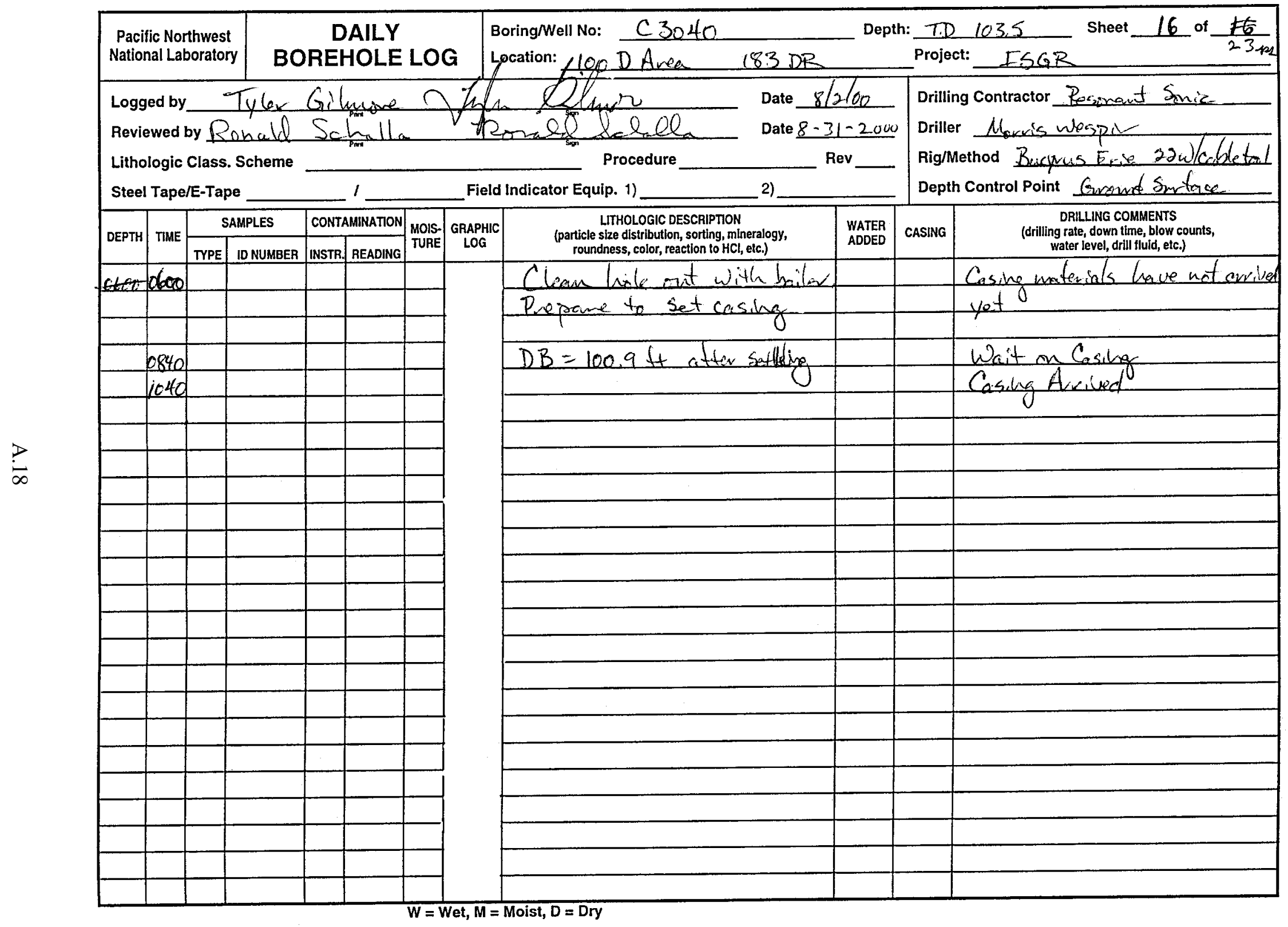




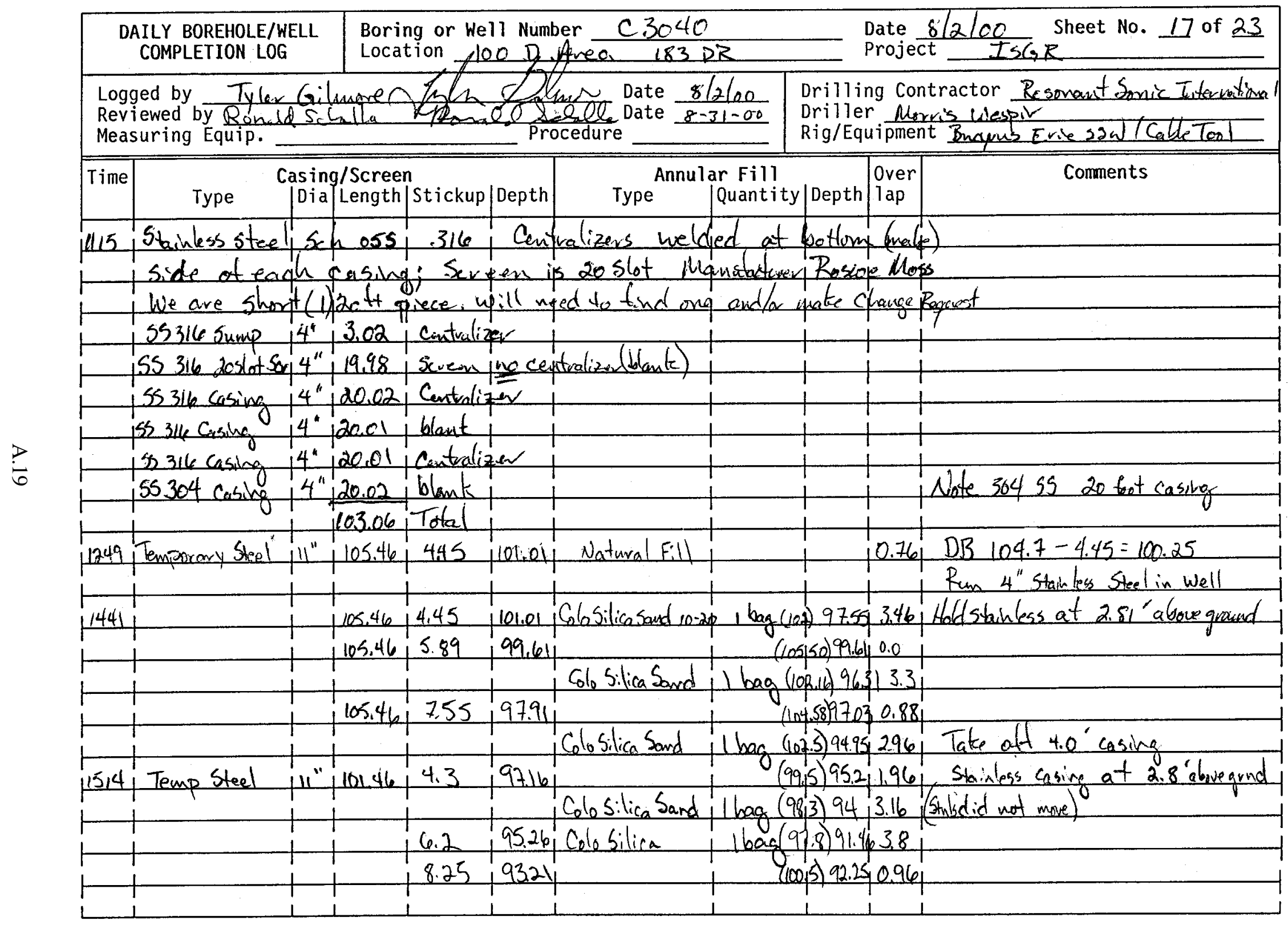




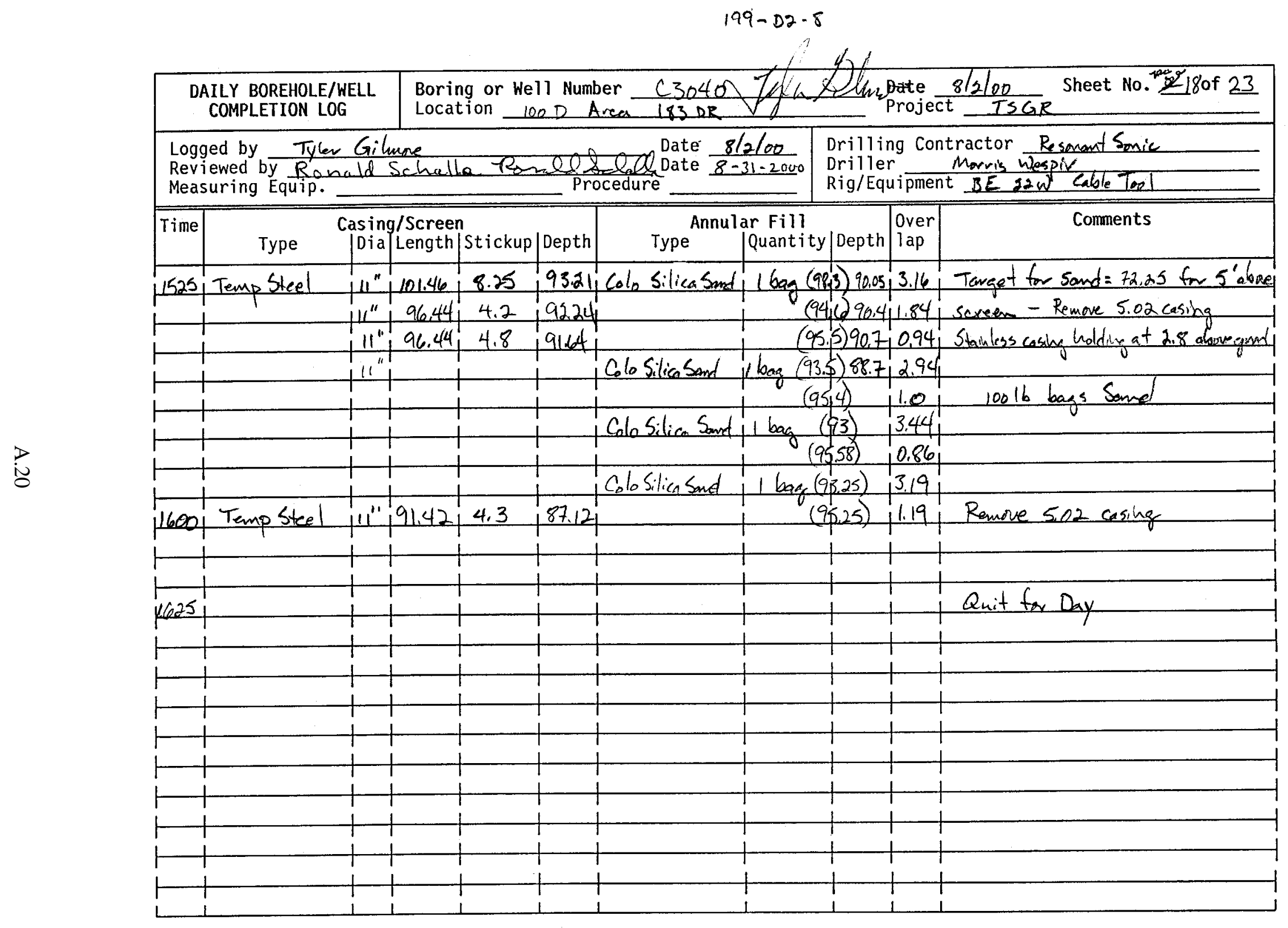




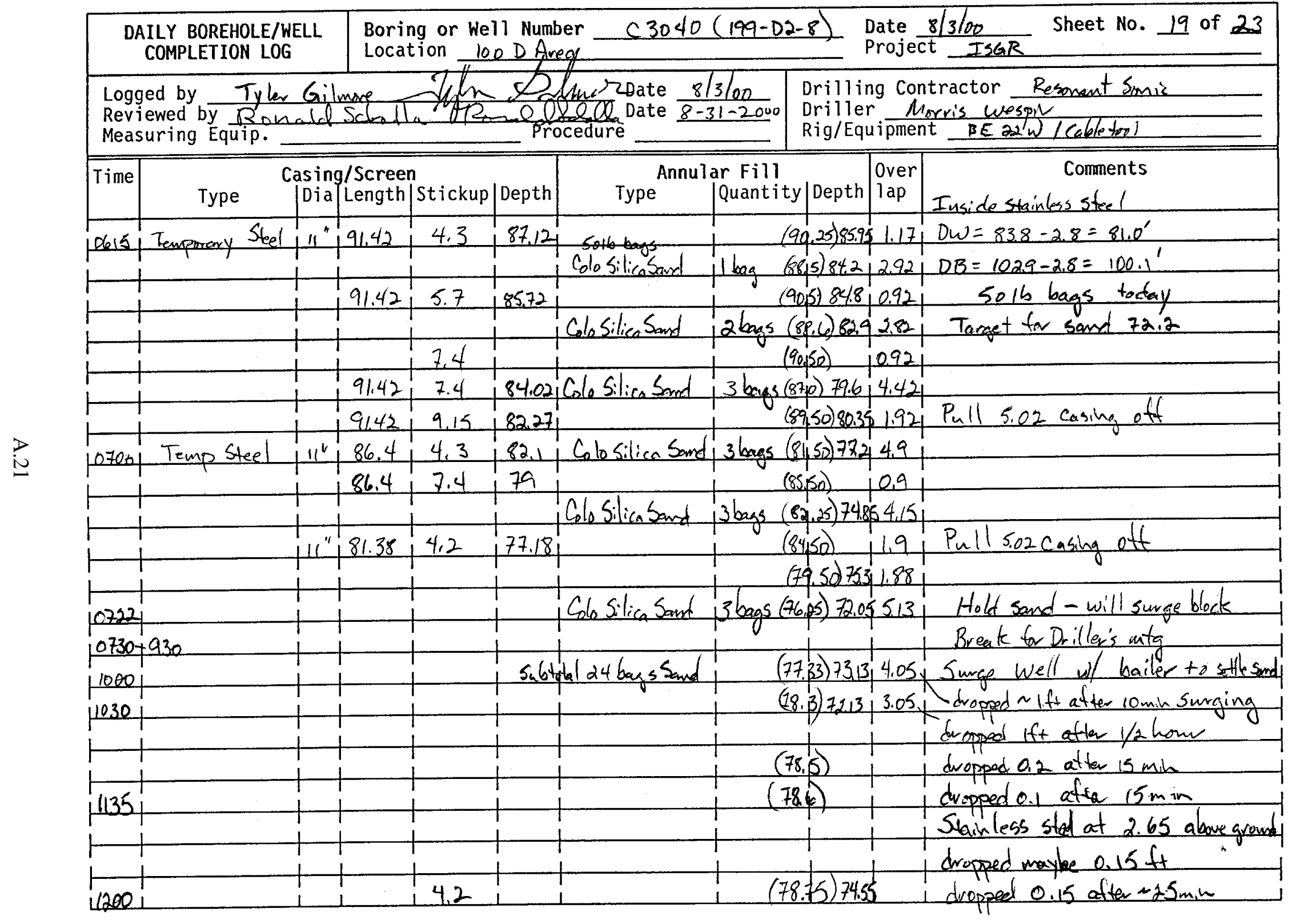




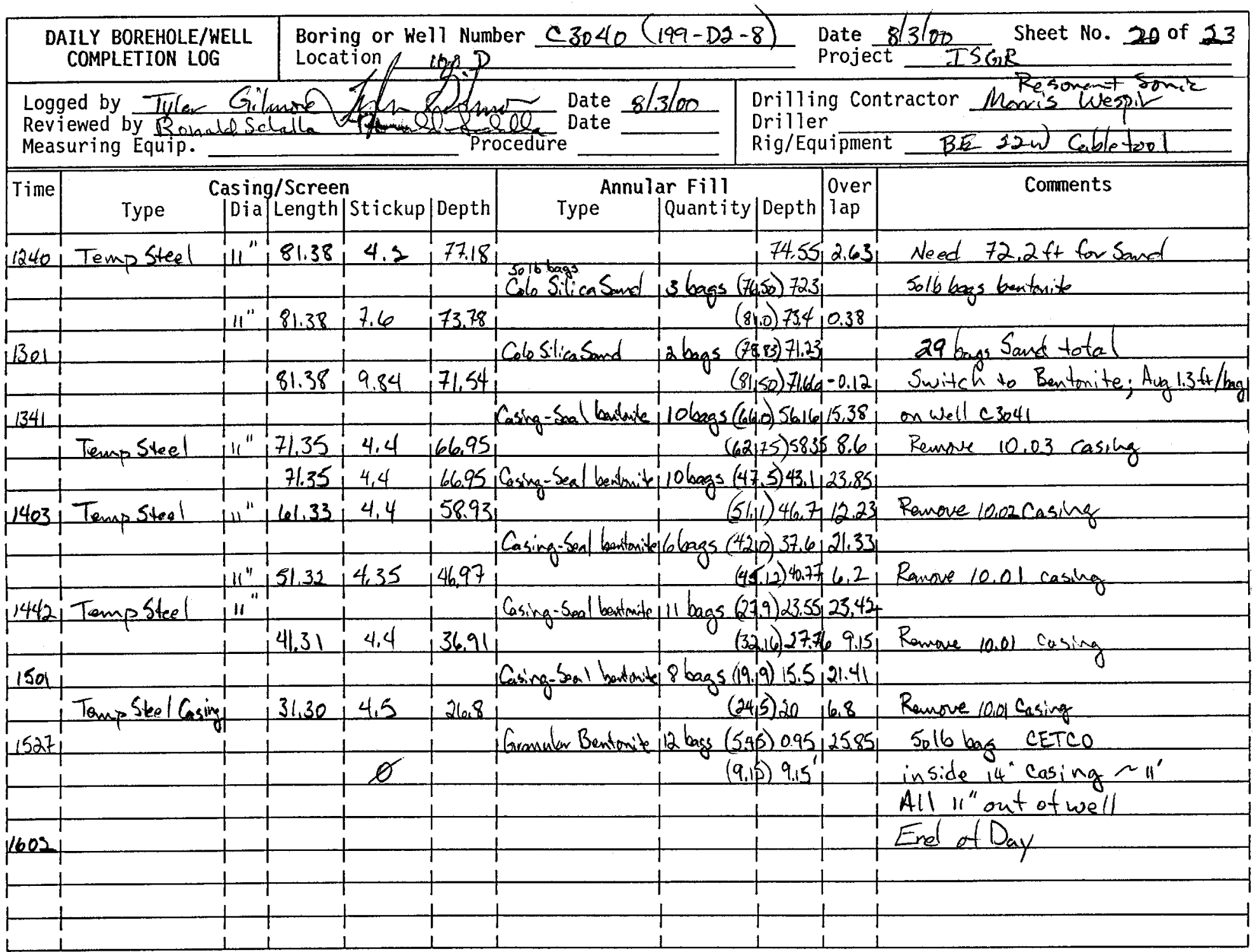




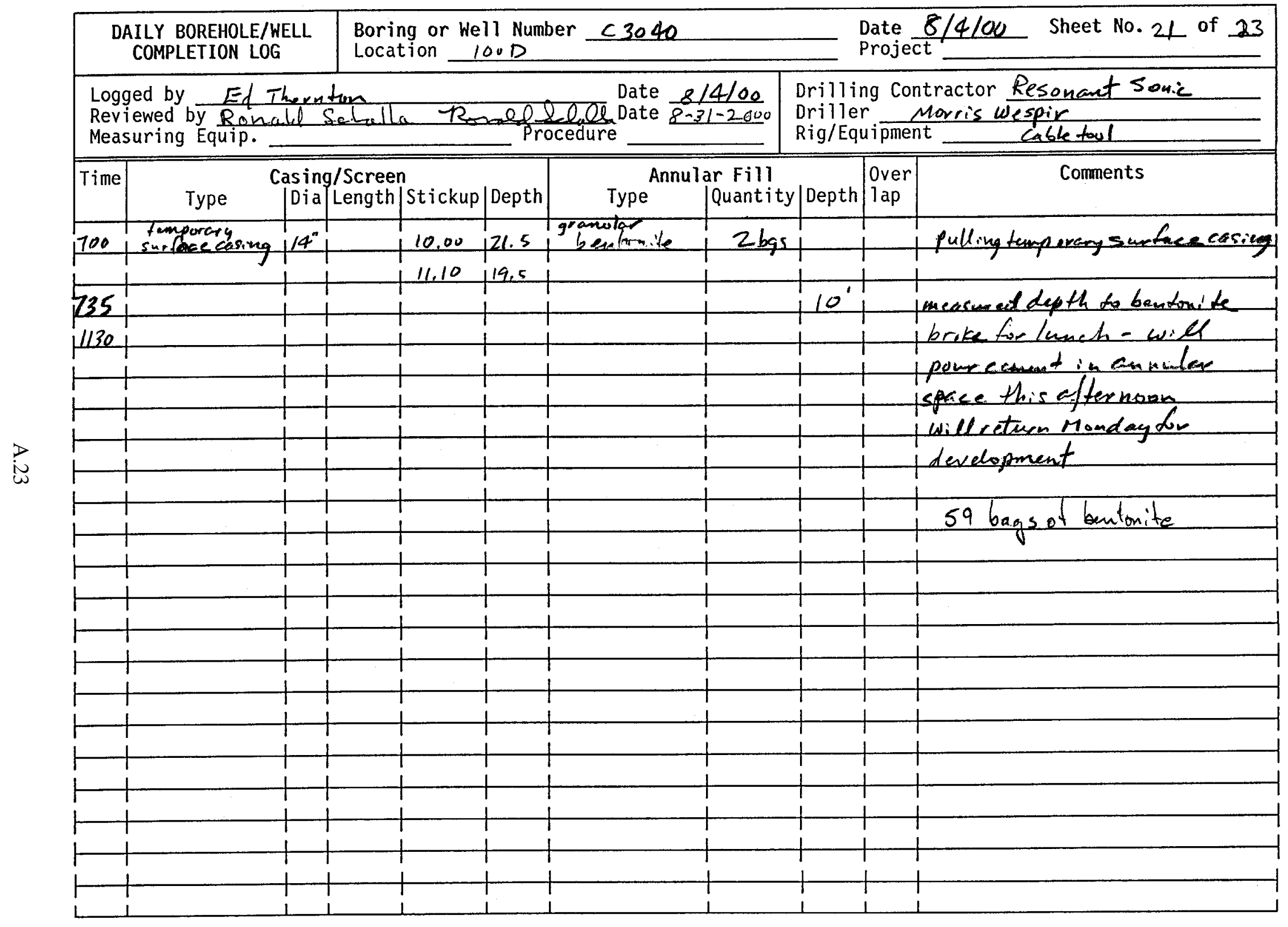




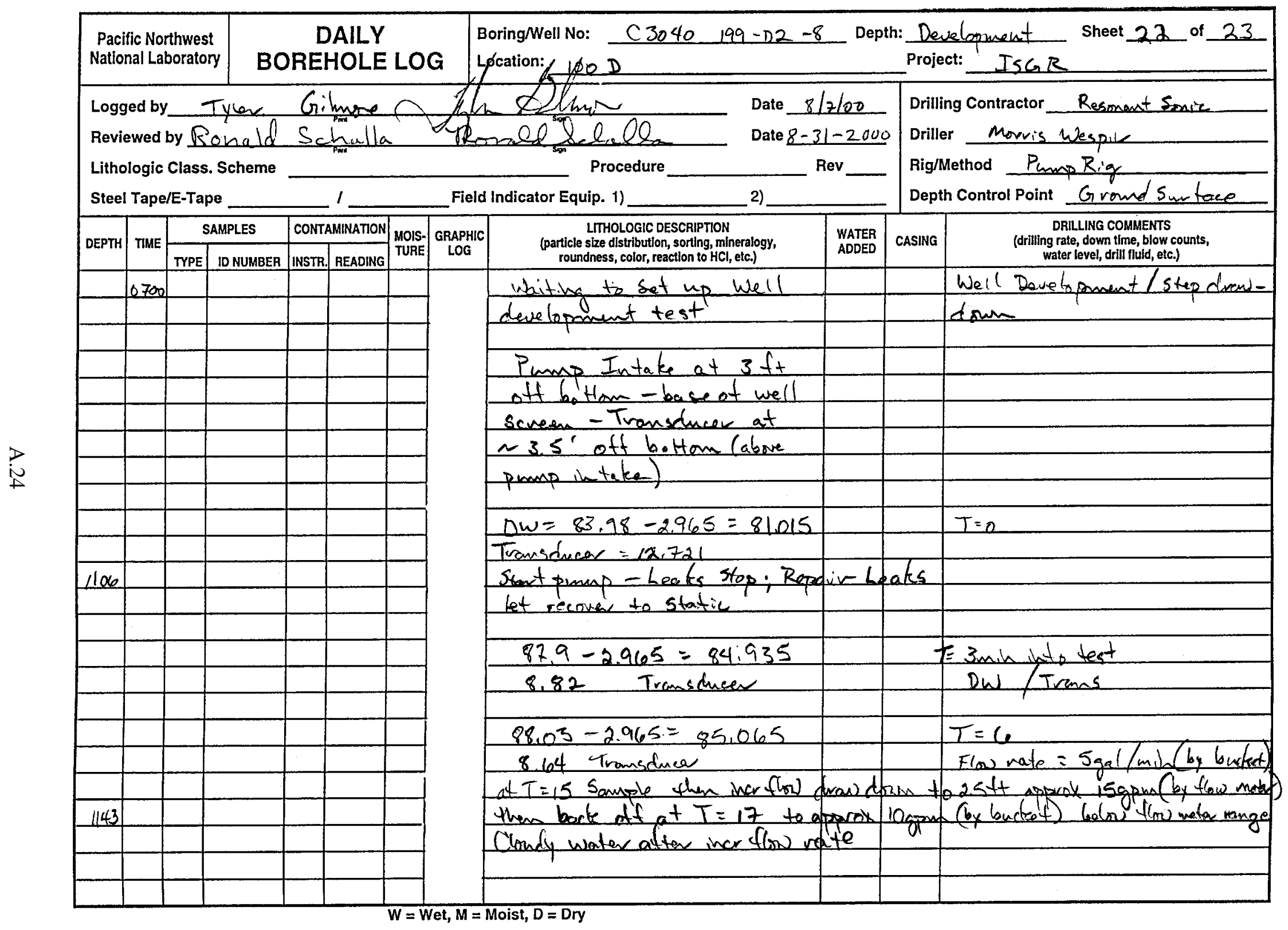




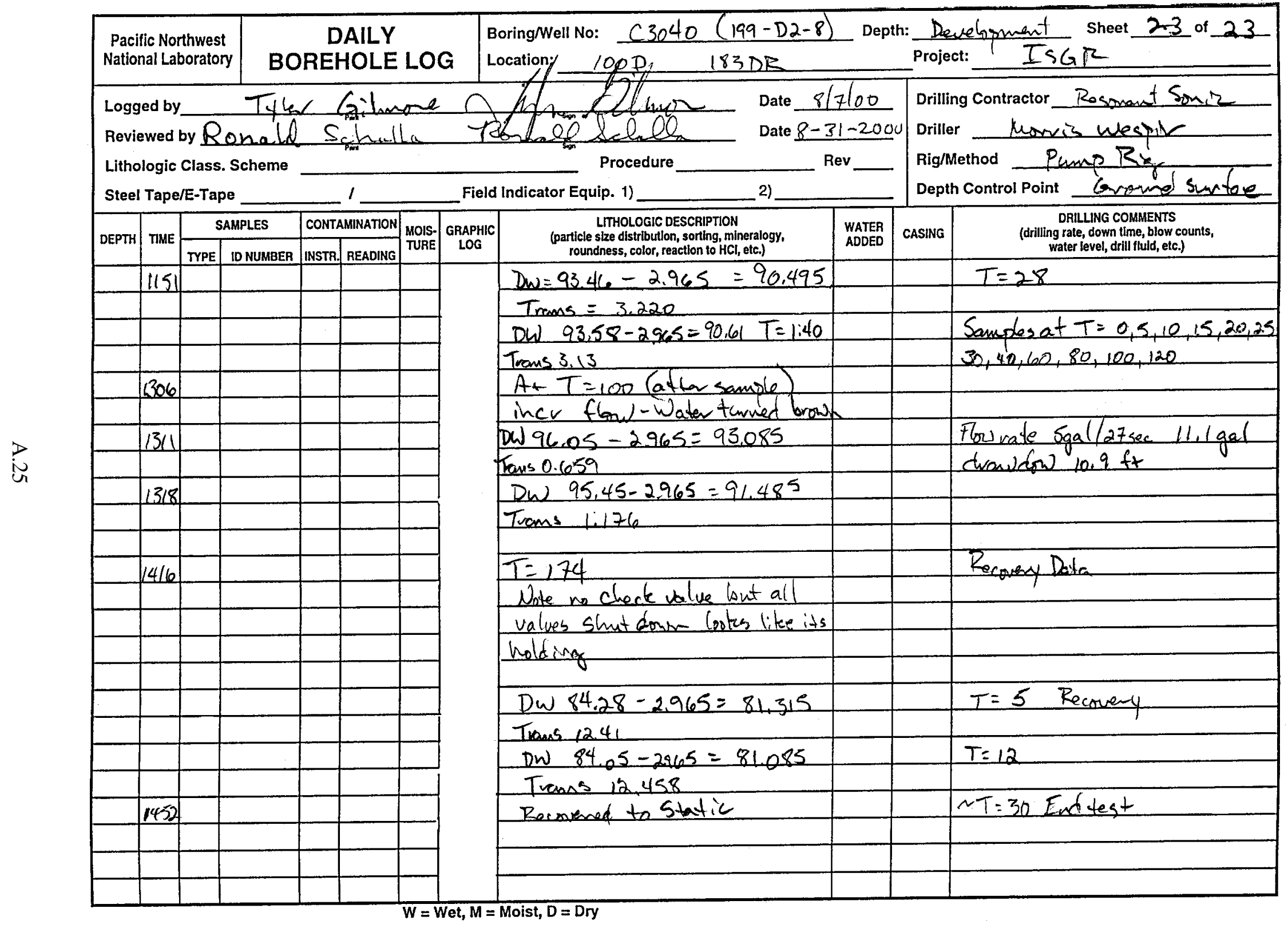




\section{GROUNDWATER SAMPLE REPORT}

Project: 183-DR GW, Drilling Samples, July

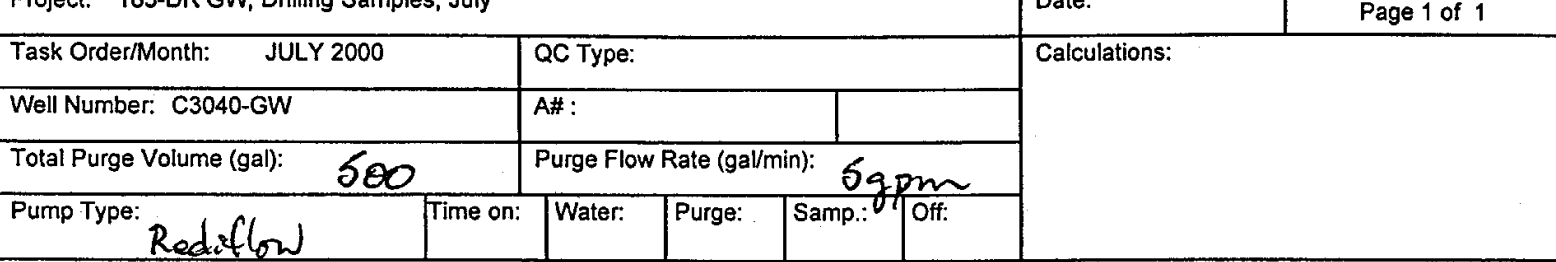

BOYN88 Severn Trent Incorporated

SAMPLES COLLECTED

1;500mL;G/P 7196_CR6: Hexavalent Chromium (1) (Cool 4C)

BOYN89 Severn Trent Incorporated

COC No.: X00-021-1

1;20mL;P Activity Scan (None)

1;4000mL;G/P GAMMA_GS: List-1 (9) (HNO3 to $\mathrm{pH}<2$ )

1:1000mL;P 9310_ALPHABETA_GPC: Alpha + Beta (2) $(\mathrm{HNO}$ to $\mathrm{pH}<2)$

BOYN92

Severn Trent St. Louis

COC No.: $\times 00-021-5$

$1 ; 20 \mathrm{~mL} ; P \quad$ Activity Scan (None)

1;500mL;G 7470_HG_CVAA: Mercury (1) (HNO3 to $\mathrm{pH}<2$ )

1;500mL;P 6010_METALS_ICP: List-1 (19) (HNO3 to $\mathrm{pH}<2$ )

Total No. Bottles: 7

Containment Code:

Collector.

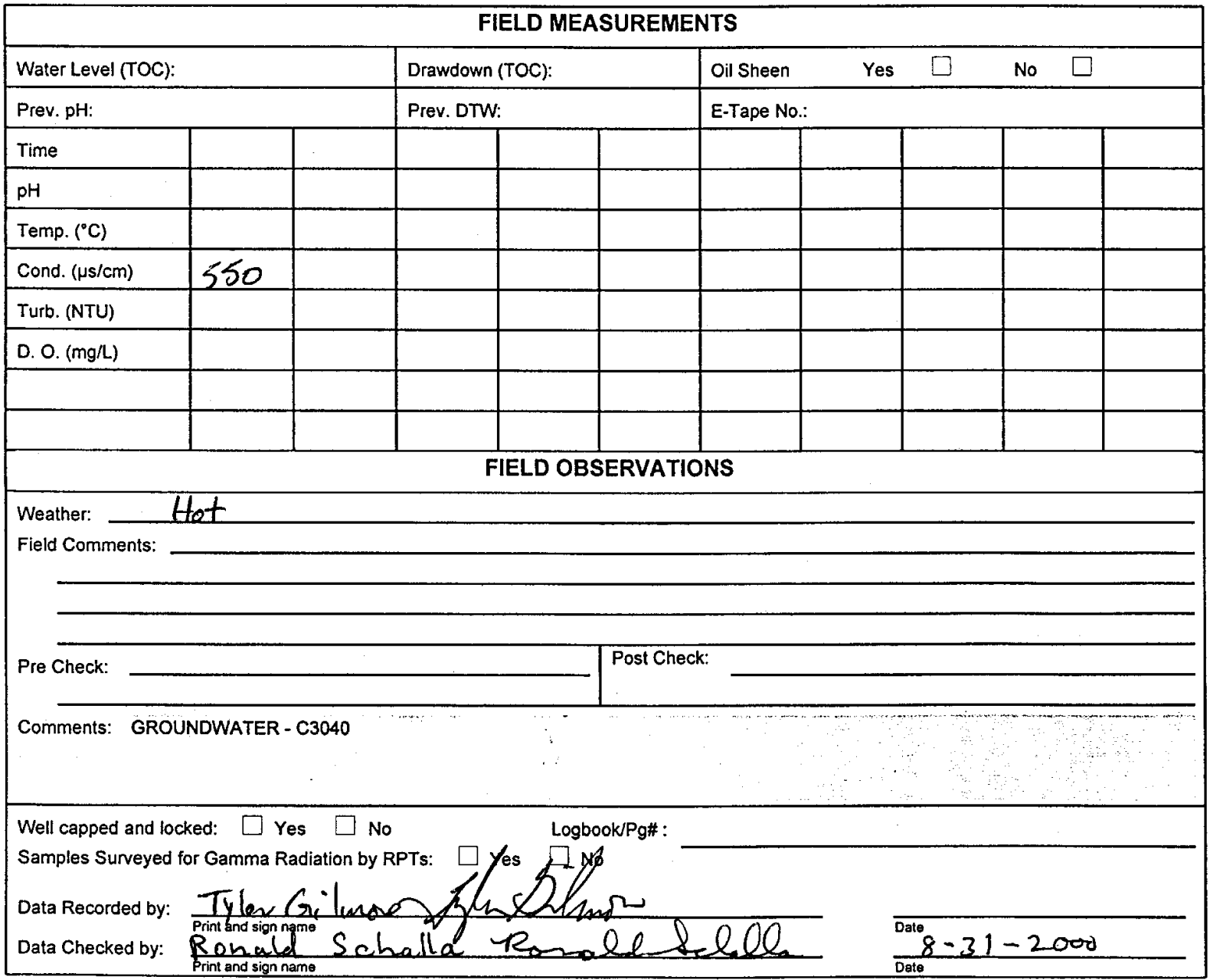




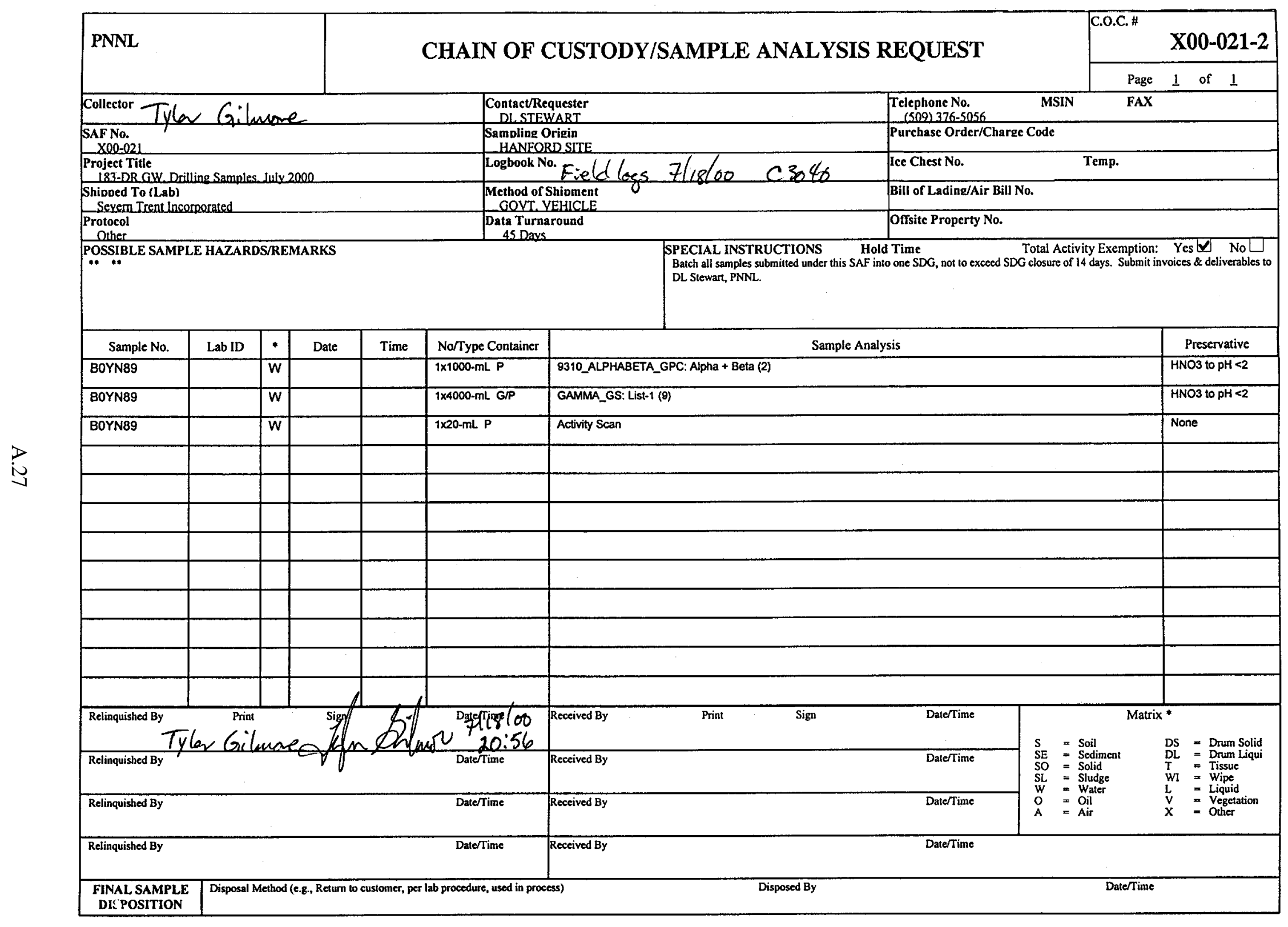


Cr vI

Groundwater

7/18/00 Pumptest C3040

4:30 ran $0.5 \mathrm{mg} / \mathrm{l}$ crvistd - read $0.45 \mathrm{mg} / \mathrm{l}$

4:38 To (filtered) $0.01 \mathrm{mg} / \mathrm{h} \quad \mathrm{cr} V \mathrm{l}$

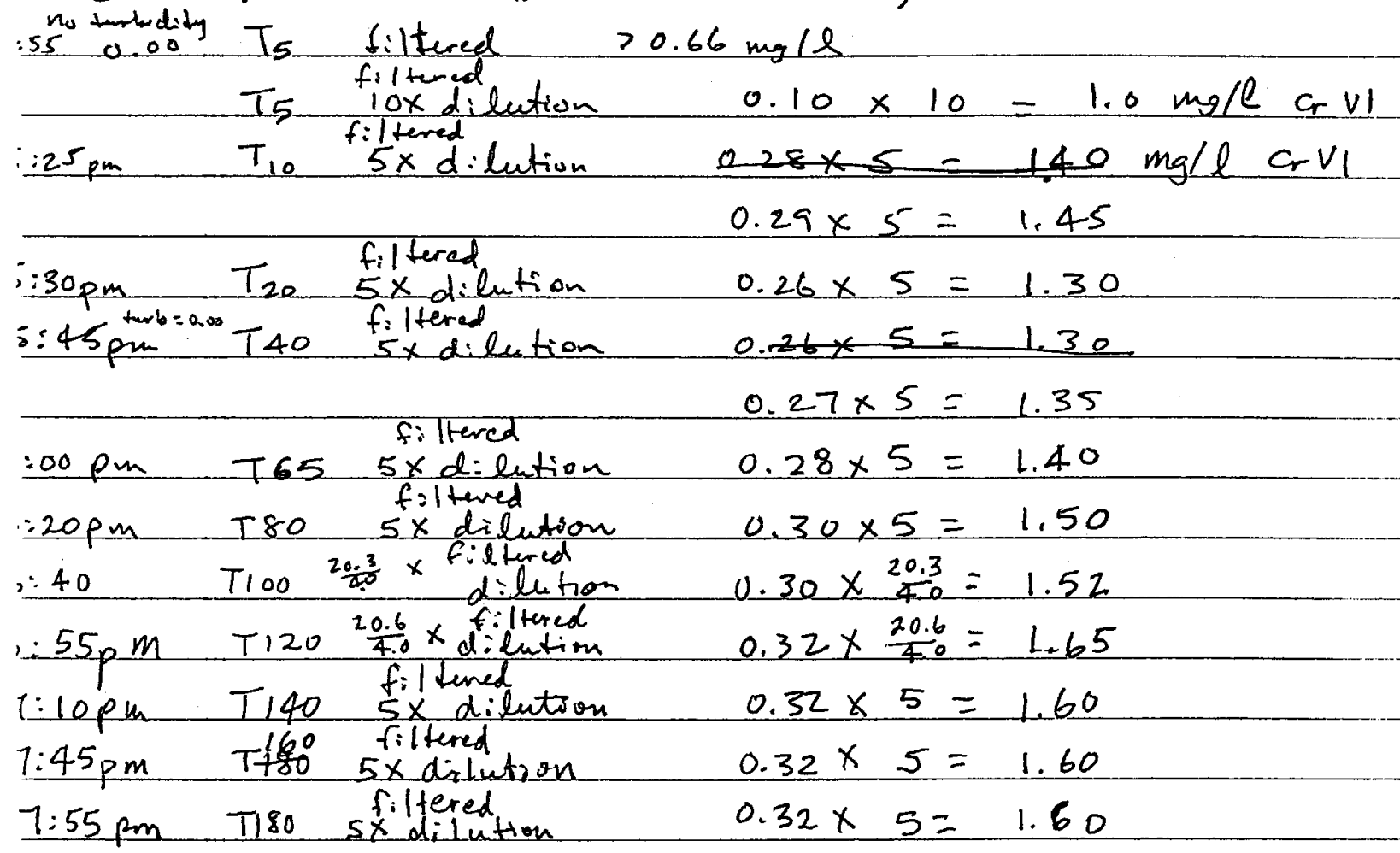

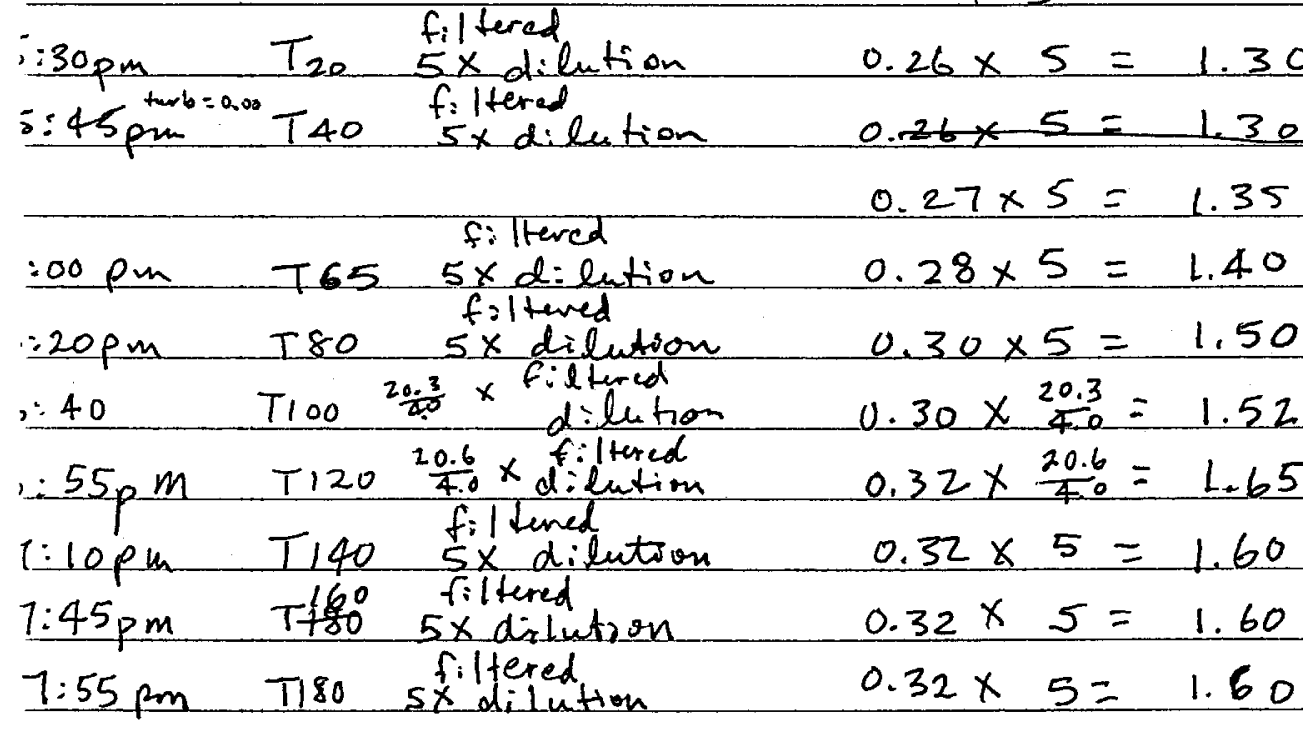

A. 28 


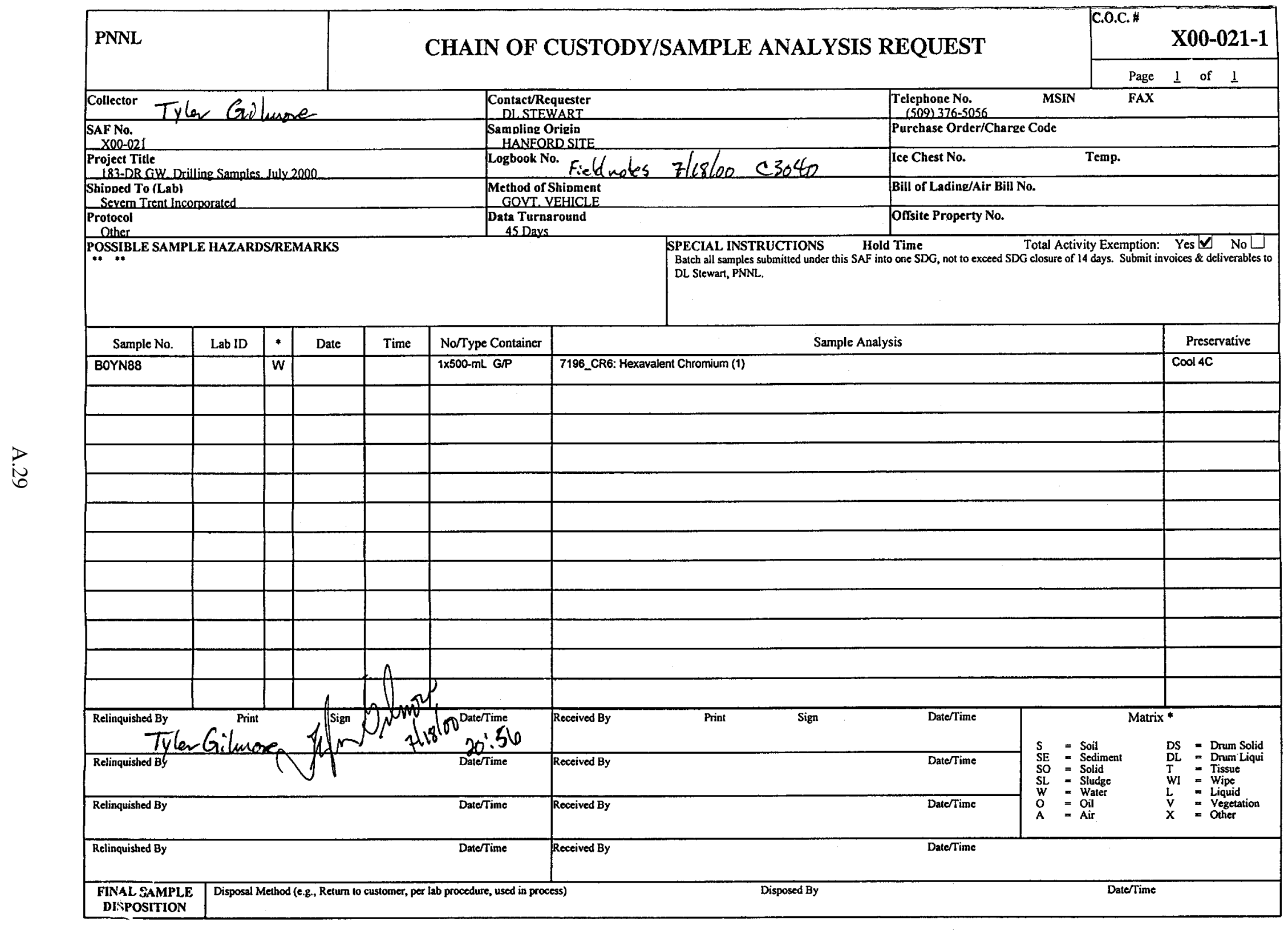




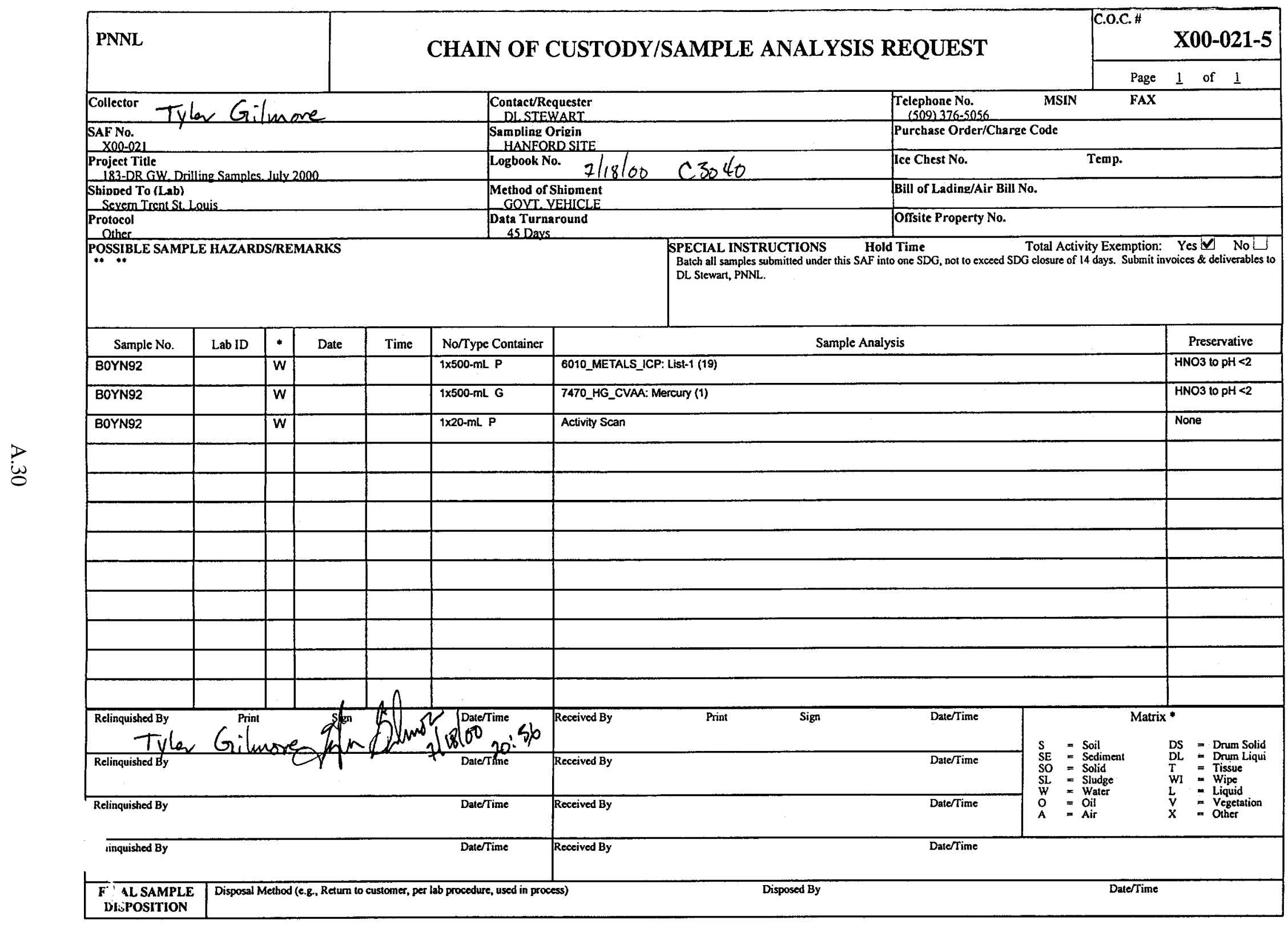




\section{Appendix B}

\section{Well Construction Summary Report, Borehole Log, and}

Geophysical Logs for Borehole C3041 


\section{WELL CONSTRUCTION SUMMARY REPORT}

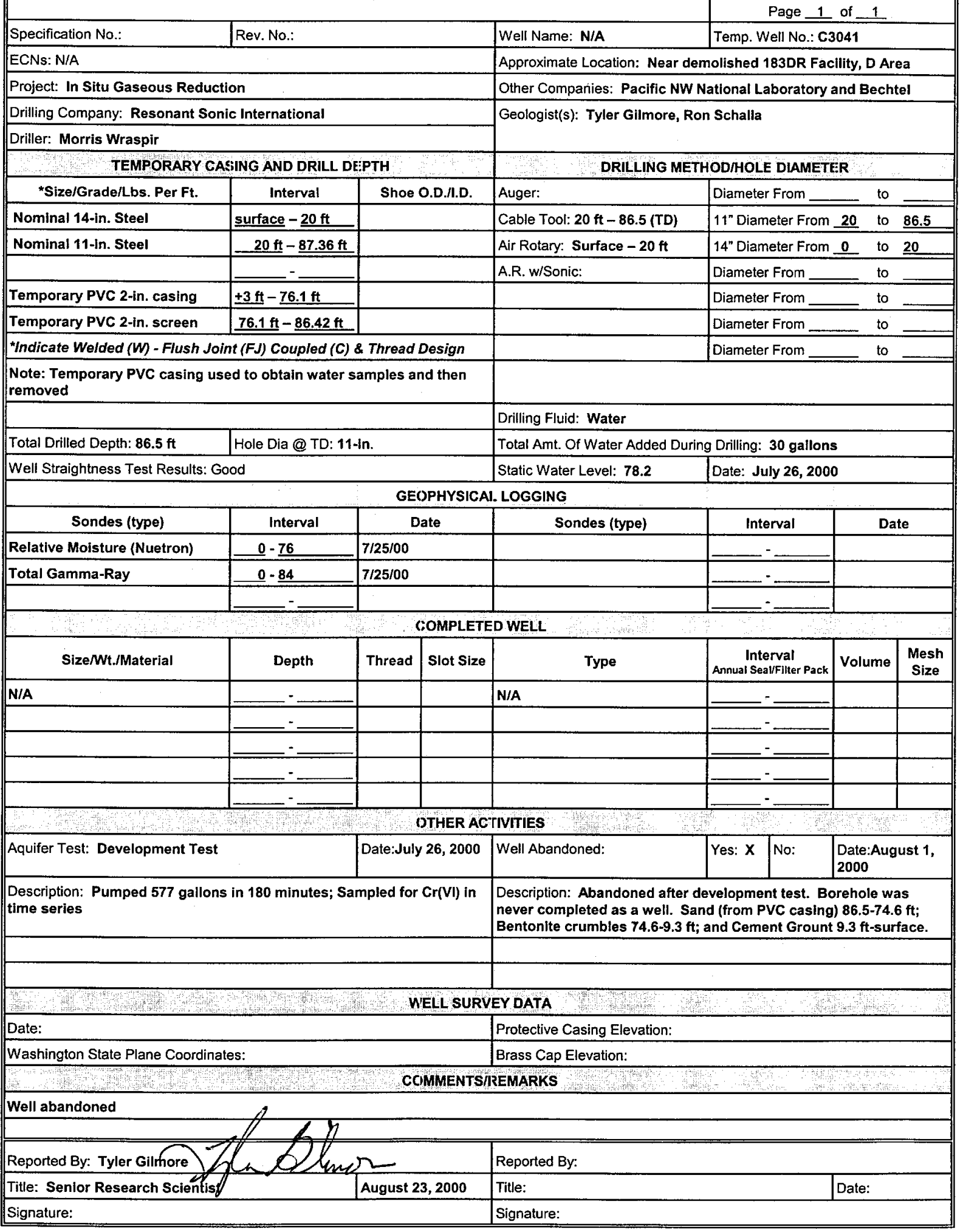




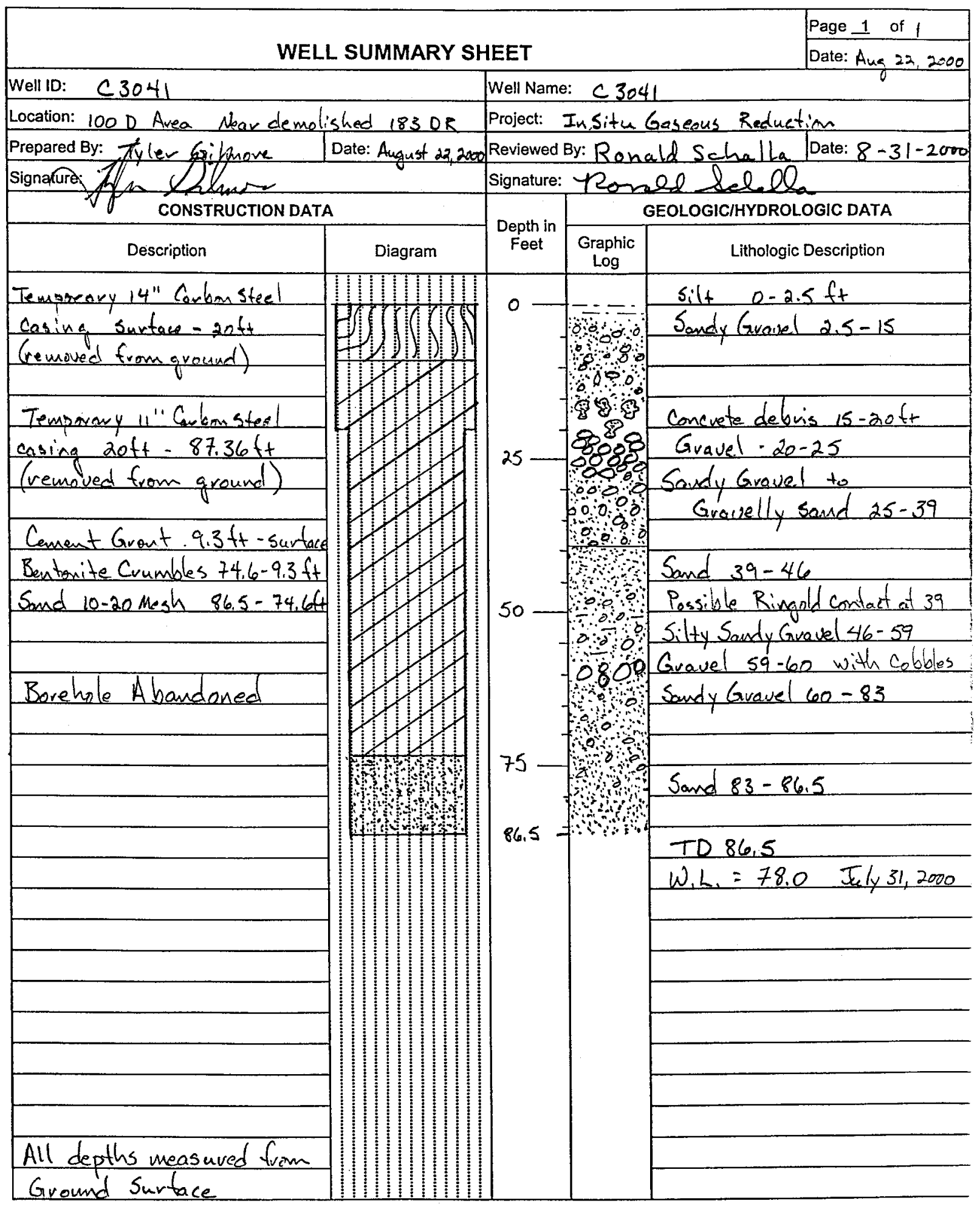




\begin{tabular}{|c|c|c|c|c|c|c|c|c|c|c|c|}
\hline \multicolumn{3}{|c|}{$\begin{array}{l}\text { Pacific Northwest } \\
\text { National Laboratory }\end{array}$} & \multicolumn{5}{|c|}{$\begin{array}{l}\text { DAILY } \\
\text { BOREHOLE LOG }\end{array}$} & 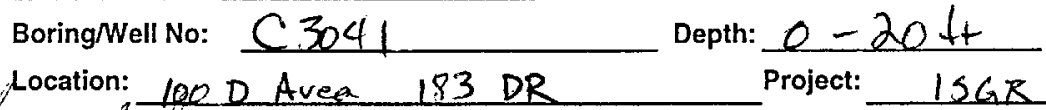 & \multicolumn{3}{|c|}{ Depth: $\frac{0-20 \mathrm{ft}_{t}}{\text { Project: } 15 \mathrm{GR}}$ Sheet 1 of 178} \\
\hline \multicolumn{4}{|c|}{$\begin{array}{l}\text { Logged by Ty6r Giln } \\
\text { Reviewed by Ronald } \\
\text { Lithologic Class. Scheme } \\
\text { Steel Tape/E-Tape }\end{array}$} & So & tind & $\overbrace{0}$ & The & Procedure & $\frac{200}{31-200}$ & \multirow{2}{*}{\multicolumn{2}{|c|}{$\begin{array}{l}\text { Drilling Contractor Resonant Sonic } \\
\text { Driller Kelly Cowden } \\
\text { Rig/Method Dresser XT 70E Aiv Rotary } \\
\text { Depth Control Point Comondseurface }\end{array}$}} \\
\hline & & & SAMPLES & CONTA & AMINATION & & & & & & \\
\hline DEPTH & TIME & TPPE & ID NUMBER & INSTR. & READING & MURE- & GOG & $\begin{array}{l}\text { (particle size distributlon, sorting, mineralogy, } \\
\text { roundness, color, reaction to } \mathrm{HCl} \text {, etc.) }\end{array}$ & $\begin{array}{l}\text { WATER } \\
\text { ADDED }\end{array}$ & CASING & $\begin{array}{l}\text { DRRLLING coMMENS } \\
\text { (driling rate, down time, blow counts, } \\
\text { water level, drill fluld, etc.) }\end{array}$ \\
\hline & $060 \mathrm{eg}$ & & & & & & & Drill location is at bonehde $2 b$ & & & Rig over dvill location; preparing to \\
\hline & & & & & & & & West of paved road horated near & & & divill \\
\hline & & & & & & & & turn in pipin enterine 183DR & & & \\
\hline & b84to & & & & & & & & & $10^{\prime}$ & Dilling \\
\hline & 2940 & & & & & & & About $10 f+$ - Righead jumping & & & water added to clyclon \\
\hline & & & & & & & & upand doun litue it is in collo & & $c^{\prime}$ & Add casing 10' \\
\hline & & & & & & & & and Goubters. Sonne water acted & & & \\
\hline & & & & & & & & to cyclone to kunck dust koum & & & \\
\hline & & & & & & & & Samples are brown in alor no & & & \\
\hline 10 & & & & & & & & concuete or debris hit so bur & & & \\
\hline & 1120 & Soil & c3041-10 & & & & & $10^{\prime}$ Groundup sed buant burown & & & drien sedinent then preusiors \\
\hline & & & & & & & & Sample 11:18 Ran Aach kittor $C_{2}{ }^{+6}$ & & & less water added 1 \\
\hline 15 & 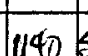 & $\left.S_{n}\right)$ & $(3,41-6)$ & & & & & and had a $0.01 \mathrm{mg} / \mathrm{L}$ result; no visible punted & & & \\
\hline & & & $C 3,41-15$ & & & & & $15^{\prime}$ Ground sedidanent clasts to & & & Hand spot at 12' durller \\
\hline & & & & & & & & 1 cem that are whole; green & & & thutes it might be corcuete \\
\hline & & & & & & & & tiat, conld be sime concrete & & & 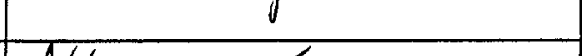 \\
\hline 20 & 1410 & Soill r a r a r a r a & $c_{2}^{2}+1-9 n$ & & & & & Stample 11:25 & & 5 & Add casing $5^{\prime}$ \\
\hline & & & & & & & & Coment - no cobbles green color & & & \\
\hline & & & & & & & & When wet - concuete gray when duy & & & \\
\hline & & & & & & & & five qrained & & & \\
\hline & & & & & & & & Will tear down Ratroce Ria and & & $-5^{\prime}$ & Take $5^{\prime}$ iff \\
\hline & & & & & & & & mane cabletorl on & & & Starter casing \\
\hline & & & & & & & & & & & \\
\hline
\end{tabular}




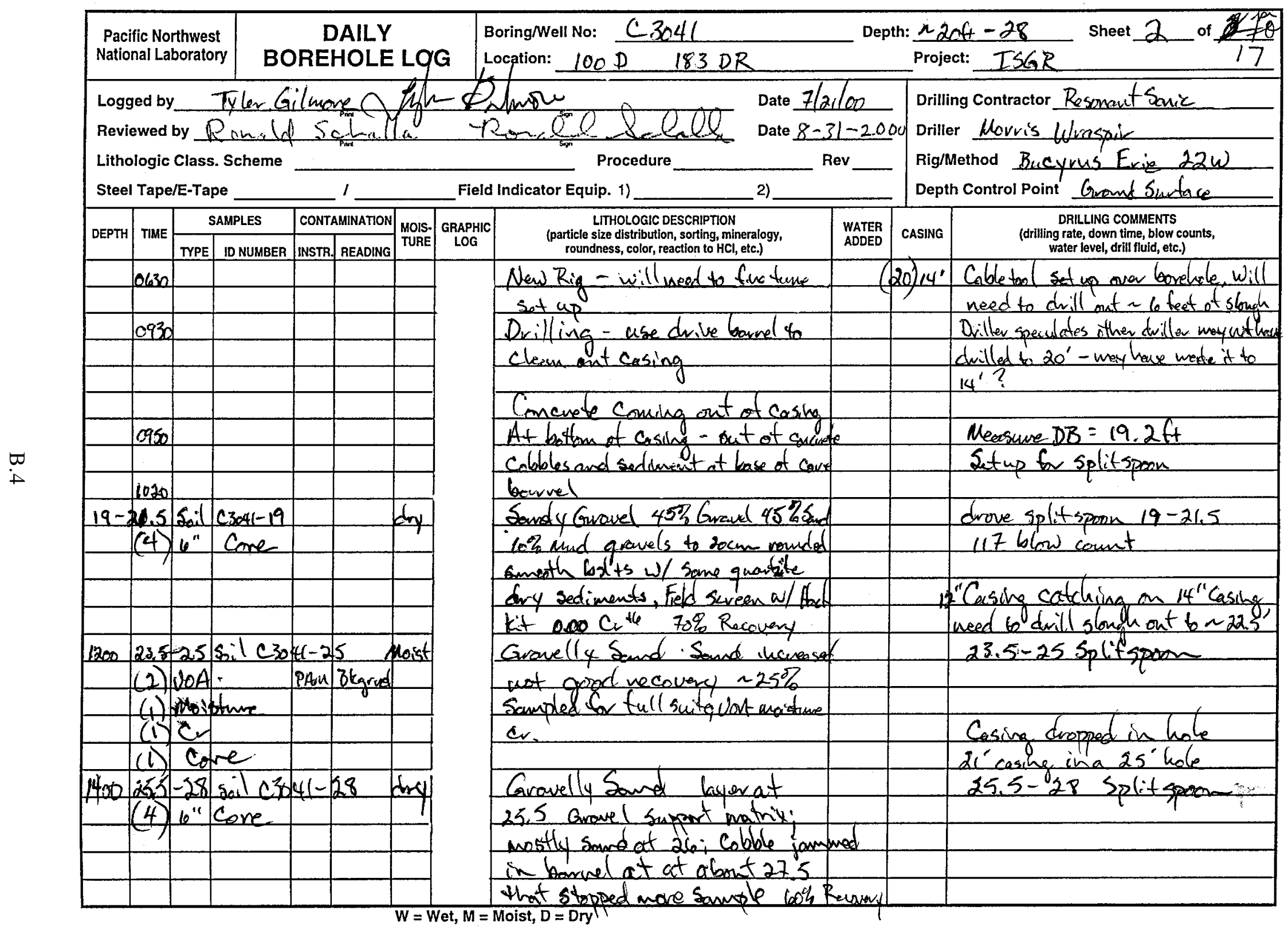




\begin{tabular}{|c|c|c|c|c|c|c|c|c|c|c|}
\hline \multicolumn{3}{|c|}{$\begin{array}{l}\text { Pacific Northwest } \\
\text { National Laboratory }\end{array}$} & \multicolumn{4}{|c|}{$\begin{array}{c}\text { DAILY } \\
\text { BOREHOLE LOG }\end{array}$} & 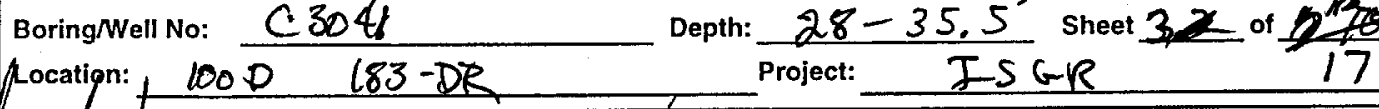 & \multicolumn{3}{|c|}{ Depth: $\frac{28-35.5^{\prime}}{\text { Project: }}$ IS GReet $3 \geq$ of $\frac{17}{17}$} \\
\hline \multicolumn{9}{|c|}{ 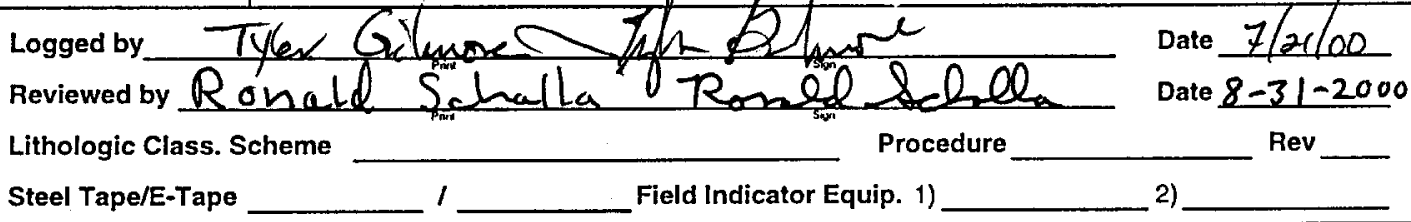 } & \multicolumn{2}{|c|}{ 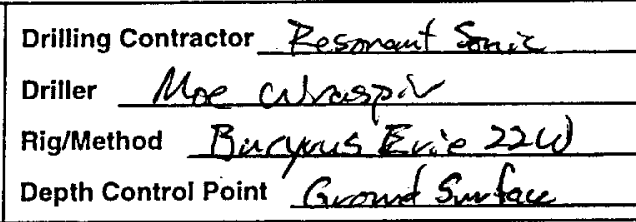 } \\
\hline DEPTH & TME & SAM & LES & 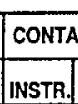 & Mination & \begin{tabular}{l|l} 
MOIS- GRAPH \\
TURE \\
LOG
\end{tabular} & 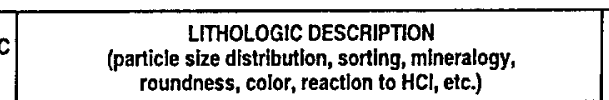 & $\begin{array}{l}\text { WATER } \\
\text { ADDED }\end{array}$ & CASING & 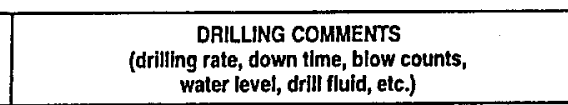 \\
\hline n430 & & 0.58 & $c 3_{0}$ & & & Dry & Sandy Grouvel lange Clasts & & & $28-30.5$ split spoosen \\
\hline & $(2)$ & & & & & & very lose likely matrix & & & (no $\left.6^{\prime \prime}\right)$ (2 lexcan loners lest \\
\hline & & & & & & & Supported Gravel $70 \%$ Reeweny & & & \\
\hline 1500 & 30 & -33 & silc & 304 & & Dos & Grovelly Sand & & & $30.5-33$ Sol.tspoon \\
\hline & (2) & $12 \%$ & & & & & As one $60 \%$ Reevery & & & \\
\hline 1553 & $33-$ & 55 & 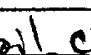 & 3024 & & & drilled tiahter. More & & $10.0 \mathrm{l}$ & $\begin{array}{l}\text { Add cabiva } \\
33-35,5 \text { Solitspoer }\end{array}$ \\
\hline & & & (16) & & & 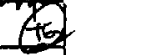 & moist 1 oood recal & thent & & \\
\hline & (4) & 6 a) 5 & Ne & & & & $80 \%$ & & & \\
\hline $163 n$ & & & & & & & & & & \\
\hline & & & & & & & & & & Endot Day \\
\hline & & & & & & & & & & \\
\hline & & & & & & & & & & \\
\hline & & & & & & & & & & \\
\hline & & & & & & & & & & \\
\hline & & & & & & & & & & \\
\hline & & & & & & & & & & \\
\hline & & & & & & & & & & \\
\hline & & & & & & & & & & \\
\hline & & & & & & & & & & \\
\hline & & & & & & & & & & \\
\hline
\end{tabular}




\begin{tabular}{|c|c|c|c|c|c|c|c|c|c|c|c|}
\hline \multicolumn{3}{|c|}{$\begin{array}{l}\text { Pacific Northwest } \\
\text { National Laboratory }\end{array}$} & \multicolumn{4}{|c|}{$\begin{array}{c}\text { DAILY } \\
\text { BOREHOLE LOG }\end{array}$} & & \multirow{2}{*}{\multicolumn{2}{|c|}{ 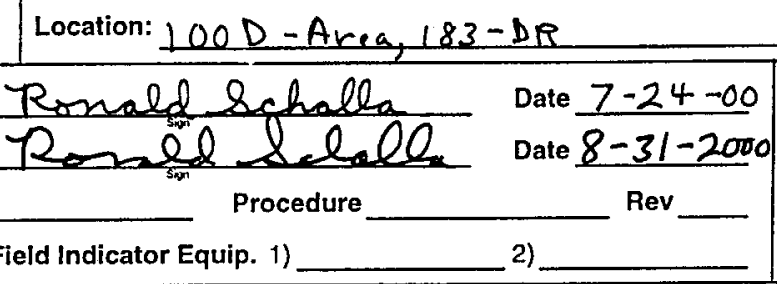 }} & & \\
\hline \multicolumn{4}{|c|}{$\begin{array}{l}\text { Logged by Ronald } \\
\text { Reviewed by Ronald } \\
\text { Lithologic Class. Scheme } \\
\text { Steel Tape/E-Tape }\end{array}$} & $\frac{L S}{S}$ & $\begin{array}{l}\text { chal } \\
\text { 2och } \\
\text { sectsc } \\
1\end{array}$ & $\frac{\mathrm{la}}{\mathrm{ll}}$ & $\begin{array}{l}\text { Ronald ichalla } \\
\text { Romald \& lall }\end{array}$ & & & \multicolumn{2}{|c|}{$\begin{array}{l}\text { Drilling ContractorResonant Sonic Int } \\
\text { Driller Morris "Moe" Wraspir } \\
\text { Rig/Method Bucyrus Erie } 22 \mathrm{~W} \\
\text { Depth Control Point Ground Surtace }\end{array}$} \\
\hline $\begin{array}{l}\text { DEPTH } \\
\mathrm{Ht}\end{array}$ & TME & TYPE & SAMPLES & CONT/ & $\begin{array}{l}\text { AMINATION } \\
\text { READING }\end{array}$ & MOIS- & $\begin{array}{l}\text { GRAPHIC } \\
\text { LOG }\end{array}$ & $\begin{array}{c}\text { LITHOLOGIC DESCRIPTION } \\
\text { (particle size distrtrbuttion, sorting, mineralogy, } \\
\text { roundness, color, reaction to } \mathrm{HCl} \text {, etc.) }\end{array}$ & $\begin{array}{l}\text { WATER } \\
\text { ADDED }\end{array}$ & CASING & $\begin{array}{c}\text { DRILLING COMMENTS } \\
\text { (drilling rate, down time, blow counts, } \\
\text { water level, drll fluld, ete.). }\end{array}$ \\
\hline 35.5 & 0740 & Spoous & $6304-365$ & $G M$ & & S1: & $\because \because \because$ & Gravelly SAND (sw) sand is & None: & $\begin{array}{l}11.75^{4} \\
0.0^{4}\end{array}$ & Sampled from 35.5 to $38^{\prime}$ \\
\hline 96,5 & 11 & $12^{\prime \prime} 6$ & 更. & & & & & $30 \%$ ves $-c 5,50 \%$ med 20 tututun & & 10.254 & recovered only $80^{\circ} 4$ overall, \\
\hline 37.5 & $"$ & long is & $(3041-375$ & & & & & trace amounts of silt, slighty & & IQ & butech 12 "10ug tube $95 \%$ \\
\hline 37.5 & $"$ & Nol & & fr. & & & $\because \because \because$ & moit, dark gray $(10 Y R-4 / 1)$ & & & foll. \\
\hline 38.0. & $"$ & of 5 & Sampler & belo & w bask & sot & & Gravel $80 \%$ fine, $20 \%$ med. & & & \\
\hline & & & & & & & & - Baralt tyuntz nocementatio & & & \\
\hline 38.0 & 0835 & Splitir & C $3041-39$ & & & & & & & & \\
\hline 39.0 & $n$ & Spoom & & & & & $\because \because 0$ & & & & \\
\hline $39.0-$ & " & I. & $C 3041.40$ & & & mosist. & & SAND (SP $\Rightarrow 98 \%, 2 \%$ silt & & & Sampled from $38.0-40.5^{\prime}$ \\
\hline 40. & " & $\therefore$ & & & & & & orless, $0 \%$ gravel to traces of & & & Nearly $100 \%$ recovery 38 to 40. \\
\hline 40.5 & No & irsed & very 40 & -4 & $6 . \Sigma^{\prime}$ & & & fine tovery tine gravel Less & & & No recovery from $40-40.5^{-1}$ bocart \\
\hline 40.5 & 0930 & Spliti & & & & & & than $5 \%$ vas. - cs sand, & & & be low basket, \\
\hline 41.5 & 1. & $\begin{array}{ll}\text { spoon } \\
12^{21}\end{array}$ & $\frac{}{63041-41,5}$ & & & S!. & & $80 \%$ madium, $15 \%$ finctovfu. & & & Sampled from $40.5^{\prime}-43^{\prime}$ \\
\hline $41,5-$ & 1 & $\frac{12}{10 n}$ & & 2 vo & Avial & Moist & & Busult puartz sand Dark & & & $95 \%$ recovery from 40.5 tryes \\
\hline 42.5 & !. & & & ton & $=\operatorname{mon}(i)$ & tro & & gray $(10 Y R-4 / 1)$ & & & No Recoveryf from 42.5 to $43.0^{\prime}$ \\
\hline 42.5 & to 4 & 3.07 & $\frac{C 3041-42.5}{N_{0}} R_{e}$ & & & & & No C.ementation & & & 2 VOA vials fillod with me thenf \\
\hline & & & & $\operatorname{cov}$ & ery & & & & & & +5 gram of foil. Also, moisturetin. \\
\hline $43,0-$ & & & - & & & & & slightly more silt about & & & Sampled from $43^{\prime}-45.5^{\prime}$ \\
\hline 44.0 & 1000 & $\begin{array}{lll}\text { split } \\
\text { Spoum }\end{array}$ & $(3041-44$ & & & Si. & $\because \because$ & $2-3 \%$ then above & & & IS to $100 \%$ recovery in twolexan \\
\hline 44.0 & & " & & & & Moist & & & & & $12^{\prime \prime}, 4$ in dia tubre. No Recovery \\
\hline 45,0 & 1000 & $12^{\prime \prime}$ & C $304-45$ & & & & $\because \because$ & & & & from 45.0 to 45,5 (below buskot) \\
\hline 45,0 & -45 & $5 \mathrm{No}_{0}$ & Recover & & & & $\because \because$ & & & & \\
\hline beld & $w$ & bask & $\mathrm{ket}$ & & & & $\because \because$ & & $\downarrow$ & $Y$ & \\
\hline
\end{tabular}




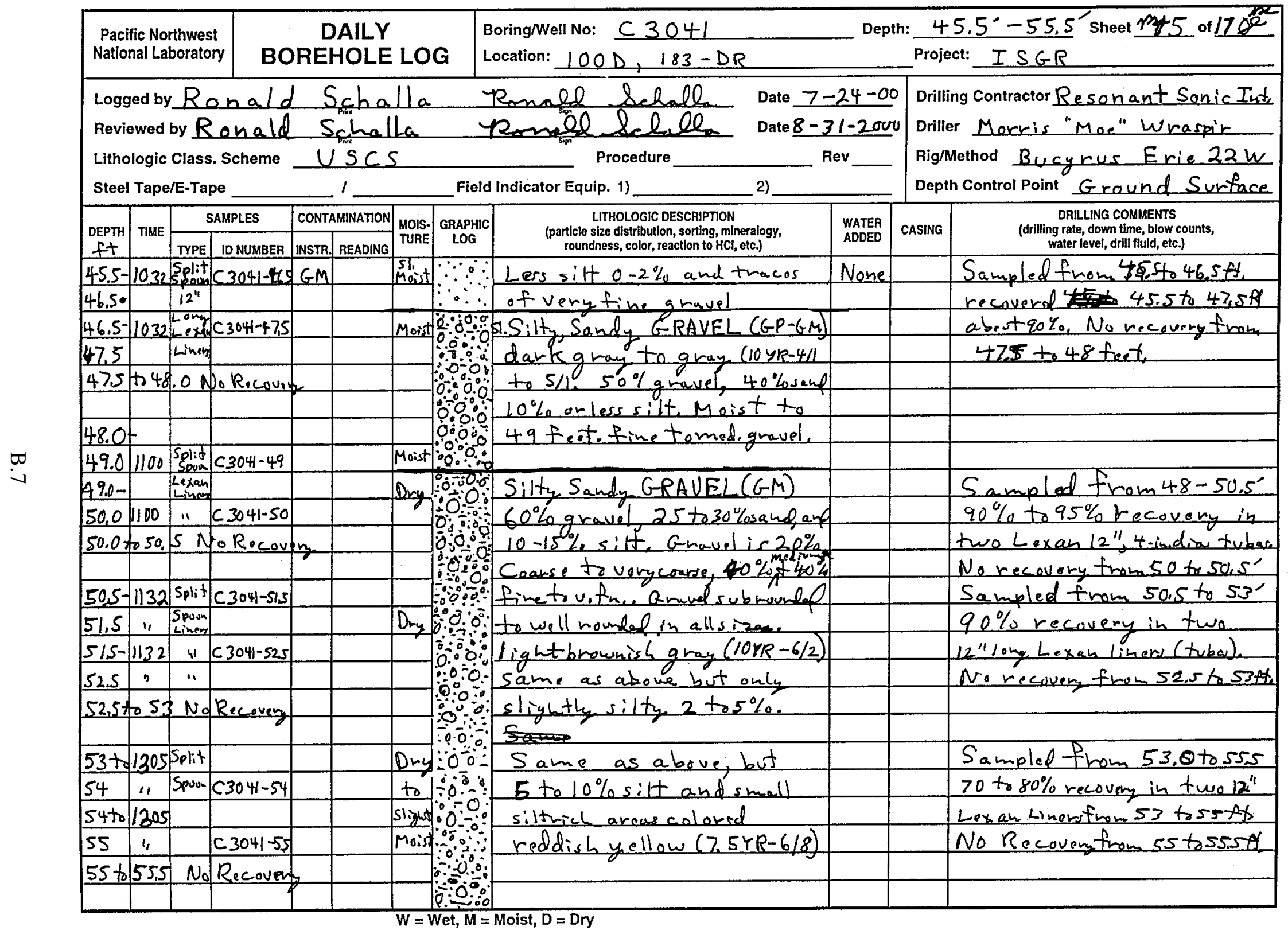




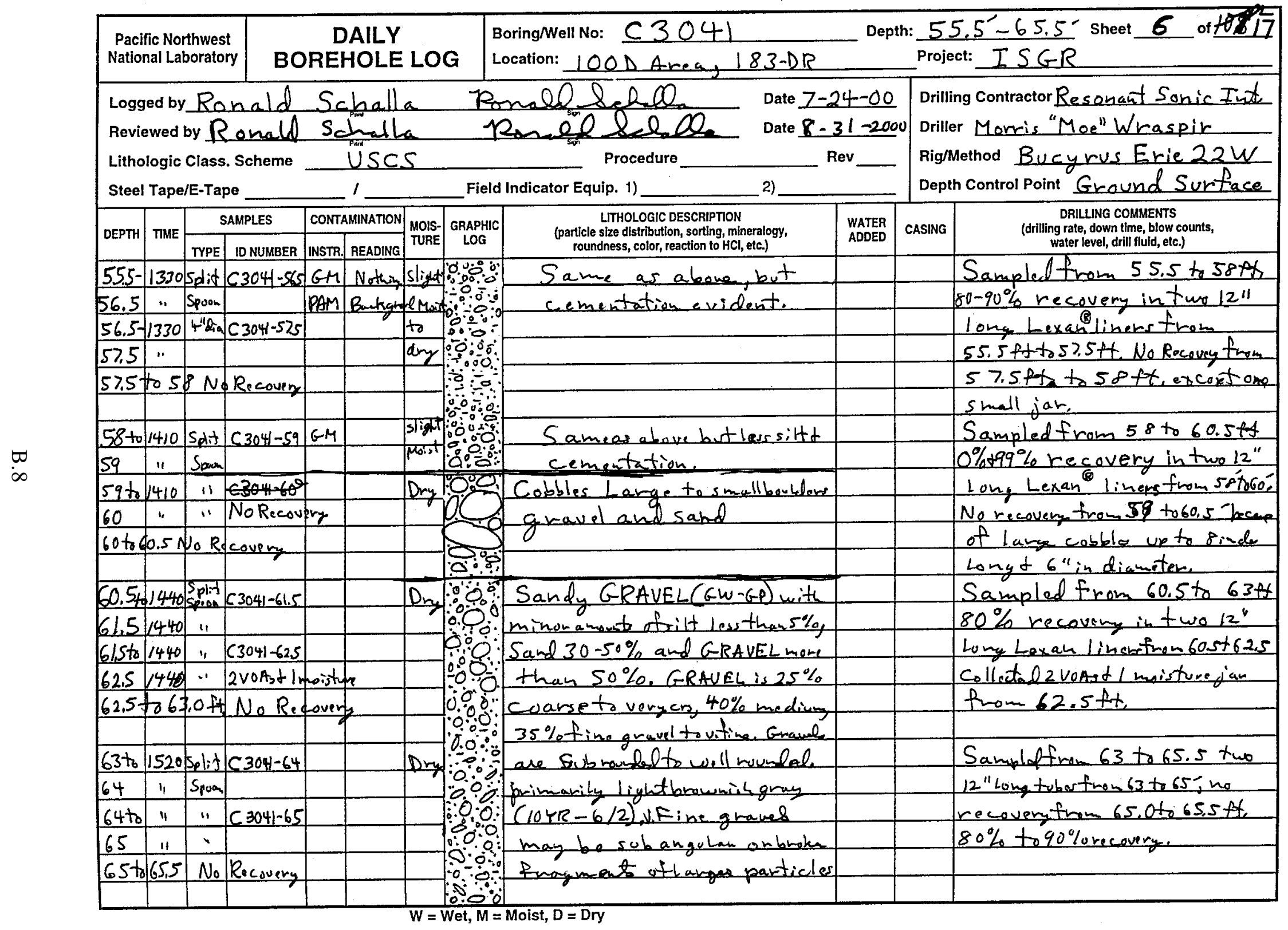




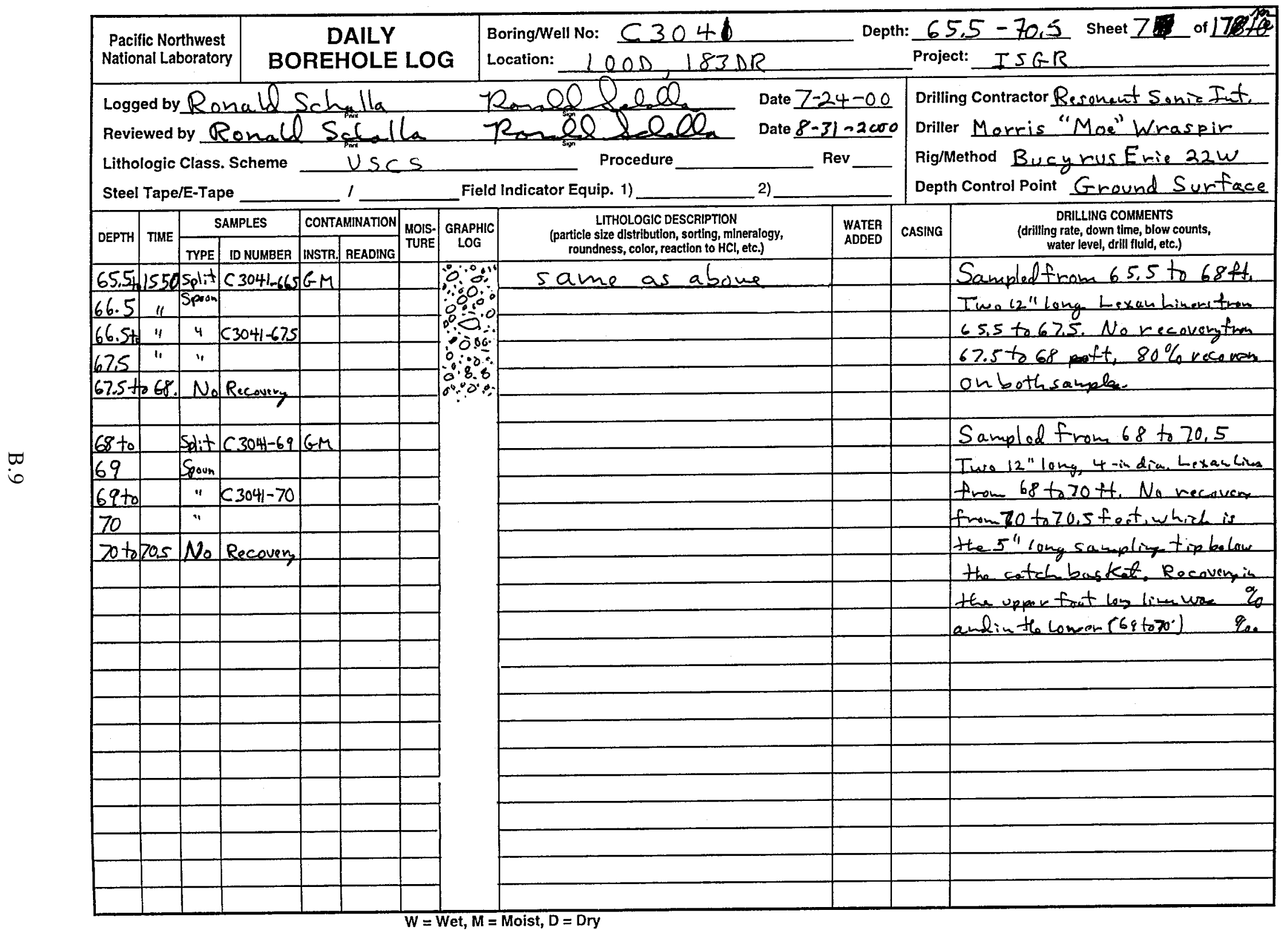




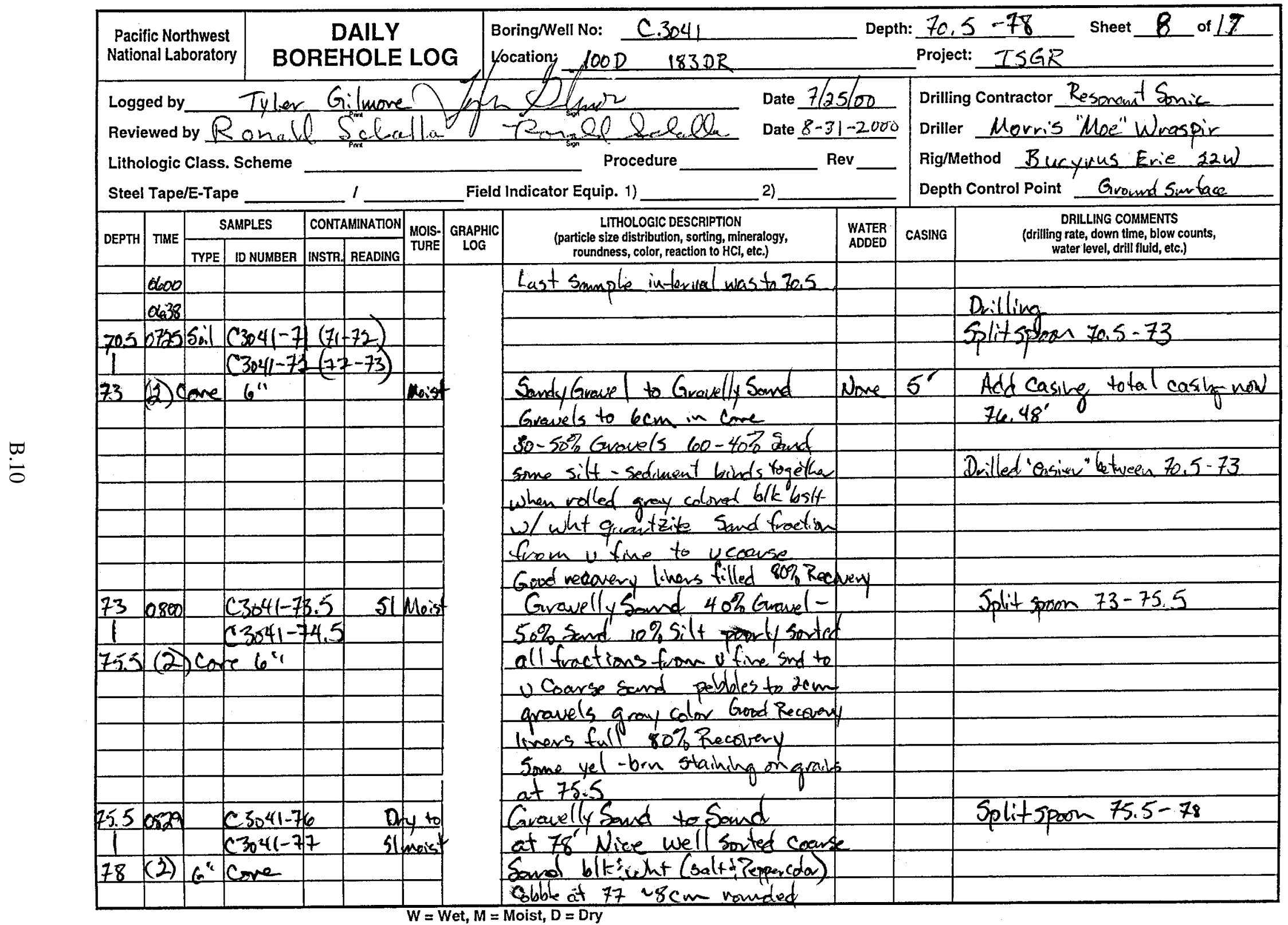




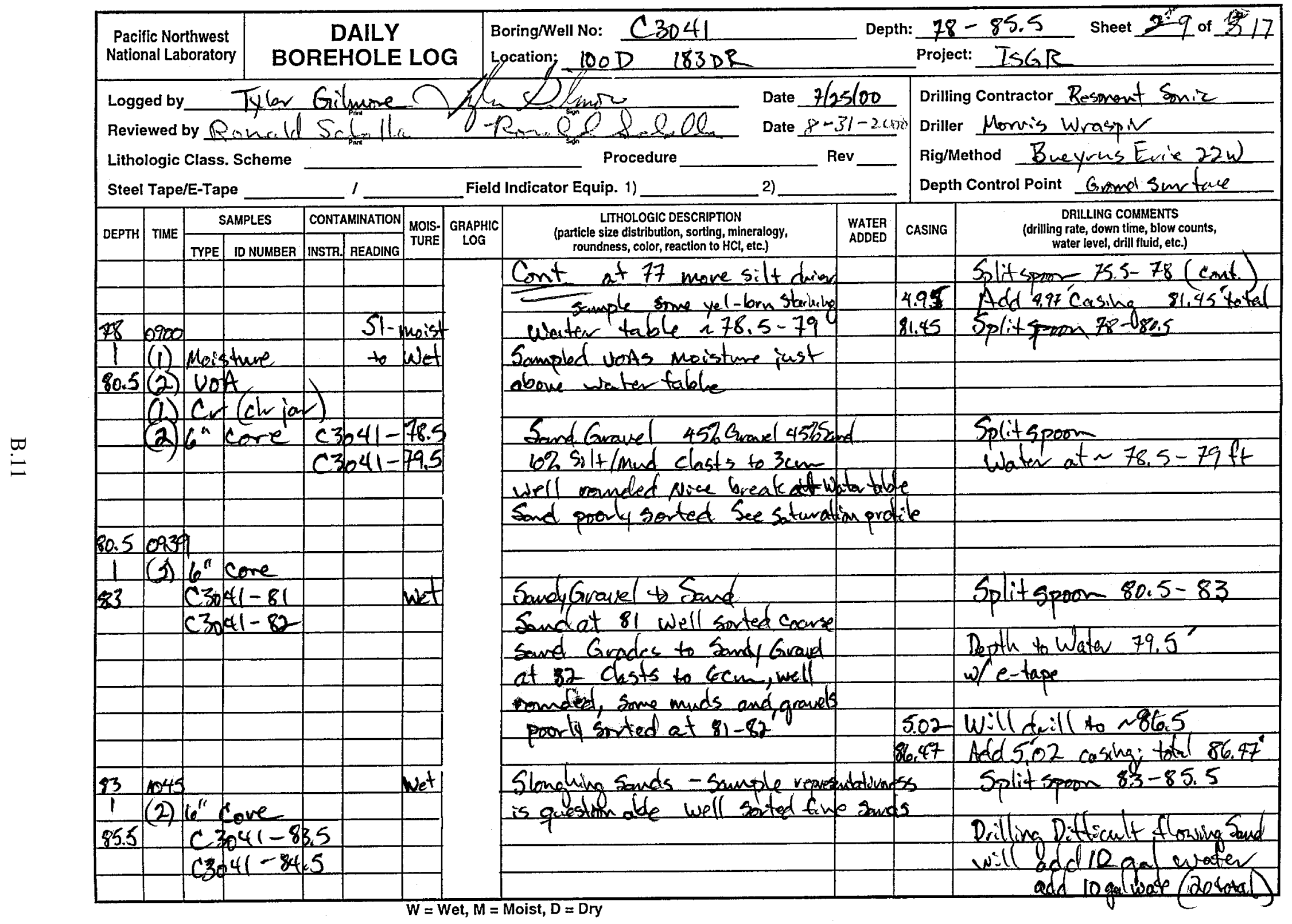




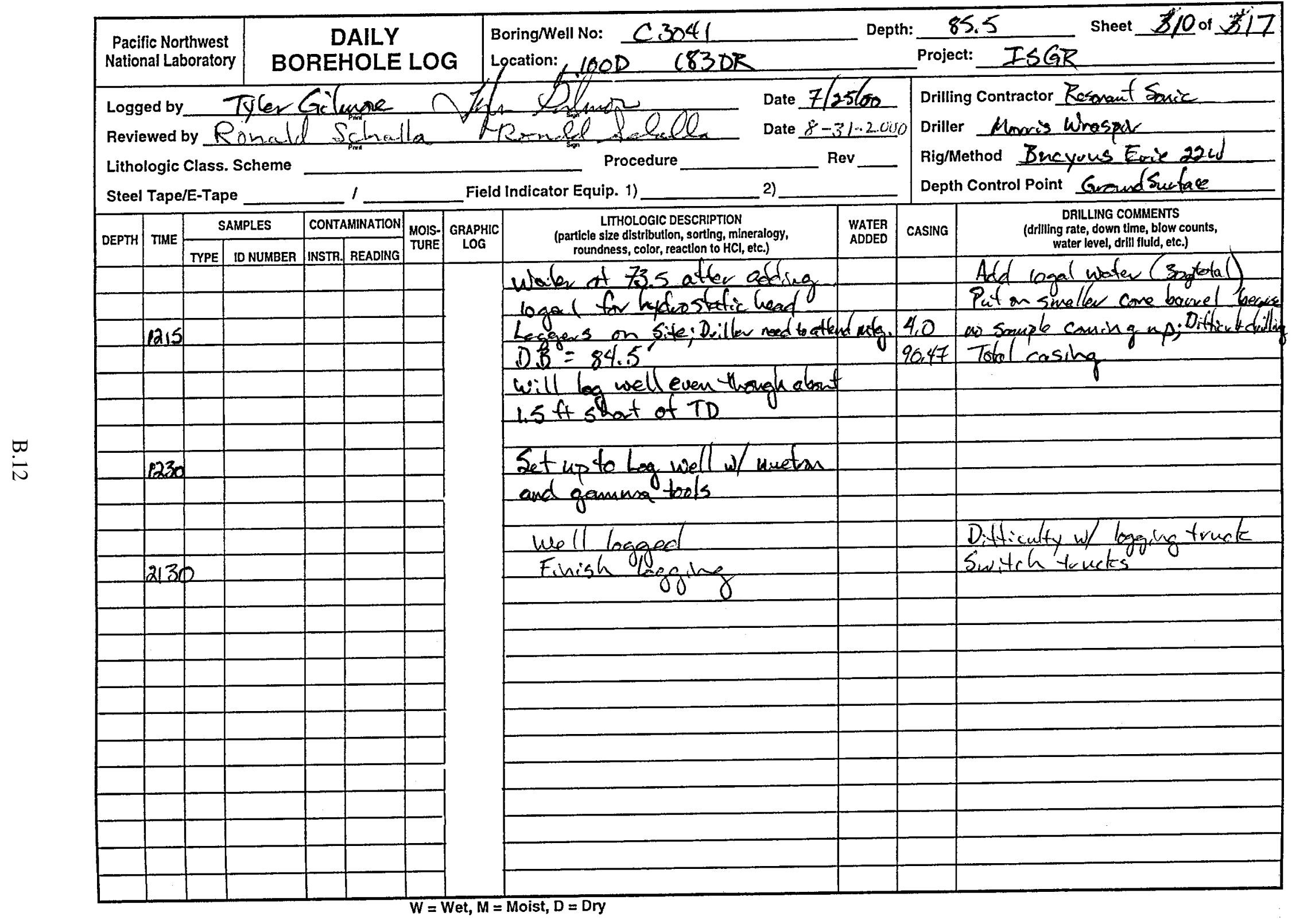




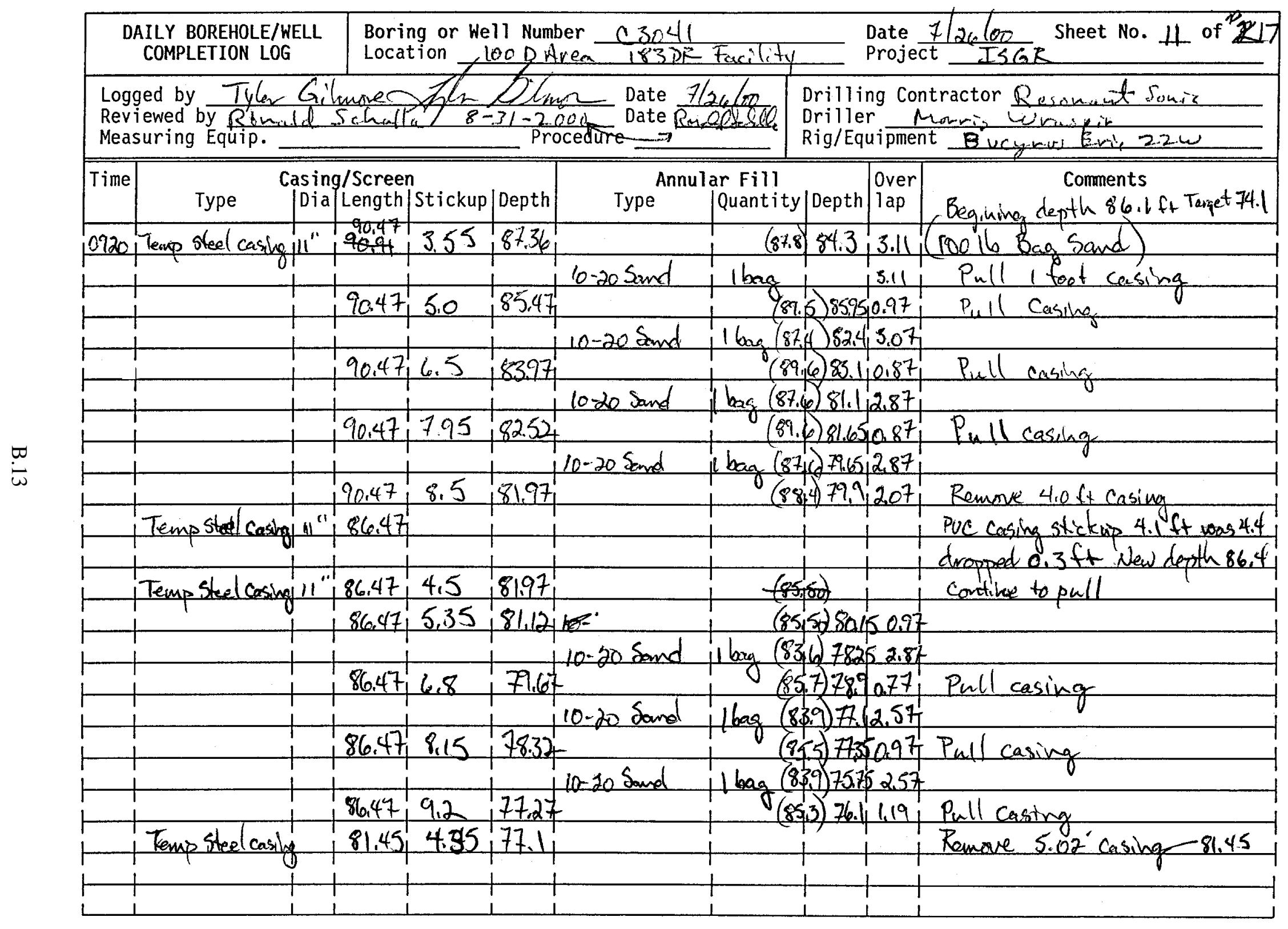




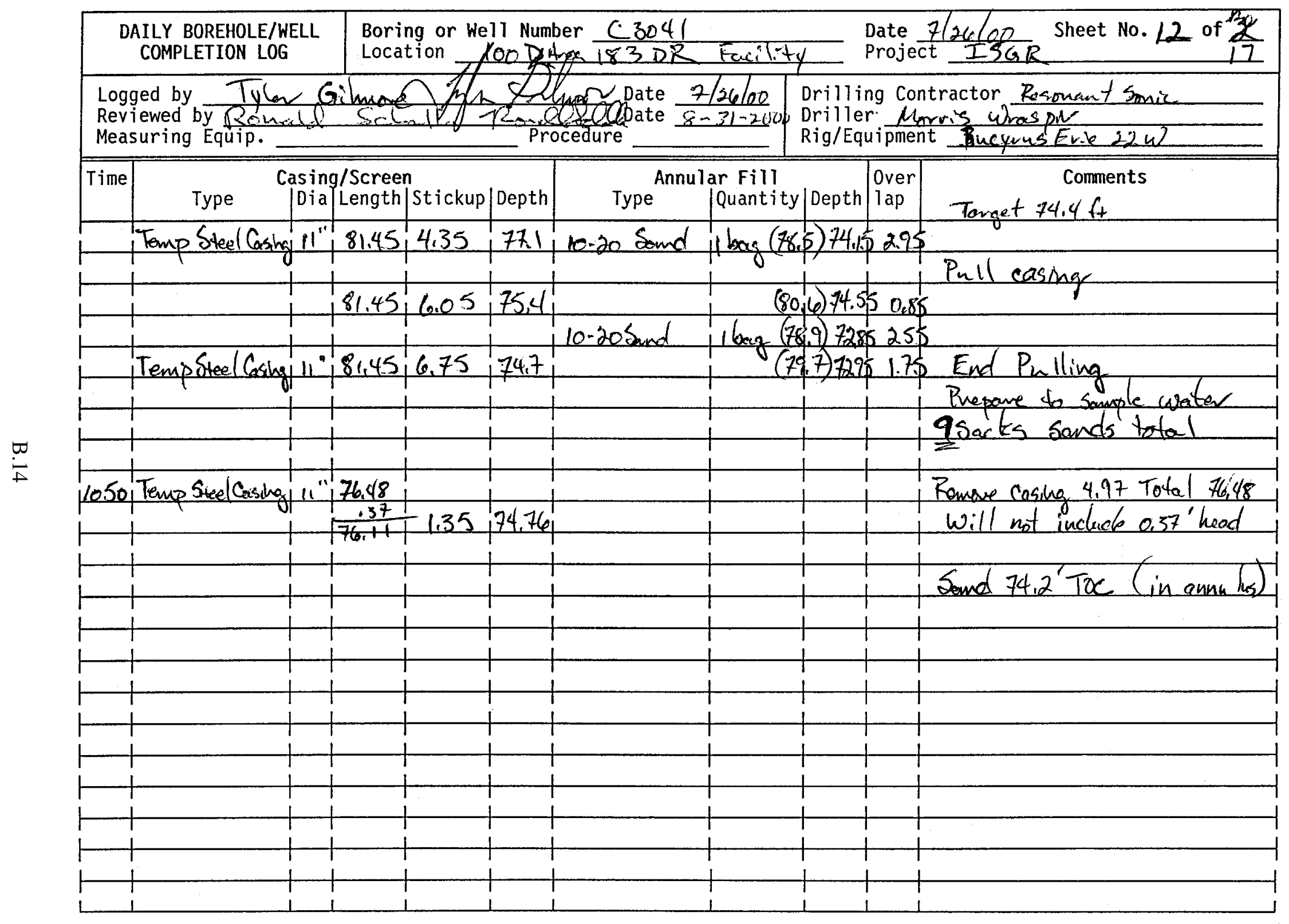




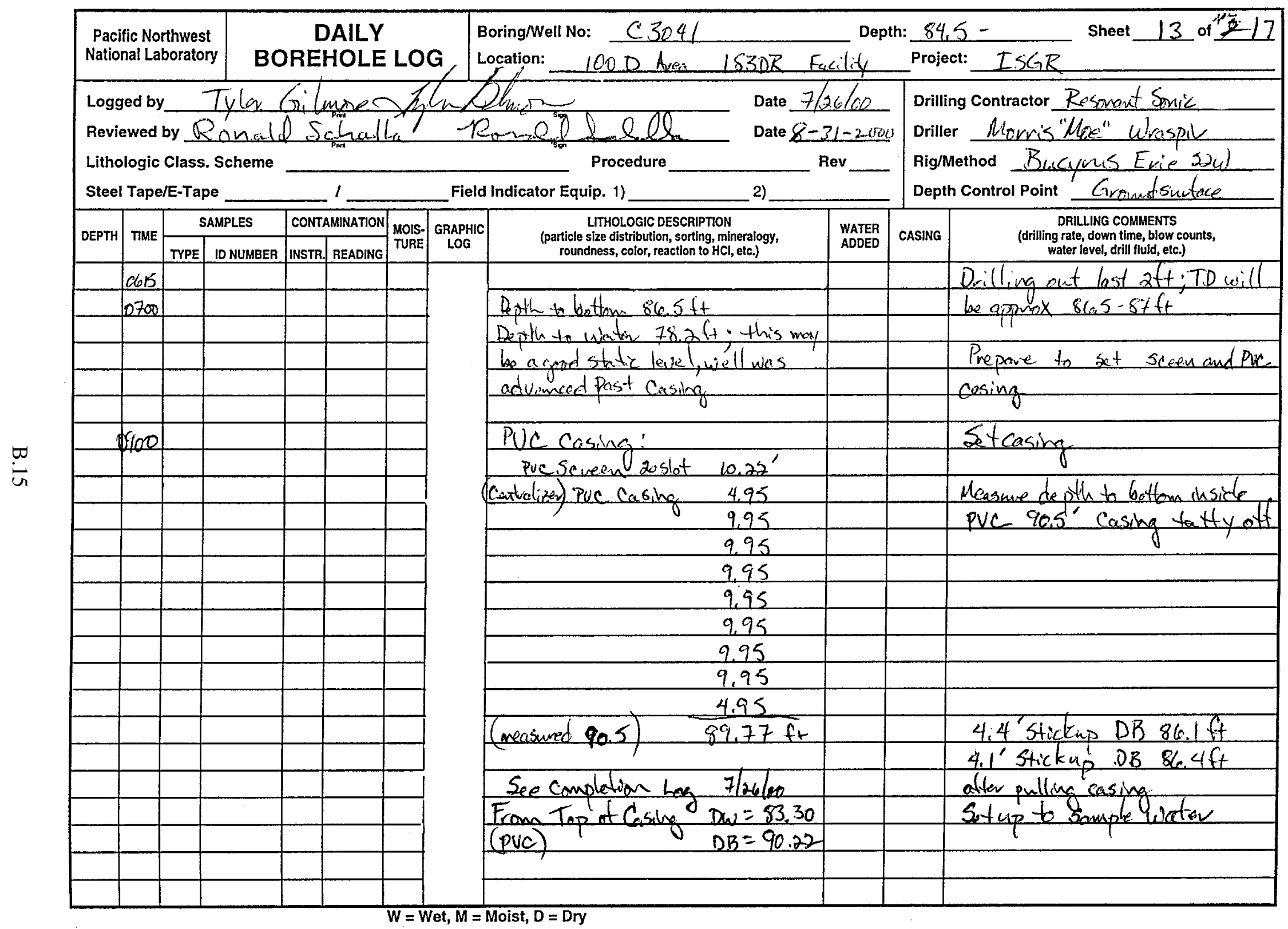




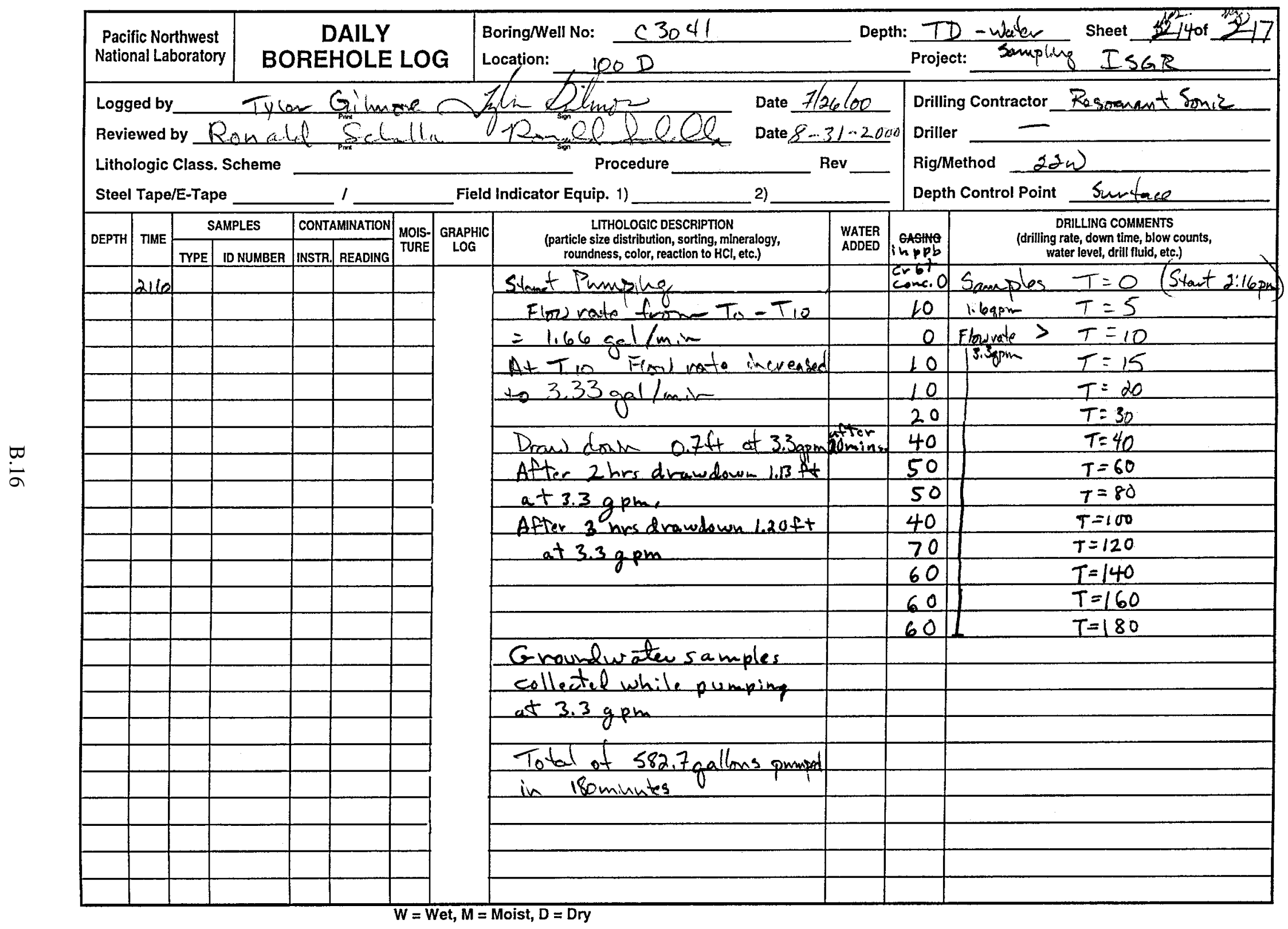




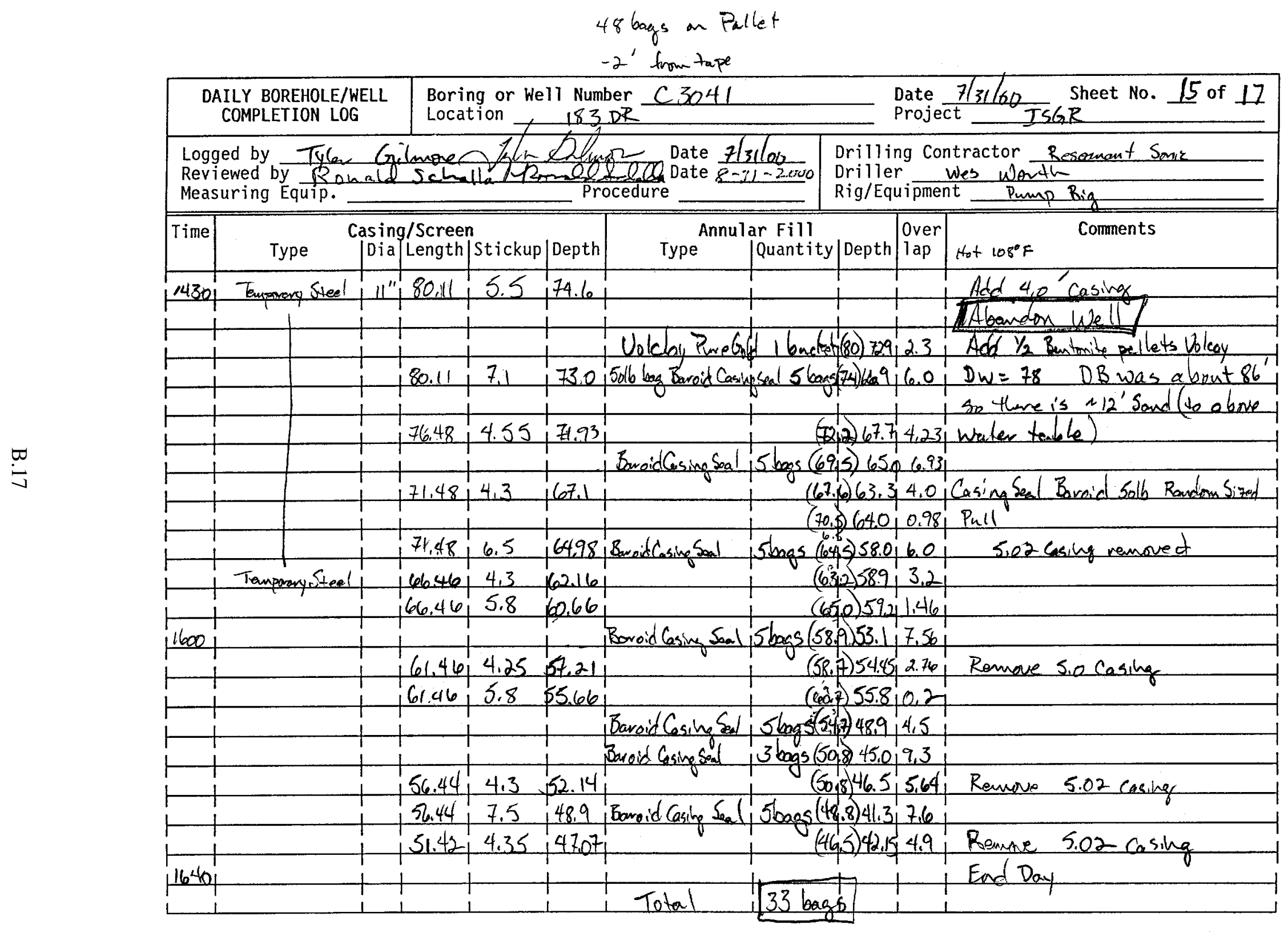




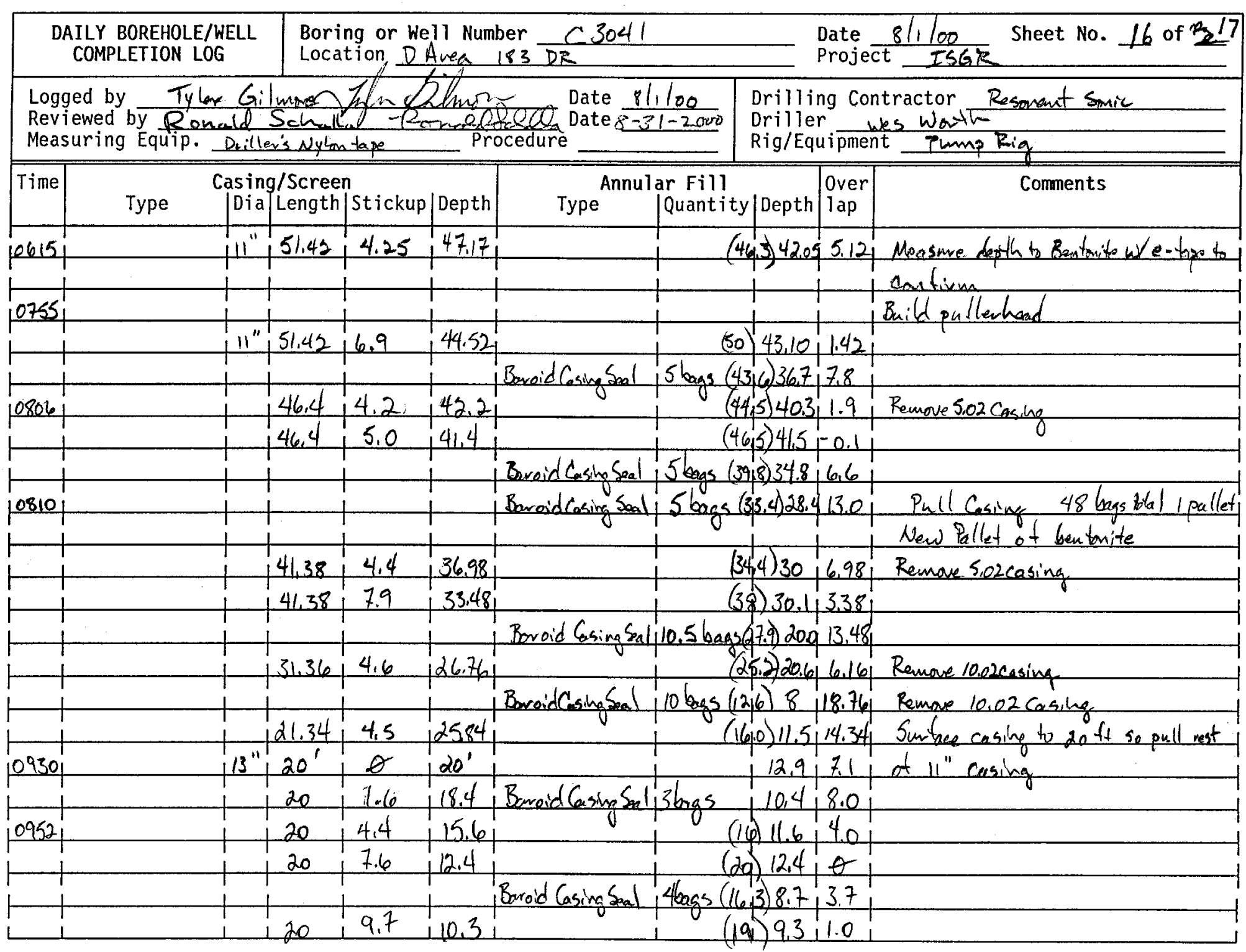




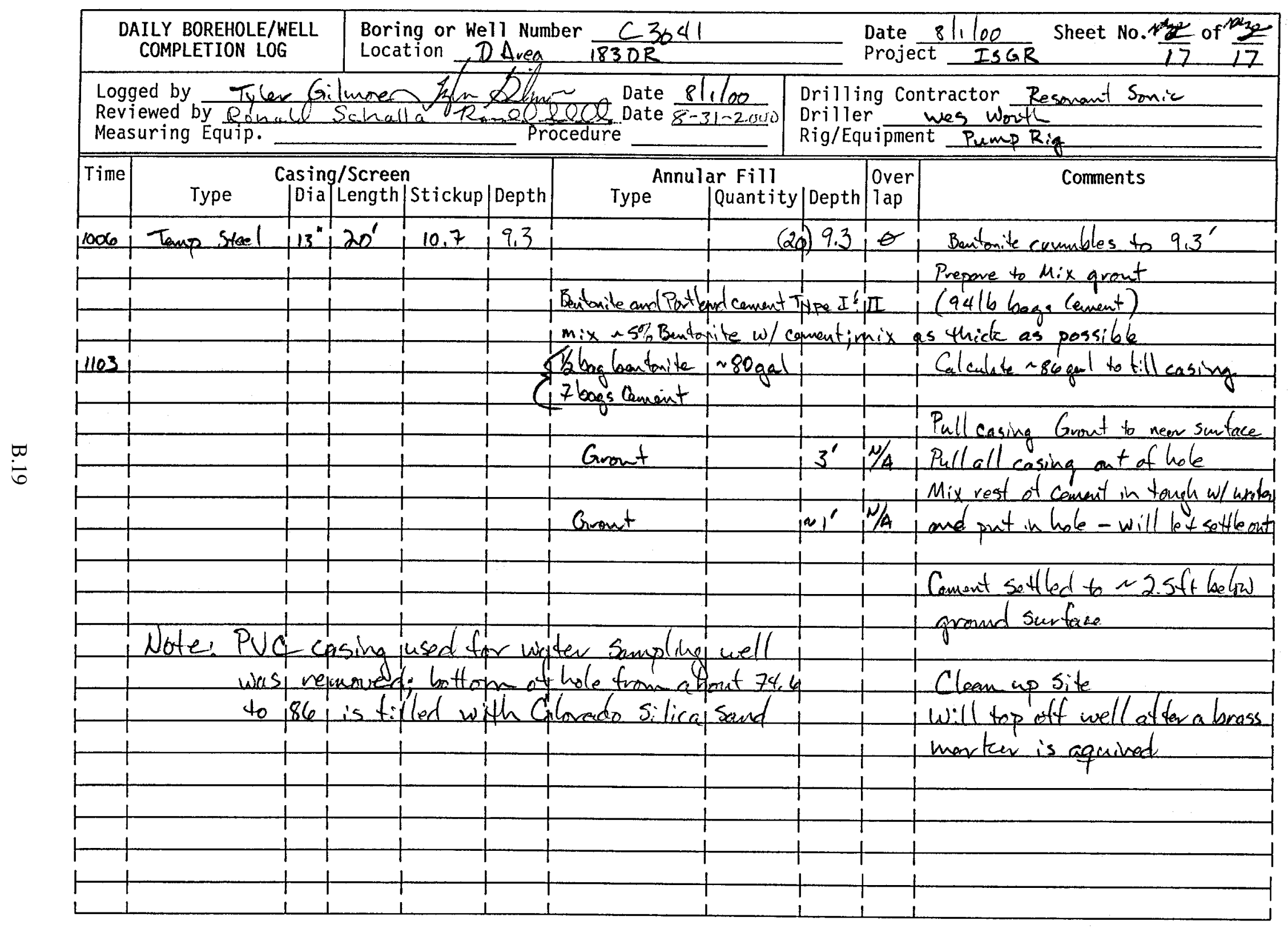




\section{RLS Total Gamma-Ray}

Waste Management Technical Services

Project: ISGR-183DR

Borehole: C-3041
Log Date: July 25, 2000

Depth Datum: Ground Level

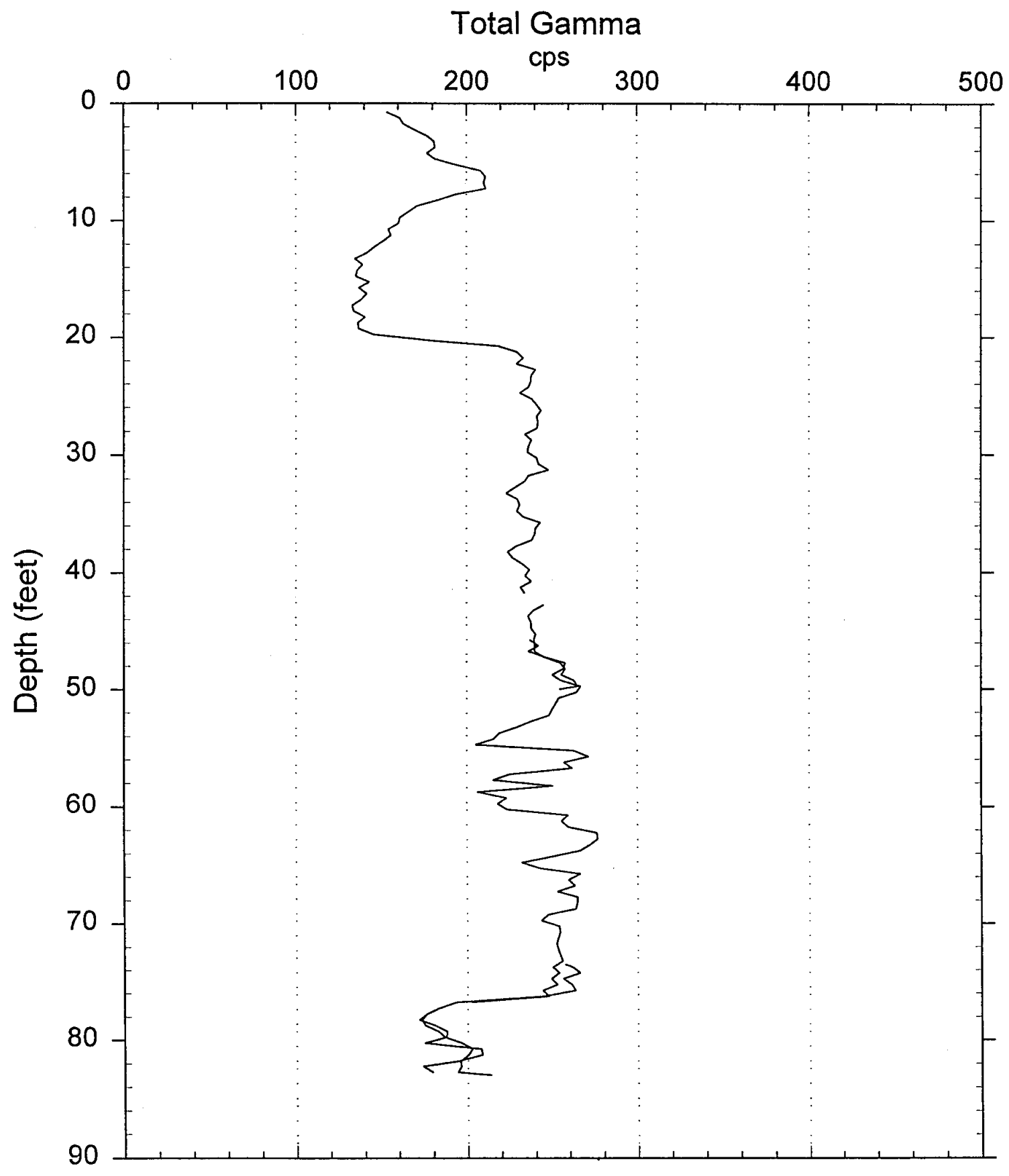

B. 20 


\section{RLS Relative Moisture}

Waste Management Technical Services

Project: ISGR-183DR

Borehole: C-3041

Log Date: July 25, 2000

Depth Datum: Ground Level

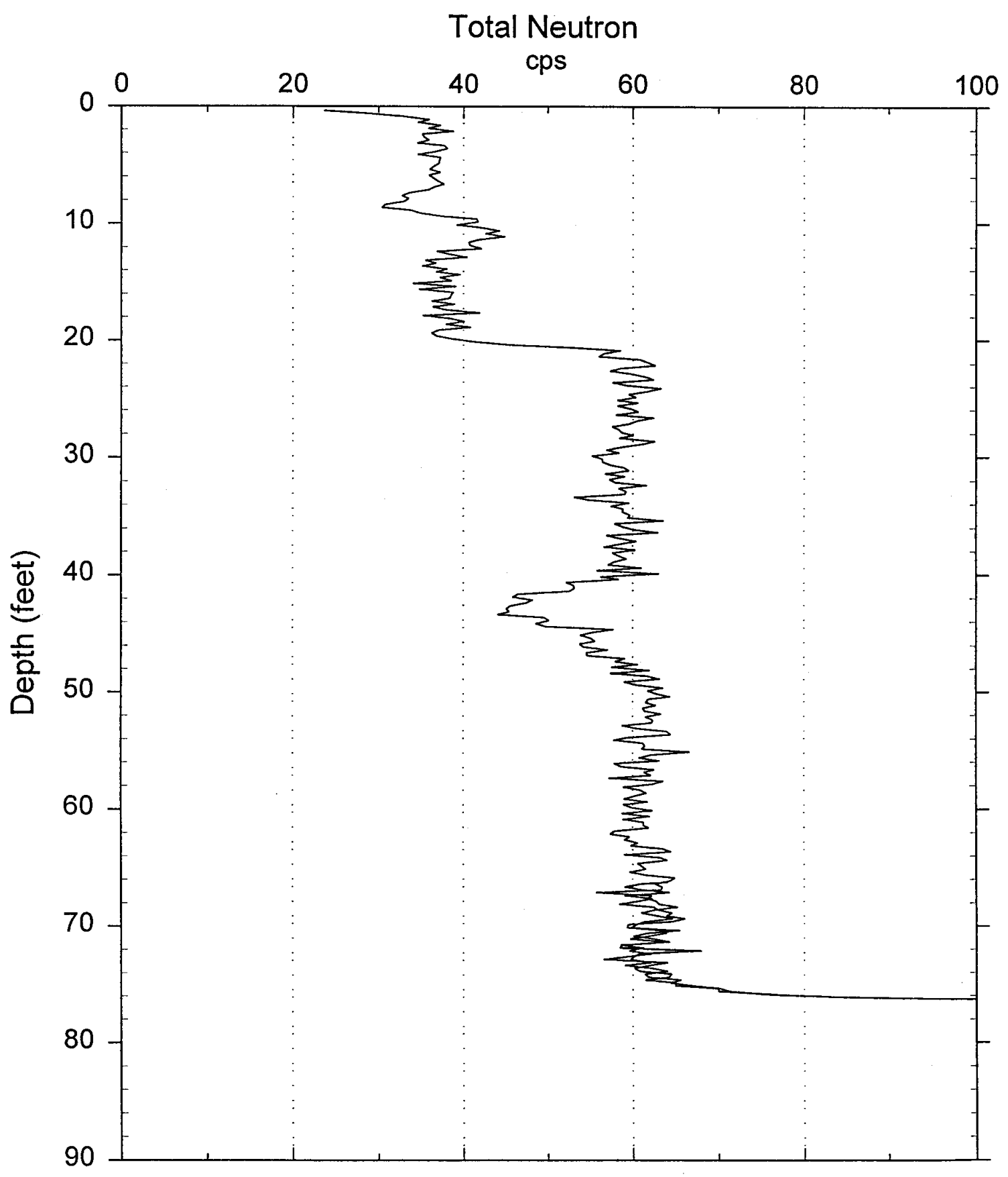

B.21 


\section{Appendix C}

Sediment and Groundwater Sampling and Analysis for 183-DR Boreholes C3040 and C3041 


\section{Appendix C}

\section{Sediment and Groundwater Sampling and Analysis for 183-DR Boreholes C3040 and C3041}

\section{C.1 Sample Collection}

Core Samples - Drilling of the characterization boreholes at the 183-DR site began on July 20, 2000. Drilling was initiated by air rotary, but sampling was conducted while drilling with a cable tool rig. Predrilling characterization was conducted at the $\mathrm{C} 3040$ borehole site previously (Thornton et al. 2000) to a depth of 20 feet below ground surface (bgs). Sampling during C3040 borehole installation was initiated at 20 feet bgs and continued to 5 feet below the water table. Sampling during C3041 borehole installation was initiated at 10 feet bgs and continued to 5 feet below the water table. All core samples were collected with a 2 feet by 4 inch diameter split spoon sampler equipped with either 6-inch or 12-inch long lexan liners and were collected ahead of the driven casing. Upon insertion of the split spoon sampler to its full length into the undisturbed subsurface sediment sampling interval, the sampler was removed from the borehole and opened. The lexan liners were transferred to a worktable and screened with a portable beta/gamma meter. If a sediment volatile organic sample was to be collected from a specific coresegment, the 1 to 5 gram sample was collected immediately from the core with a stainless steel spatula and deposited into a pre-weighed $40 \mathrm{ml}$ volatile organic analysis (VOA) vial containing $10 \mathrm{ml}$ of purge and trap grade methanol stored at or below $4{ }^{\circ} \mathrm{C}$. Immediately after sampling, the vials were stored into an ice chest with blue ice. The lexan liner core samples were capped and placed in an ice chest with ice bags. At the end of the day, the VOA vial and core samples were placed into a walk-in cooler at $4^{\circ} \mathrm{C}$. Cores were stored at $4^{\circ} \mathrm{C}$ at all times, except when being processing.

Groundwater Samples - Groundwater samples were collected from a temporary well completion within the boreholes. The temporary well completion consisted of installing a 2-inch PVC liner with a 5-foot screened interval 5 feet below the groundwater table. Sand was backfilled around the screened interval and the wells pumped with a Grundfos Redi-Flo-2 variable speed submersible pump. Each well was purged for several hours until $\mathrm{pH}$, conductivity, and hexavalent chromium concentrations stabilized and turbidity decreased to below 5 NTU. Groundwater samples were collected for VOA, filtered metals, hexavalent chromium, anions, gross alpha and beta, and gamma scans.

\section{C.2 Sample Analysis}

Table C. 1 identifies the number of samples analyzed, the constituents analyzed, analytical methods used, and the laboratory conducting the analysis for the sediment and groundwater samples collected. 
Table C.1. Groundwater and Sediment Analysis Associated with Borehole Installations at the 183-DR Site

\begin{tabular}{|c|c|c|c|c|}
\hline Sample Type & $\begin{array}{c}\text { Number of } \\
\text { Samples }\end{array}$ & $\begin{array}{c}\text { Analytical } \\
\text { Constituents }\end{array}$ & Laboratory & Laboratory Method \\
\hline $\begin{array}{l}\text { Borehole } \\
\text { Sediments }\end{array}$ & 10 & NA & STL & $\begin{array}{l}\text { EPA Method } 1311 \\
\text { TCLP Leaching }\end{array}$ \\
\hline $\begin{array}{l}\text { TCLP } \\
\text { Leachate }\end{array}$ & 10 & Metals & STL & EPA Method 6010 \\
\hline $\begin{array}{l}\text { TCLP } \\
\text { Leachate }\end{array}$ & 10 & Mercury & STL & EPA Method 7470 \\
\hline $\begin{array}{l}\text { TCLP } \\
\text { Leachate }\end{array}$ & 10 & $\begin{array}{l}\text { Volatile } \\
\text { Organics }\end{array}$ & STL & EPA Method 8260 \\
\hline $\begin{array}{l}\text { Borehole } \\
\text { Sediments }\end{array}$ & 66 & $\begin{array}{l}\text { Chromium } \\
\text { (VI) }\end{array}$ & In-House & Hach Method 8023 \\
\hline $\begin{array}{l}\text { Borehole } \\
\text { Sediments }\end{array}$ & 66 & $\mathrm{PH}$ & In-House & Electrometric \\
\hline $\begin{array}{l}\text { Borehole } \\
\text { Sediments }\end{array}$ & 7 & Anions & In-House & PNL Method IC-1 \\
\hline $\begin{array}{l}\text { Borehole } \\
\text { Sediments }\end{array}$ & 10 & $\begin{array}{l}\text { Chromium } \\
\text { (VI) }\end{array}$ & STL & EPA Method 7196 \\
\hline $\begin{array}{l}\text { Borehole } \\
\text { Sediments }\end{array}$ & 10 & Total Metals & KLM & $\begin{array}{c}\text { KLM-XRF } \\
\text { Procedure XRF-1 }\end{array}$ \\
\hline $\begin{array}{l}\text { Borehole } \\
\text { Sediments }\end{array}$ & 4 & Soil VOA & In-House & PNL Method VOA-3 \\
\hline $\begin{array}{l}\text { Borehole } \\
\text { Sediments }\end{array}$ & 10 & $\begin{array}{l}\text { Alpha, Beta, } \\
\text { and Gamma }\end{array}$ & STL & $\begin{array}{l}\text { STL-RC-5014 } \\
\text { STL-RC-5017 }\end{array}$ \\
\hline Groundwater & 2 & $\begin{array}{l}\text { Alpha, Beta, } \\
\text { and Gamma }\end{array}$ & STL & $\begin{array}{l}\text { STL-RC-5014 } \\
\text { STL-RC-5017 }\end{array}$ \\
\hline Groundwater & 2 & Metals & STL & EPA Method 6010 \\
\hline Groundwater & 2 & Anions & In-House & PNL Method IC-1 \\
\hline Groundwater & 2 & VOA & In-House & PNL Method VOA-3 \\
\hline Groundwater & 2 & $\begin{array}{l}\text { Chromium } \\
\text { (VI) }\end{array}$ & STL & EPA Method 7196 \\
\hline \multicolumn{5}{|c|}{$\begin{array}{l}\text { In-House }=\text { Pacific Northwest National Laboratory, Richland, Washington. } \\
\text { KLM }\end{array}$} \\
\hline
\end{tabular}

Upon receipt of the sediment samples in the laboratory, hexavalent chromium analysis was conducted on aliquoted core samples at 2-foot intervals. These samples were leached with a sediment/distilled water ratio of 1:10. Extraction was accelerated with the aid of microwave heating. After cooling the leachate was analyzed for hexavalent chromium according to Hach Method 8023, which is based on EPA 
Method 7196 (EPA 1992). pH was measured on each sample electrometrically. Anions were measured in the leachate solutions from 7 of the leachate samples according to procedure PNL-IC-1. This method is based on EPA Method 300.0 (EPA 1992).

After all sampling was completed from boreholes C3040 and C3041, core segments were selected and prepared for subsequent analysis. Each selected core segment was sieved through a $2 \mathrm{~mm}$ stainless steel sieve. The $<2 \mathrm{~mm}$ sieved fraction was aliquoted into three sub-samples. One $500 \mathrm{ml}$ aliquot was prepared for STL Laboratory for TCLP leaching, chromium(VI), and radiological analysis. In addition, two $60 \mathrm{ml}$ aliquots were also prepared. One aliquot was sent for total metal analysis by x-ray fluorescence. The second 60-ml aliquot was retained as an archive sample for follow up analysis, if necessary.

Groundwater samples were collected in the field following development of the temporary wells. Filtered samples were collected for metals analysis. The remainder of the samples was collected unfiltered. PNNL conducted analysis for anions and volatile organic compounds. Severn Trent Laboratory conducted the remainder of the analysis.

Presented below is a summary of each analytical procedure used for the analysis of sediment and groundwater samples.

Sediment TCLP Leaching: The Toxicity Characteristic Leaching Procedure (TCLP) is a test designed to simulate the leaching a waste will undergo if disposed of in a sanitary landfill. The extraction fluid employed is a function of the alkalinity of the solid phase of the waste. A subsample of a waste is extracted with the appropriate buffered acetic acid solution for $18 \pm 2$ hours, as prescribed in EPA Method 1311 (EPA 1992). A solid/leachate ratio of 1:20 is used for the extraction. The extract obtained from the sediment material is then analyzed to determine if any of the thresholds values established for the 40 Toxicity Characteristic (TC) constituents have been exceeded or if the treatment standards established for the constituents specified by the Land Disposal Restrictions (LDR) program have been met. If the TCLP extract contains any one of the TC constituents in an amount equal to or exceeding the concentrations specified by the LDR program, the waste possesses the characteristic of toxicity and is a hazardous waste. The resulting TCLP extracts in this study were analyzed for RCRA Metals according to EPA Method 6010 (ICAP analysis), volatile organic compounds according to EPA Method 8260, and mercury according to EPA Method 7470. A total of ten sediment samples underwent TCLP leaching and subsequent analysis at Severn Trent Laboratory.

Sediment VOA: Refrigerated methanol preserved VOA samples were allowed to warm to room temperature. The 40-ml vial was centrifuged to settle the particles and a $0.5 \mathrm{ml}$ aliquot was removed and diluted to $40 \mathrm{ml}$ with boiled Mill-Q water in a VOA vial. The sample was then analyzed according to PNL Method VOA-3. PNL Method VOA-3 is based on EPA Method 502.2, which measures a total of 58 volatile and semi-volatile compounds using a tandem photoionization and electrolytic conductivity detector in series. A total of eight samples and two duplicates samples were analyzed from selected core segments at PNNL. 
Sediment X-Ray Fluorescence: A sample aliquot was removed from the core segment and sieved to obtain the $<2 \mathrm{~mm}$ fraction. An aliquot of this fraction was dried at $105^{\circ} \mathrm{C}$, coned and quartered, and ground in a mortar and pestle. A 600-mg sample was analyzed using iron, zirconium, and silver secondary sources according to KLM procedure XRF-1 (KLM 2000). A total of 31 elements were reported for each sample analyzed. KLM Analytical Laboratory, Richland, Washington, analyzed a total of ten samples by XRF corresponding to the same samples submitted to STL for TCLP analysis.

Sediment Chromium (VI): A sample aliquot was removed from the $500 \mathrm{ml}$ aliquoted prepared for STL Laboratory for TCLP leaching. The sample was leached using a 1:10 sediment/distilled water ratio. The samples were analyzed according to EPA Method 7196 as independent verification of PNNL's in-house hexavalent chromium measurement. A total of ten samples corresponding to the same samples submitted for TCLP leaching were analyzed at Severn Trent Laboratory for hexavalent chromium.

Sediment Alpha, Beta, and Gamma: Sediment analysis for alpha, and beta emitting radionuclides were analyzed according to STL's method RC-5014. Sediment samples were digested with nitric acid and the digestates analyzed for alpha and beta radionuclides using appropriate alpha and beta counting techniques. Analysis of gamma emitting radionuclides was conducted according to STL's method RC-5017. Gamma emitting radionuclides were measured directly on aliquots of the sediment samples using high-resolution gamma-ray spectroscopy. A total of ten samples corresponding to the same samples submitted for TCLP leaching were analyzed at Severn Trent Laboratory for alpha, beta, and gamma.

Sediment PCB Screening: Screening of selected sediment samples was conducted using the SDI EnvironGard PCB test kit. This screening test is based on enzyme immunoassay that enables sediment samples to be screened reliably. The test method measures the concentrations of Aroclors 1016, 1242, 1248,1254 , and 1260 to $1 \mathrm{ppm}$ in sediment. Sediment samples are extracted with methanol at a 1:1 soil/methanol volume ratio. An aliquot of the extract is exposed to a treated test tube, which is activated with an enzyme conjugate. The concentration is determined colorimetrically by comparing the absorption of the sample tube to known concentrations of PCBs. A total of ten samples corresponding to the same samples submitted for TCLP leaching were analyzed at PNNL for PCBs.

Groundwater Metals and Radiological Analysis: Groundwater samples were analyzed for filtered metal concentrations according to EPA Method 6010. Analysis of groundwater samples for alpha and beta emitting radionuclides were measured according to STL's method RC-5014. Analysis of gamma emitting radionuclides was conducted according to STL's method RC-5017. A total of two water samples were analyzed at Severn Trent Laboratory.

Groundwater Anions : Groundwater samples were analyzed for fluoride, chloride, bromide, nitrate, phosphate, sulfite, sulfate, formate, and oxalate anions according to PNL Method IC-01. This analysis is based on ion chromatograph separations of anions according to EPA Method 300.0 (EPA 1992). Two groundwater samples were analyzed at PNNL.

Groundwater VOA: Groundwater samples were analyzed for volatile organic compounds according to PNL Method VOA-3. PNL Method VOA-3 is based on EPA Method 502.2 (EPA 1992), which 
measures a total of 58 volatile and semi-volatile compounds using a tandem photoionization and electrolytic conductivity detector in series. Two groundwater samples were analyzed at PNNL.

\section{C.3 Sample Results}

Table C. 2 contains field-screening results for selected C3040 and C3041 borehole sediment samples that were water leached and analyzed for hexavalent chromium, $\mathrm{pH}$, and anion concentrations. Table C.3 contains the results of the TCLP leachate analysis for volatile organic compounds, TCLP RCRA metals, PCBs, total metal concentrations of the sediment samples by XRF for arsenic, chromium, lead, and selenium, and analysis of sele cted sediment samples for hexavalent chromium. Table C.4 contains the groundwater analytical results for anions, alpha, beta, and gamma emitting radionuclides, VOC, and filtered metal concentrations collected from borehole C3040 and C3041.

Reviewing the data present in Table C. 2 revealed no hexavalent chromium to be present in any of the sediment samples. pH ranged from 8.8 to 9.2 in the sediment leachate samples. Anion analysis of selected sediments samples identified the presence of formate and oxala te. Other common anions identified in the leachate solutions included fluoride, chloride, nitrate, phosphate, sulfate, and traces of sulfite identified in one sample.

The TCLP leachate data presented in Table C.3 indicates that no volatile organic compounds were present above the detection limit of the method. This result was expected because of the sample preparation activities involved. In anticipation of this problem, sediment samples were also collected in the field using the methanol preservation method (Liikala et al. 1996). The results of this analysis found trichloroethylene (TCE), chloroform $\left(\mathrm{CCl}_{3} \mathrm{H}\right)$, benzene, toluene, o-xylene, and ethylbenzene present in the samples. In all cases except for chloroform, there was a significant blank proble $m$ within the methanol used to extract the samples. A "B" identifies analyte compounds suspected of have a significant blank contribution. There was a trace of chloroform identified in the methanol but this did not contribute significantly to the high concentrations measured in several samples. The high chloroform concentrations appear to be real. However, if $100 \%$ of the chloroform was extracted into the TCLP leachate solution, its concentrations would only be $1900 \mathrm{ppb}$, significantly below the allowable limit of $6,000 \mathrm{ppb}$ for the TCLP leachate solutions.

Results of the RCRA metals analysis of the TCLP leachate solutions found all the target metals below the TCLP action levels. The results of the XRF analysis found total arsenic and selenium at or below the detection limit of the method. Total chromium and lead concentrations were observed at typical Hanford background concentrations for sediment samples with the exception of $132.8 \mathrm{ppm}$ chromium found in sample C3040 68-68.5. This sample also had $130 \mathrm{ppb}$ of leachable hexavalent chromium. All other hexavalent chromium concentrations were below the method detection limit.

Results of radiochemical analysis on the sediments found normal Hanford background activities. Total alpha activity ranged from below the method detection limit to $11 \mathrm{pCi} / \mathrm{g}$. Beta activity ranges from 12.9 to $31.9 \mathrm{pCi} / \mathrm{g}$. All the cobalt -60 and cesium- 137 concentrations were below the method detection limits. Potassium-40 ranged from $10.1 \mathrm{pCi} / \mathrm{g}$ to $21.9 \mathrm{pCi} / \mathrm{g}$, which is normal for Hanford sediments. 
Table C.2. Chromium (VI), pH, and Anion Results for Water Leachates of Sediment Samples Collected from Boreholes C3040 and C3041

\begin{tabular}{|c|c|c|c|c|c|c|c|c|c|c|c|c|}
\hline Sample ID & Depth (ft) & $\begin{array}{c}\text { Sediment } \\
{[\mathrm{Cr}+6]} \\
(\mathrm{ppm})\end{array}$ & $\mathrm{pH}$ & $\begin{array}{c}\text { Fluoride } \\
\text { (ppm) }\end{array}$ & $\begin{array}{c}\text { Chloride } \\
\text { (ppm) }\end{array}$ & $\begin{array}{c}\text { Bromide } \\
\text { (ppm) }\end{array}$ & $\begin{array}{l}\text { Nitrate } \\
\text { (ppm) }\end{array}$ & $\begin{array}{c}\text { Phosphate } \\
\text { (ppm) }\end{array}$ & $\begin{array}{l}\text { Sulfite } \\
\text { (ppm) }\end{array}$ & $\begin{array}{l}\text { Sulfate } \\
\text { (ppm) }\end{array}$ & $\begin{array}{c}\text { Formate } \\
\text { (ppm) }\end{array}$ & $\begin{array}{c}\text { Oxalate } \\
\text { (ppm) }\end{array}$ \\
\hline C3040 & 24.5 & 0.00 & 9.1 & 2.5 & 11.3 & 0.2 & 7.5 & 0.3 & nd & 59 & 2.4 & 10.6 \\
\hline C3040 & 24.5dup & 0.00 & 9.1 & & & & & & & & & \\
\hline С3040 & $26.5-27$ & 0.00 & 8.9 & & & & & & & & & \\
\hline C3040 & $29-29.5$ & 0.00 & 9.1 & & & & & & & & & \\
\hline C3040 & $31.5-32$ & 0.00 & 9.0 & & & & & & & & & \\
\hline C3040 & $32-33$ & 0.00 & 9.0 & & & & & & & & & \\
\hline С3040 & $34-35.1$ & 0.00 & 9.1 & & & & & & & & & \\
\hline С3040 & $35.5-36.8$ & 0.00 & 9.0 & & & & & & & & & \\
\hline C3040 & $39-39.5$ & 0.00 & 9.1 & & & & & & & & & \\
\hline C3040 & $40.5-41$ & 0.00 & 9.1 & & & & & & & & & \\
\hline С3040 & $42-42.5$ & 0.00 & 9.1 & & & & & & & & & \\
\hline C3040 & $44-44.5$ & 0.00 & 9.0 & 0.8 & 10.4 & $<0.05$ & 5.2 & $<0.05$ & $<0.05$ & 16 & 1.2 & 3.7 \\
\hline C3040 & $46.5-47$ & 0.00 & 9.0 & & & & & & & & & \\
\hline C3040 & $48-48.5$ & 0.00 & 8.9 & & & & & & & & & \\
\hline C3040 & 48-48.5dup & 0.00 & 8.8 & & & & & & & & & \\
\hline C3040 & $50-50.5$ & 0.00 & 9.0 & & & & & & & & & \\
\hline C3040 & $52-52.5$ & 0.00 & 9.0 & & & & & & & & & \\
\hline C3040 & $54-54.5$ & 0.00 & 9.0 & & & & & & & & & \\
\hline С3040 & $56.5-57$ & 0.00 & 8.9 & & & & & & & & & \\
\hline C3040 & $58-58.5$ & 0.00 & 9.0 & & & & & & & & & \\
\hline C3040 & $60-60.5$ & 0.00 & 9.0 & & & & & & & & & \\
\hline С3040 & 62-62.5 & 0.00 & 8.9 & & & & & & & & & \\
\hline C3040 & 62-62.5dup & 0.00 & 9.0 & & & & & & & & & \\
\hline C3040 & $64.5-65$ & 0.00 & 9.1 & 1.2 & 14.1 & $<0.05$ & 3 & $<0.05$ & $<0.05$ & 22.7 & 0.9 & 0.4 \\
\hline C3040 & 64.5-65dup & 0.00 & 8.9 & & & & & & & & & \\
\hline C3040 & 66.5-67 & 0.00 & 8.8 & & & & & & & & & \\
\hline С3040 & $68-68.5$ & 0.00 & 8.8 & & & & & & & & & \\
\hline C3040 & $70.5-71$ & 0.00 & 8.8 & & & & & & & & & \\
\hline C3040 & $72-72.5$ & 0.00 & 8.8 & & & & & & & & & \\
\hline С3040 & $74-74.5$ & 0.00 & 8.8 & & & & & & & & & \\
\hline С3040 & $75.5-76$ & 0.00 & 8.8 & & & & & & & & & \\
\hline C3040 & $77.5-78$ & 0.00 & 8.8 & & & & & & & & & \\
\hline C3040 & $79-79.5$ & 0.00 & 8.8 & & & & & & & & & \\
\hline C3040 & $80.5-81$ & 0.00 & 8.9 & 0.16 & 1.12 & $<0.05$ & 0.45 & $<0.05$ & 0.03 & 3.42 & 0.1 & 0.03 \\
\hline C3040 & $82.5-83$ & 0.00 & 9.2 & & & & & & & & & \\
\hline C3040 & 86 & 0.00 & 9.3 & & & & & & & & & \\
\hline C3040 & $88-87.5$ & 0.00 & 8.9 & & & & & & & & & \\
\hline C3040 & $88.5-90$ & 0.00 & 9.1 & & & & & & & & & \\
\hline C3041 & 10-AR & 0.00 & 9.2 & & & & & & & & & \\
\hline C3041 & 15-AR & 0.00 & 9.2 & & & & & & & & & \\
\hline С3041 & 20-AR & 0.00 & 9.0 & & & & & & & & & \\
\hline C3041 & 20 & 0.00 & 8.9 & & & & & & & & & \\
\hline C3041 & 25 & 0.00 & 8.9 & & & & & & & & & \\
\hline С3041 & 25dup & 0.00 & 8.9 & & & & & & & & & \\
\hline C3041 & $27-27.5$ & 0.00 & 8.9 & & & & & & & & & \\
\hline C3041 & $29.5-30.5$ & 0.00 & 9.0 & & & & & & & & & \\
\hline C3041 & $32-33$ & 0.00 & 8.9 & & & & & & & & & \\
\hline C3041 & $35-35.5$ & 0.00 & 9.0 & & & & & & & & & \\
\hline C3041 & $34-34.5$ & 0.00 & 9.0 & & & & & & & & & \\
\hline C3041 & $36.5-37.5$ & 0.00 & 9.0 & & & & & & & & & \\
\hline C3041 & $39-40$ & 0.00 & 9.0 & & & & & & & & & \\
\hline C3041 & 39-40dup & 0.00 & 9.0 & & & & & & & & & \\
\hline C3041 & $41.5-42.5$ & 0.00 & 9.0 & 0.7 & 6.3 & $<0.05$ & 3.5 & 0.6 & $<0.05$ & 9.1 & 0.3 & nd \\
\hline C3041 & $44-45$ & 0.00 & 9.0 & & & & & & & & & \\
\hline C3041 & $46.5-47.5$ & 0.00 & 9.1 & & & & & & & & & \\
\hline C3041 & $49-50$ & 0.00 & 9.1 & & & & & & & & & \\
\hline С3041 & $51.5-52.5$ & 0.00 & 9.1 & & & & & & & & & \\
\hline C3041 & $54-55$ & 0.00 & 9.3 & & & & & & & & & \\
\hline C3041 & $56.5-57.5$ & 0.00 & 9.0 & & & & & & & & & \\
\hline C3041 & $58-59$ & 0.00 & 9.0 & & & & & & & & & \\
\hline C3041 & $61.5-62.5$ & 0.00 & 9.0 & 1.4 & 6.7 & $<0.05$ & 2.7 & 0.8 & $<0.05$ & 11.7 & 0.7 & 0.4 \\
\hline C3041 & $71-72$ & 0.00 & 9.0 & & & & & & & & & \\
\hline C3041 & $73.5-74.5$ & 0.00 & 8.9 & & & & & & & & & \\
\hline C3041 & $73.5-74.5$ & 0.00 & 8.8 & & & & & & & & & \\
\hline С3041 & 77-78 & 0.00 & 9.1 & 1.3 & 18.8 & $<0.05$ & 3.2 & 0.7 & $<0.05$ & 8.8 & 4.3 & 0.2 \\
\hline C3041 & $79.5-80.5$ & 0.00 & 8.8 & & & & & & & & & \\
\hline C3041 & 82-83 & 0.00 & 8.9 & & & & & & & & & \\
\hline
\end{tabular}


Table C.3. Analytical Results for Sediment Samples Collected from 183-DR Boreholes C3040 and C3041

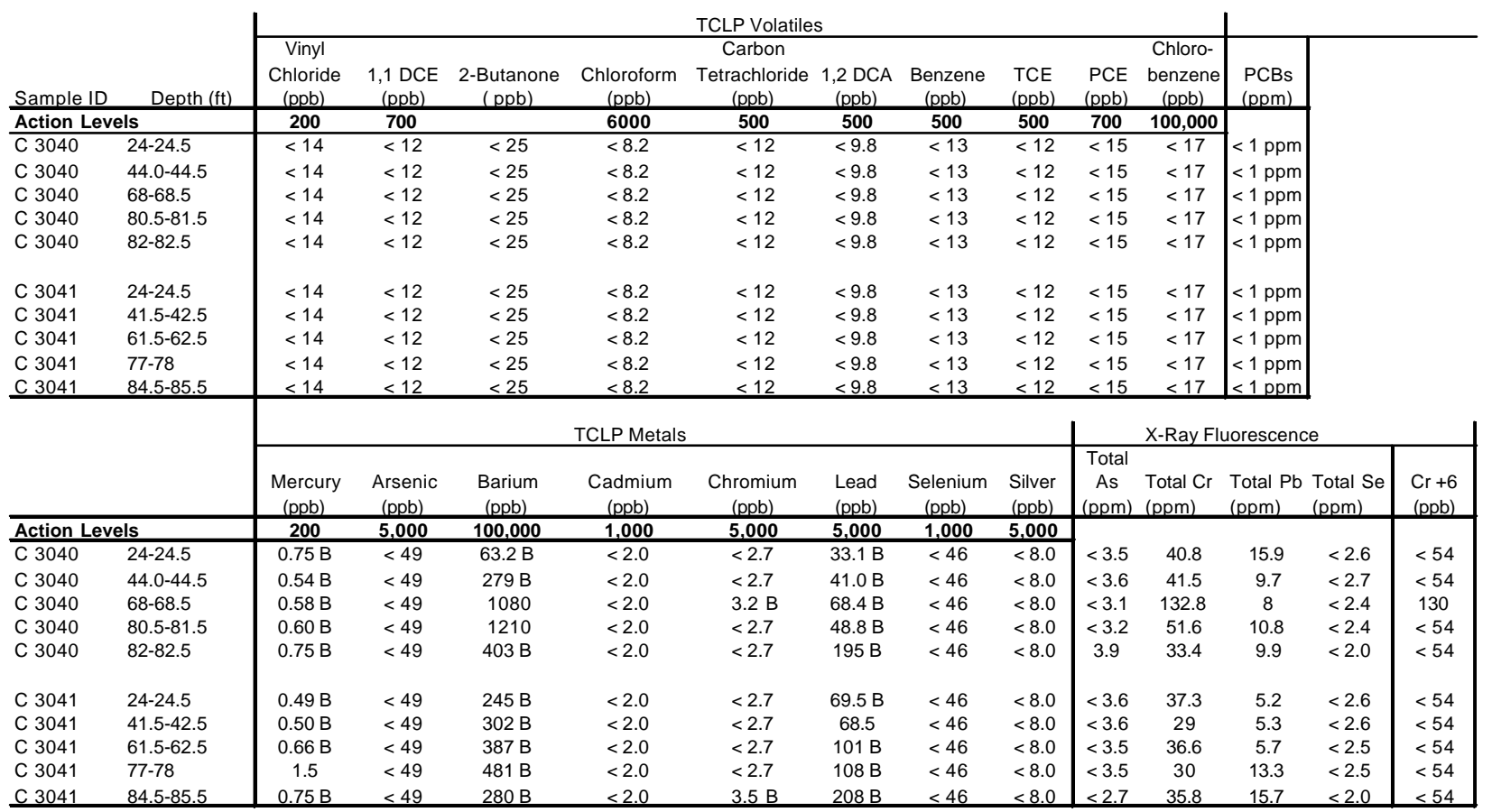

TCE = Trichloroethylene

PCE $=$ Tetrachloroethylene

$1,1 \mathrm{DCE}=1,1$ Dichloroethyene

1,2 DCA = 1,2 Dichloroethane

$\mathrm{B}=$ Target Analyte found in blank

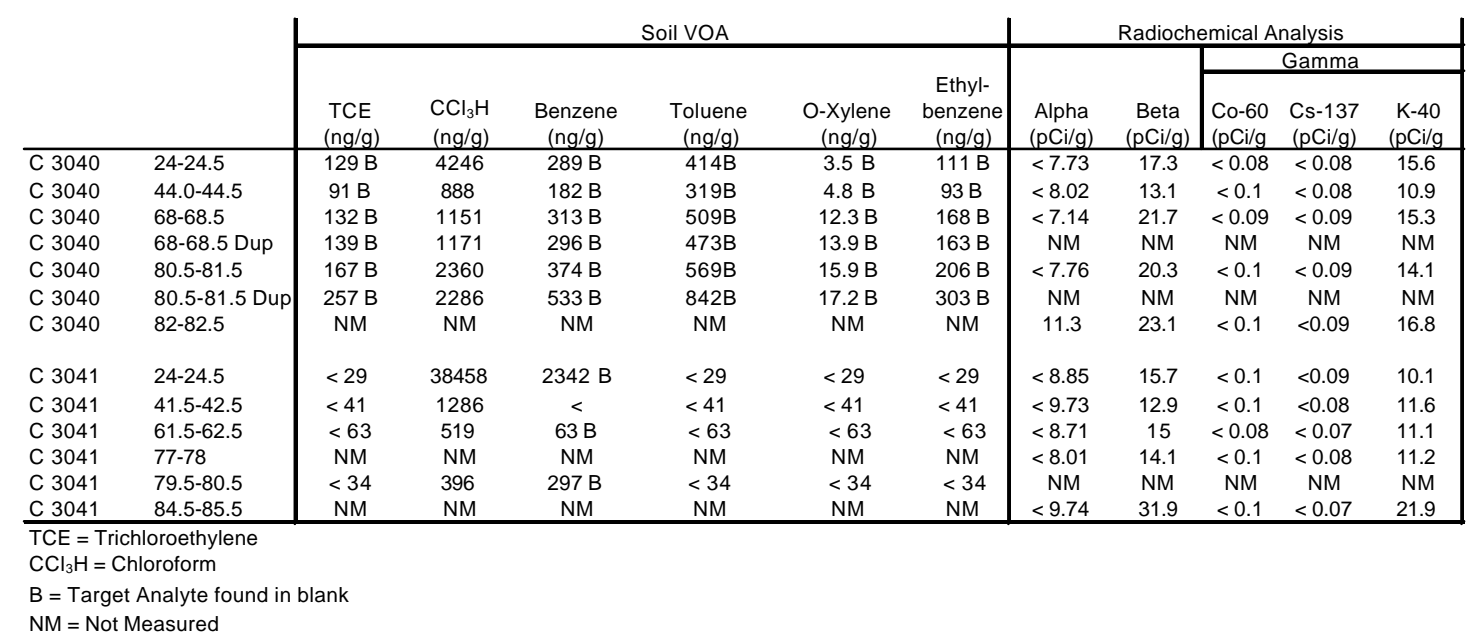

C.7 
Table C.4. Results for Groundwater Samples Collected from 183-DR Boreholes C3040 and C3041

\begin{tabular}{|c|c|c|c|c|c|c|c|c|c|c|c|c|c|c|}
\hline & & & & & Anions & & & & & & & \multicolumn{3}{|c|}{ Gamma } \\
\hline Sample & \begin{tabular}{|c}
$\begin{array}{c}\text { Fluoride } \\
\text { (ppm) }\end{array}$ \\
\end{tabular} & $\begin{array}{c}\begin{array}{c}\text { Chloride } \\
\text { (ppm) }\end{array} \\
\end{array}$ & $\begin{array}{c}\text { Bromide } \\
\text { (ppm) }\end{array}$ & $\begin{array}{l}\text { Nitrate } \\
(\mathrm{ppm})\end{array}$ & $\begin{array}{c}\text { Phosphate } \\
\text { (ppm) }\end{array}$ & $\begin{array}{l}\text { Sulfite } \\
(\mathrm{ppm})\end{array}$ & $\begin{array}{l}\text { Sulfate } \\
(\mathrm{ppm})\end{array}$ & $\begin{array}{c}\begin{array}{c}\text { Formate } \\
(\mathrm{ppm})\end{array} \\
\end{array}$ & $\begin{array}{c}\begin{array}{c}\text { Oxalate } \\
(\mathrm{ppm})\end{array} \\
\end{array}$ & $\begin{array}{l}\text { Alpha } \\
\text { (pCi/L) }\end{array}$ & $\begin{array}{r}\text { Beta } \\
(\mathrm{pCi} / \mathrm{L})\end{array}$ & $\begin{array}{l}\mathrm{Co}-60 \\
\text { (pCi/L) }\end{array}$ & $\begin{array}{l}\mathrm{Cs}-137 \\
(\mathrm{pCi} / \mathrm{L})\end{array}$ & $\begin{array}{c}\mathrm{K}-40 \\
(\mathrm{pCi} / \mathrm{L})\end{array}$ \\
\hline C3040 & 0.1 & 12.5 & 0.12 & 48.7 & 0.03 & nd & 113 & nd & nd & 2.88 & 5.77 & $<3.28$ & $<4.16$ & $<91$ \\
\hline C3041 & 0.12 & 11.3 & 0.11 & 46.4 & 0.02 & nd & 95.9 & 0.01 & nd & 4.16 & 7.38 & $<5.58$ & $<5.18$ & $<130$ \\
\hline & \multicolumn{14}{|c|}{ Filtered Metals } \\
\hline Sample & $\begin{array}{c}\mathrm{Hg} \\
(\mathrm{ppb})\end{array}$ & $\begin{array}{c}\mathrm{Al} \\
(\mathrm{ppb})\end{array}$ & $\begin{array}{c}\mathrm{Sb} \\
(\mathrm{ppb})\end{array}$ & $\mathrm{Ba}(\mathrm{ppb})$ & $\mathrm{Be}(\mathrm{ppb})$ & $\mathrm{Cd}(\mathrm{ppb})$ & $\begin{array}{c}\mathrm{Ca} \\
(\mathrm{ppm})\end{array}$ & $\mathrm{Cr}+6$ & $\mathrm{Cr}(\mathrm{ppb})$ & $\begin{array}{c}\text { Co } \\
(\mathrm{ppb})\end{array}$ & $\begin{array}{c}\mathrm{Cu} \\
(\mathrm{ppb})\end{array}$ & $\begin{array}{c}\mathrm{Fe} \\
(\mathrm{ppb})\end{array}$ & $\begin{array}{c}\mathrm{Mg} \\
(\mathrm{ppm})\end{array}$ & $\begin{array}{c}\mathrm{Mn} \\
\text { (ppb) }\end{array}$ \\
\hline C 3040 & $<0.20$ & $181 \mathrm{~B}$ & $<39$ & $67.9 \mathrm{~B}$ & $<0.6$ & $<2.8$ & 76.7 & 1490 & 1600 & $<4.6$ & $<6.4$ & 269 & 18.4 & 65.5 \\
\hline C 3041 & $<0.20$ & 2500 & $<39$ & 103 & $<0.6$ & $<2.8$ & 71.6 & 87 & 93.7 & $6.5 \mathrm{~B}$ & $<6.4$ & 3950 & 17.3 & 184 \\
\hline & \multicolumn{7}{|c|}{ Filtered Metals } & Volatiles & Organics & & & & & \\
\hline Sample & $\mathrm{Ni}(\mathrm{ppb})$ & $\mathrm{K}(\mathrm{ppm})$ & $\mathrm{Ag}(\mathrm{ppb})$ & $\begin{array}{c}\mathrm{Na} \\
(\mathrm{ppm}) \\
\end{array}$ & $\operatorname{Sr}(p p b)$ & $V(p p b)$ & $\mathrm{Zn}(\mathrm{ppb})$ & \begin{tabular}{|c|}
$\mathrm{CCl}_{3} \mathrm{H}$ \\
$(\mathrm{ppb})$
\end{tabular} & \begin{tabular}{|c|c}
$\begin{array}{c}\text { Benzene } \\
(\mathrm{ppb})\end{array}$ \\
\end{tabular} & & & & & \\
\hline C 3040 & $<13.3$ & 5.7 & $<7.4$ & 10.4 & 441 & $12.5 \mathrm{~B}$ & $<4.2$ & 9.33 & 0.05 & & & & & \\
\hline C 3041 & $15.6 \mathrm{~B}$ & 7.8 & $<7.4$ & 13.7 & 417 & $17.3 \mathrm{~B}$ & $10.3 \mathrm{~B}$ & 1.01 & $<0.05$ & & & & & \\
\hline
\end{tabular}

Reviewing the groundwater data presented in Table C.4 indicates elevated nitrate and background concentrations of the other common anions. Total alpha and beta activity were at background levels for the Hanford Site. Cobalt-60, cesium-137, and potassium-40 were all below the method detection limits. Results from filtered metals analysis found elevated chromium in the groundwater from C3040 and slightly elevated chromium in groundwater from C3041. The hexavalent chromium concentrations measured in the groundwater from both wells strongly suggest most if not all of the chromium measured by EPA Method 6010 was hexavalent chromium. Comparing the aluminum, iron, and manganese results from both groundwater samples suggest there may have been some fine particulate matter (sediment) present in the sample from C3041. Those aforementioned elements were significantly higher in C3041. Of the 58 volatile and semi-volatile compounds measured in two groundwater samples only chloroform and a trace of benzene were found in the samples.

\section{C.4 References}

KLM. 2000. Energy Dispersive X-Ray Fluoresence Spectroscopy Using the BFP Approach with the Kevex 0810A System. KLM Procedure XRF (PNL-AL0-266), KLM Analytical Laboratory, Richland, Washington.

Liikala, T.L., K.B. Olsen, S.S. Teel, and D.C. Lanigan. 1996. "Volatile Organic Compounds:

Comparison of Two Sample Collection and Preservation Methods." Environ. Sci. Technol. 30, 3441.

Thornton, E.C., K.J. Cantrell, J.M. Faurote, T.J Gilmore, K.B. Olsen, and R. Schalla. 2000.

Identification of a Hanford Waste Site for Initial Deployment of the In Situ Gaseous Reduction Approach. PNNL-13107, Pacific Northwest National Laboratory, Richland, Washington.

U.S. Environmental Protection Agency (EPA). 1992. Test Methods for Evaluating Solid Waste Physical/Chemical Methods, $3^{\text {rd }}$ ed. SW-846. U.S. Environmental Protection Agency, Washington, D.C. 


\section{Distribution}

No. of

Copies

OFFSITE

3 U.S. Department of Energy

Savannah River Operations Office

P.O. Box A

Aiken, SC 29802

ATTN: T. Hicks

S. R. McMullin

J. A. Wright

\section{ONSITE}

4 DOE Richland Operations Office

G. I. Goldberg

J. P. Hanson

K. M. Thompson

A. C. Tortoso

5 Bechtel Hanford, Inc.

K. R. Fecht

R. L. Jackson

G. B. Mitchem

S. W. Petersen

V. J. Rohay

\section{CH2M HILL Hanford Group}

M. H. Sturges

C. C. Swanson
No. of

Copies

Flour Federal Services

R. Khaleel

B4-43

\section{Pacific Northwest National Laboratory}

W. F. Bonner

K9-14

J. G. Bush

K6-96

R. J. Cameron

K6-96

K. J. Cantrell

K6-81

J. L. Devary

K6-96

M. D. Freshley

H0-21

M. W. Fullmer

P7-28

J. S. Fruchter

K6-96

T. J Gilmore

K6-81

M. J. Hartman

K6-96

D. G. Horton

K6-81

G. V. Last

K6-81

W. J. Martin

K6-81

C. A. Newbill

K6-96

K. B. Olsen

K6-96

M. Oostrom

K9-33

R. Peterson

K6-96

R. Schalla

K6-96

R. M. Smith

K6-96

F. A. Spane

E. C. Thornton (15)

K6-96

K6-96

B. A. Williams

K6-81

M. D. Williams

K9-36

Hanford Technical Library (2)

P8-55 